NBER WORKING PAPER SERIES

\title{
DO TAX INCENTIVES FOR RESEARCH INCREASE FIRM INNOVATION? AN RD DESIGN FOR R\&D
}

\author{
Antoine Dechezleprêtre \\ Elias Einiö \\ Ralf Martin \\ Kieu-Trang Nguyen \\ John Van Reenen \\ Working Paper 22405 \\ http://www.nber.org/papers/w22405
}

\author{
NATIONAL BUREAU OF ECONOMIC RESEARCH \\ 1050 Massachusetts Avenue \\ Cambridge, MA 02138 \\ July 2016
}

The HMRC Datalab has helped immeasurably with this paper, although only the authors are responsible for contents. We would like to thank Steve Bond, Mike Devereux, Irem Gucerci, Bronwyn Hall, Pierre Mohnen and Reinhilde Veugelers for helpful comments. Participants in seminars at BIS, HM Treasury, Munich, Oxford and LSE have all contributed to improving the paper. Financial support from the Economic and Social Research Council through the Centre for Economic Performance and the Centre for Climate Change Economics and Policy is gratefully acknowledged. A.D. also acknowledges financial support from the Grantham Foundation for the Protection of the Environment. The views expressed herein are those of the authors and do not necessarily reflect the views of the National Bureau of Economic Research.

NBER working papers are circulated for discussion and comment purposes. They have not been peer-reviewed or been subject to the review by the NBER Board of Directors that accompanies official NBER publications.

(C) 2016 by Antoine Dechezleprêtre, Elias Einiö, Ralf Martin, Kieu-Trang Nguyen, and John Van Reenen. All rights reserved. Short sections of text, not to exceed two paragraphs, may be quoted without explicit permission provided that full credit, including $\odot$ notice, is given to the source. 
Do tax Incentives for Research Increase Firm Innovation? An RD Design for R\&D

Antoine Dechezleprêtre, Elias Einiö, Ralf Martin, Kieu-Trang Nguyen, and John Van Reenen NBER Working Paper No. 22405

July 2016

JEL No. O31

\begin{abstract}
We present evidence of a causal impact of research and development (R\&D) tax incentives on innovation. We exploit a change in the asset-based size thresholds for eligibility for $R \& D$ tax subsidies and implement a Regression Discontinuity Design using administrative tax data on the population of UK firms. There are statistically and economically significant effects of the tax change on both R\&D and patenting (even when quality-adjusted). R\&D tax price elasticities are large at about 2.6, probably because the treated group is from a sub-population of smaller firms and subject to financial constraints. There does not appear to be pre-policy manipulation of assets around the thresholds that could undermine our design. Over the 2006-11 period aggregate business R\&D would be around 10\% lower in the absence of the tax relief scheme. We also show that the R\&D generated by the tax policy creates positive spillovers on the innovations of techno-logically related firms.
\end{abstract}

Antoine Dechezleprêtre

Grantham Research Institute on

Climate Change and the Environment \&

Centre for Economic Performance

London School of Economics

Houghton Street

London WC2A $2 \mathrm{AE}$

United Kingdom

A.Dechezlepretre@1se.ac.uk

Elias Einiö

London School of Economics

\& Political Science (LSE)

Houghton Street

London, WC2A $2 \mathrm{AE}$

United Kingdom

e.einio@1se.ac.uk
Kieu-Trang Nguyen

Center for Economic Performance

London School of Economics

42 Houghton Street

WC2A 2AE London

United Kingdom

trang.kieu.nguyen@gmail.com

John Van Reenen

Department of Economics

London School of Economics

Centre for Economic Performance

Houghton Street

London WC2A 2AE

UNITED KINGDOM

and NBER

j.vanreenen@1se.ac.uk

Ralf Martin

Imperial College Business School

London School of Economics

London SW7 2AZ

United Kingdom

and Centre for Economic Performance, LSE

r.martin@imperial.ac.uk 


\section{Introduction}

Innovation is recognized as the major source of growth in modern economies. But because of knowledge externalities, private returns on research and development (R\&D) are lower than their social returns, hence the need for some public subsidy. ${ }^{1}$ As a consequence, almost every country treats R\&D investments more generously than capital investment, but the majority of OECD countries (and many developing countries) also have additional fiscal incentives such as enhanced deductions for R\&D. Over the last two decades, these tax incentives have grown more popular compared to more direct R\&D subsidies to firms. ${ }^{2}$ One reason for this shift is that subsidizing R\&D through the tax system rather than direct grants reduces administrative burden and mitigates the risk of "picking losers" (e.g. choosing firms with low private and social returns due to political connections).

But do R\&D tax incentives actually work? The existing literature has several serious shortcomings that we seek to address in this paper. First, researchers have mainly focused on the effects of taxes on $R \& D$ whereas the point of the policy is to try and stimulate innovation. ${ }^{3}$ The tax incentive could increase observed $R \& D$ without having much effect on innovation if, for example, firms re-labeled existing activities as $R \& D$ to take advantage of the tax credits or only expanded very low quality $R \& D$ projects. We address this issue by analyzing the effect of $R \& D$ tax incentives not only on R\&D expenditures but also on patenting activity (and other firm performance measures such as TFP and size). We also look at the quality of these additional innovations through various commonly used measures of patent value.

A second problem with the literature is that it has proven difficult to come up with compelling causal designs to evaluate the impact of R\&D tax policies. Evaluations at the macro-economic (e.g. Bloom, Griffith and Van Reenen, 2002; Corrado et al., 2015) or state level (e.g. Wilson, 2009; Moretti and Wilson, 2015) face the problem that changes of policies are likely to be coincident

\footnotetext{
${ }^{1}$ Typical results find marginal social rates of return to R\&D between $30 \%$ and $50 \%$ compared to private returns between from 7\% to 15\% (Hall, Mairesse and Mohnen, 2010). Endogenous growth theories (Romer 1990, Aghion and Howitt 1992) provide several reasons why private innovative activities do not take into account externalities over producers and consumers, and produce less than optimal innovations and growth. For evidence showing R\&D externalities, see for example Bloom, Schankerman and Van Reenen (2013). There is also evidence that these spillovers are partially localized geographically, so the country where the R\&D is performed obtains a disproportionate share of the productivity benefits, at least initially (Jaffe, Trajtenberg and Henderson, 1993).

${ }^{2}$ Over the period 2001-2011, R\&D tax incentives were expanded in 19 out of 27 OECD countries (OECD 2014).

${ }^{3}$ There is a large literature on the effects of public R\&D grants on firm and industry outcomes such as Einiö (2014), González, Jamandreu and Pazó (2005), Goodridge et al. (2015), Jaffe and Le (2015), Lach (2002), Moretti, Steinwender and Van Reenen (2015) and Takalo, Tanayama, Toivanen (2013). The earlier literature is surveyed in David, Hall and Toole (2000).
} 
with many unobserved factors that may influence $R \& D$. On the other hand, variation at the firm level is often limited as the tax rules apply to all firms and the heterogeneity in tax prices that does exist are driven by endogenous firm choices (e.g. R\&D spending, tax exhaustion, etc.).

To address this identification problem, we exploit a policy reform in the UK which raised the size threshold under which firms can access the more generous tax regime for small- and mediumsized enterprises (SME). Importantly, the new tax threshold introduced was unique to the R\&D tax policy so it did not overlap with access to other programs or taxes. Prior to the major change in 2008 the threshold was based on the European Commission definition of an SME. Given this change in tax thresholds, we can implement a Regression Discontinuity (RD) Design (e.g. Lee and Lemieux 2010) looking at differences in R\&D and innovation around the new SME threshold, which was based on accounting data pre-dating the policy change. To assess the validity of our design we confirm covariate balance and the absence of bunching of the running variable (assets) around the threshold prior to the policy change. And we can show that there were no discontinuities in $R \& D$, patents or any other outcomes in the years prior to the policy change.

A third problem with the literature is that data limitations have meant a focus on large firms. Since R\&D is concentrated, aggregated data will also be effectively dominated by large firms. Accounting regulations in most countries only require larger (usually public listed) firms to report R\&D. As a consequence there has been a particular focus on US Compustat firms. ${ }^{4}$ But since at least Arrow (1962) it has been recognized that financial markets may under-supply credit for R\&D and these problems are likely to be particularly acute for SMEs. ${ }^{5}$ Hence, extrapolating from the innovation response of large firms to policy changes may be misleading. We use a new merged dataset containing the universe of UK firms. This combines confidential HMRC data (the UK equivalent of the US IRS) on R\&D levels, firm accounts from the population of public and private firms, and patents from 60 patent offices around the world. The data is available before and after the $R \& D$ tax change.

We find large effects of the R\&D Tax Scheme on R\&D and patents. As a result of the policy, R\&D approximately doubled in the treated firms and patenting rose by about $60 \%$ (and there is no

\footnotetext{
${ }^{4}$ Rao (2015) has used US administrative tax data on the firm population to look at the impact of tax credits on R\&D and Agrawal, Rosell and Simcoe (2014) look at the tax effect on investment for small private Canadian firms.

${ }^{5}$ Since R\&D costs are mainly people such as scientists, it is hard to post collateral to borrow against R\&D projects. Furthermore, asking outsiders for finance may reveal the innovation and so undermine its value.
} 
evidence that these innovations were of lower value). We estimate an elasticity of R\&D with respect to its tax-adjusted user cost of about 2.6- higher than the values typical in the recent literature of between one and two. ${ }^{6}$ We argue that the higher elasticity is likely to be because the sub-population "randomized in" by the RD Design is composed of smaller firms than have usually been examined and so are more likely to be credit constrained and therefore are also more responsive to $R \& D$ tax credits. We confirm this intuition by showing the response is particularly strong for young firms, presumably because they are more subject to credit constraints. Our simple calculations suggest that between 2006 and 2011 the UK R\&D Tax Relief Scheme induces $£ 1.7$ of private R\&D for every $£ 1$ of taxpayer money and that aggregate UK business R\&D would have been about $10 \%$ lower in the absence of the policy. Finally, we find evidence that the R\&D induced by the tax policy generated spillovers - i.e. more innovation by technologically related firms. Hence, it appears the policy succeeded in its intentions.

In terms of the existing literature, some papers have examined the causal impact of other types of innovation policy on R\&D and other outcomes. These have used ratings given to grant applications as a way of generating exogenous variation around funding thresholds. Jacob and Lefgren (2010) and Azoulay et al. (2014) examine the impact of NIH grants. Bronzini and Iachini (2014) and Bronzini and Piselli (2014) use an RD Design for R\&D subsidies in Italy. ${ }^{7}$ Probably closest to our paper is Howell (2015) who uses the ranking of SBIR proposals for energy R\&D. She finds significant effects of subsidies on future venture capital funding, especially for small firms. ${ }^{8}$ Some papers have looked at the impact of R\&D tax credits on non-R\&D outcomes without an RD Design. For example, Bøler, Moxnes and Ulltveit-Moe (2015) employ a difference-in-differences strategy to investigate how the introduction of R\&D tax credit in Norway affects profits, intermediate imports and R\&D. ${ }^{9}$

Our paper also contributes to the literature on the effects of R\&D on innovation (e.g. Hall, Mairesse, and Mohnen, 2010). We find that R\&D has a positive causal effect on innovation, with elasticities that are underestimated in conventional OLS approaches. More broadly, we provide

\footnotetext{
${ }^{6}$ See surveys by Becker (2015), OECD (2013) or Hall and Van Reenen (2000).

${ }^{7}$ The authors look at the impacts of R\&D subsidies on investment and patents in Northern Italy in an RD Design (they do not have R\&D data). In their setting the running variable is determined on the basis of scoring the project applications by a committee of experts. They observe a discontinuity in the score distribution around the eligibility cut-off, which they interpret as a sign of program managers being able to assign higher scores for projects just below the cutoff to avoid appeals.

${ }^{8}$ She also finds effects on patents, but not on citations from Phase 1 funding.

${ }^{9}$ See also Czarnitki, Hanel, and Rosa (2011), Cappelen, Raknerud, and Rybalka (2012) and Bérubé and Mohnen (2009) who look at the effects of R\&D tax credits on patents and/or new products. Branstetter and Sakakibara (2002) examine Research Joint Ventures and patents.
} 
evidence on the role of tax on a particular kind of investment (Hall and Jorgenson, 1967; Hassett and Hubbard, 2002).

The paper is organized as follows. Section 2 details the institutional setting; Section 3 explains the empirical design; Section 4 describes the data; Section 5 presents the main results; Section 6 some extensions; Section 7 has the technology spillover analysis and Section 8 concludes.

\section{Institutional setting}

We give more details of the institutional setting and tax policies in Appendix A (e.g. Table A1 details the policy changes over time), but summarize the most important features in this section. From the early 1980s the UK business R\&D to GDP ratio fell, whereas it rose in most other OECD countries. In 2000, an R\&D Tax Relief Scheme was introduced for small and medium enterprises (SMEs). It was extended to cover large companies in 2002, but SMEs continued to enjoy more generous R\&D tax relief. The policy costs the UK government £1.4bn in 2013 alone (Fowkes, Sousa and Duncan, 2015).

The tax policy is based on the total amount of R\&D, i.e. it is volume-based rather than calculated as an increment over past spending like the US R\&D tax credit. It works mostly through enhanced deduction of R\&D from taxable income, thus reducing corporate tax liabilities. ${ }^{10}$ At the time of its introduction, the scheme allowed SMEs to deduct an additional enhancement rate of $50 \%$ of qualifying R\&D expenditure from taxable profits (on top of the $100 \%$ deduction that applies to any form of current expenditure). If an SME was not making profits, it could surrender enhanced losses in return for a payable tax credit $^{11}$ amounting to $16 \%$ of enhanced R\&D. ${ }^{12}$ This design feature was aimed at dealing with the well-known problem that smaller companies may not be making enough profits to benefit from the enhancement rate. The refundable aspect of the scheme is particularly beneficial to firms who are liquidity constrained and we will present evidence in line with the idea that the large responses we observe are related to the alleviation of financial constraints. Large companies had a less generous deduction rate of $25 \%$ of their R\&D and could not claim the refundable tax credits in the case of losses (Finance Act, 2002).

The aggregate UK business R\&D to GDP ratio stabilized after the introduction of this $R \& D$ tax policy and Bond and Guceri (2012) suggest that these are causally connected. Guceri (2015)

\footnotetext{
${ }^{10}$ Only current R\&D expenditures, such as labor and materials, qualify for the scheme, but since capital only accounts for about $10 \%$ of total R\&D, this is less important (e.g. Cameron, 1996).

${ }^{11}$ Throughout we will use "tax credit" to refer to this refundable element of the scheme as distinct from the "enhancement" element.

${ }^{12}$ Or equivalently, 24\% (=16\% x 150\%) of total R\&D expenditure. See Finance Act 2000 (Chapter 17, Schedule 20).
} 
uses a difference-in-differences method across firm size classes to look at the effect of the introduction of the program and argues that the policy raised R\&D by a fifth in the affected firms. Fowkes et al. (2015) calculate the firm-specific user cost and instrument this with lagged values, also finding positive effects on R\&D.

The policy used the SME definition recommended by the European Commission (EC) throughout most of the 2000s. This definition was based on employment, total assets, and sales ${ }^{13}$ from the last two accounting years. It also takes into consideration company ownership structure and constrains variation in the SME status over time by requiring that in order to change its SME status, a company must fall in the new category two consecutive accounting periods (two-year rule). If a firm is below the threshold in year $t$, it must be above the threshold in both years $t+1$ and $t+2$ to lose its SME status in year $t+2$. Otherwise, it remains an SME in both subsequent years as it has been in year $t .{ }^{14}$

We focus on the major change to the scheme that commenced from August 2008. The SME assets threshold was increased from $€ 43 \mathrm{~m}$ to $€ 86 \mathrm{~m}$, the employment threshold from 249 to 499 and the sales threshold from $€ 50 \mathrm{~m}$ to $€ 100 \mathrm{~m} .{ }^{15}$ As a result of these changes, a substantial proportion of companies that were eligible for the large company rate according to the old definition became eligible for the SME rate. In addition to the change in SME definition, the UK government also increased the enhancement rate for both SMEs and large companies in the same year. The SME enhancement rate increased from $50 \%$ to $75 \% .{ }^{16}$ For large companies, the rate changed from $25 \%$ to $30 \%$. The policy change implies a reduction in the tax-adjusted user cost of R\&D from 0.19 to 0.15 for the newly-eligible SMEs whereas the user cost for large companies was basically unchanged (see sub-section 5.2 below and Table A11).

We examine the impact of this jump from 2008 onwards in tax-adjusted user cost of R\&D at the new SME thresholds. There are several advantages of employing this reform instead of the earlier changes. First, unlike the previous thresholds based on the EU definition, which were extensively used in many other support programs targeting SMEs, the thresholds introduced in 2008 were specific to the R\&D Tax Relief Scheme. This allows us to recover the effects of the R\&D

\footnotetext{
${ }^{13}$ We use the terms "sales", "turnover" and "revenue" interchangeably in the paper, except when more precise definitions are needed.

${ }_{15}^{14}$ For further details of the EC criteria see Recommendations 1996/280/EC and 2003/361/EC (see Appendix A1).

${ }^{15}$ The other criteria laid down in the EC 2003 recommendation (e.g. two-year rule) were maintained in the new provision in Finance Act 2007 (Chapter 11). This act did not appoint a date on which new ceilings became effective. The date was appointed in the Finance Act 2007, Section 50 (Appointed Day) Order 2008 of July $16^{\text {th }} 2008$.

${ }^{16}$ In parallel, the SME payable tax credit rate was cut slightly to $14 \%$ (from 16\%) of enhanced R\&D expenditure (i.e. $24.5 \%$ of R\&D expenditure) to ensure that R\&D tax credit falls below the $25 \%$ limit for state aid.
} 
Tax Relief Scheme without confounding them with the impact of other SME schemes. Second, identifying the impacts around newly introduced thresholds mitigates biases arising from tax planning of R\&D intensive firms which may cause endogenous bunching of firms around the thresholds. We show that firms did respond rationally by starting to bunch around the new thresholds in 2009 and afterwards. But we also demonstrate that there was no bunching around the threshold in 2007 (or earlier) and covariates were all balanced at the cutoff. The 2007 value of assets is therefore what we use as the running variable. This is important as although the policy was not completely detailed until July 2008 (and implemented in August 2008), aspects of the policy were understood in 2007 so firms may in principle have responded in advance. Information frictions, adjustment costs and policy uncertainty mean that this adjustment is likely to be sluggish, especially for the SMEs we study. ${ }^{17}$

We will focus on assets as our key running variable. This is one of the three determinants of SME status and, unlike employment and sales, does not suffer from missing values in the available datasets. We discuss this in detail in Section 4 and also consider using employment and sales in sub-section 6.4. We use the 2007 value of assets as this will matter for SME tax status in 2009 which depends on the past two accounting years as discussed above. Since the policy only began mid-way through 2008, it is inappropriate to use values in 2008 as running variables. Nevertheless, we also examine the results' robustness when we consider other years for the running variable.

\section{Empirical strategy}

We start with a simple R\&D equation of the form:

$$
r d_{i, t}=\alpha_{1, t}+\beta_{F S, t} E_{i, 2007}+f_{1, t}\left(z_{i, 2007}\right)+\varepsilon_{1 i, t}
$$

where $t=2009,2010,2011$ following the 2008 policy change and $\varepsilon_{1 i, t}$ is an error term. $r d_{i, t}$ is $\mathrm{R} \& \mathrm{D}$ the expenditure of firm $i$ in year $t$ and $E_{i, 2007}=I\left\{z_{i, 2007} \leq \tilde{z}\right\}$ is a binary indicator equal to one if assets in $2007\left(z_{i, 2007}\right)$ are equal to or less than the corresponding new SME threshold, $\tilde{z}$. The coefficient of interest $\beta_{F S}$ (subscript "FS" for First Stage) estimates the effect of the difference in tax relief schemes between SMEs and large firms on R\&D spending. In an RD Design framework, the identification assumption requires that the distribution of all predetermined variables is smooth around the threshold, which is testable on observables. The identification is guaranteed when firms cannot manipulate their running variable, $z_{i, 2007}$ (Lee, 2008). Under this assumption,

\footnotetext{
${ }^{17}$ Sluggish adjustment to policy announcements is consistent with many papers in the public finance literature (e.g. Kleven and Waseem, 2013).
} 
eligibility, $E_{i, 2007}$, is as good as randomly assigned at the cutoff. We consider year by year regressions of equation (1) as well as averaging over three post-policy years. We also estimate identical regressions in the pre-policy years to assess the validity of the RD Design.

Equation (1) can be derived from the static first order condition of a firm with an R\&D augmented CES production function (see Appendix A). We show how the elasticity of R\&D with respect to its user cost can be derived in Section 5 below.

As is standard in RD Designs, we control for separate polynomials of the running variable on both sides of the asset threshold of $€ 86 \mathrm{~m} .{ }^{18}$ As noted above, because of the two-year rule, a firm's SME status in 2009 is partly based on its financials in 2007. These are unlikely to be manipulated by firms for tax planning purpose since the start date of the new SME definition (August $1^{\text {st }}$ 2008) was only announced on July $16^{\text {th }} 2008 .{ }^{19}$ Using total assets in 2007 as our primary running variable thus mitigates the concern that there may have been endogenous sorting of firms across the threshold. Nevertheless, since there were discussions of the change in thresholds in late 2006 we are careful to check for continuity of observables around the thresholds even in 2007.

Notice that the "new SMEs", i.e. those who became SMEs only under the new definition, could only obtain the higher tax deduction rates on R\&D performed after August 2008. Hence, to the extent that firms could predict the change in thresholds in early 2008 (or they could manipulate the reported timing of within year R\&D), such companies would have an incentive to reduce 2008 R\&D expenditures before August and increase them afterwards. To avoid these complexities with the transition year of 2008, we focus on 2009 and afterwards as full post-policy years.

Figure 1 shows that the distribution of firms' 2007 assets appears continuous around the new 2008 SME threshold of $€ 86 \mathrm{~m}$. The McCrary test gives a discontinuity estimate (log difference in density height at the SME threshold) of -0.026 with a standard error of 0.088 , insignificantly different from zero. Sub-section 6.3 discusses how there is also no discontinuity in earlier years, but how this changes in later years in response to the policy change.

In terms of innovative outputs we consider the following patent equation analogous to the R\&D equation (1):

$$
\text { pat }_{i, t}=\alpha_{2, t}+\beta_{R F, t} E_{i, 2007}+f_{2, t}\left(z_{i, 2007}\right)+\varepsilon_{2 i, t}
$$

\footnotetext{
${ }^{18}$ In the baseline results we use a first order polynomial being mindful of Gelman and Imbens's (2014) warning against using higher order polynomials when higher order coefficients are not significant. We show in robustness checks that including higher order polynomials produce qualitatively similar results across all specifications.

${ }^{19}$ Finance Act 2007, Section 50 (Appointed Day) Order 2008 of July $16^{\text {th }} 2008$.
} 
where the dependent variable is the number of patents, $p a t_{i, t}$. Under the same identification assumptions discussed above, $\beta_{R F}$ ("RF" for Reduced Form) estimates the causal effect of the policy on patents.

Finally we consider the "structural" patents equation:

$$
\text { pat }_{i, t}=\alpha_{3, t}+\gamma_{3, t} r d_{i, t}+f_{3, t}\left(z_{i, 2007}\right)+\varepsilon_{3 i, t}
$$

which can interpreted as a "knowledge production function" as in Griliches (1979). Equations (1) and (3) correspond to a fuzzy RD model identifying the impact of additional R\&D spending induced by the difference in tax relief schemes on firms' innovation output, using $E_{i, 2007}$ as the instrument for R\&D. With homogenous treatment effects, IV delivers the causal effect of R\&D on patents under the exclusion restriction that the threshold indicator $E_{i, 2007}$ does not affect innovation outputs through any other channel. ${ }^{20}$

\section{Data}

\subsection{Data sources}

Appendix B details our data sources. Our data comes from three main sources: (1) the HMRC (Britain's IRS) Corporate Tax returns (CT600) and its extension, the Research and Development Tax Credits (RDTC) dataset, which provide data on the universe of UK firms and importantly includes firm's R\&D expenditures as claimed under the R\&D Tax Relief Scheme, (2) Bureau Van Dijk's FAME dataset which provides data on the accounts of the universe of UK incorporated firms, and (3) PATSTAT which has patent information on all patents filed by UK companies in the main 60 patent offices across the world.

CT600 is a confidential administrative panel dataset provided by HMRC Datalab which consists of tax assessments made from the returns for all UK companies liable for corporation tax. It is made accessible to researchers only since 2011. The dataset covers financial years 2000-01 to 2011-12 21 , with close to 16 million firm by year observations, and contains all information provided by firms in their annual corporate tax returns. We are specifically interested in the RDTC dataset, which consists of all information related to the R\&D Tax Relief Scheme including the amount of qualifying R\&D expenditure each firm has in a year and the scheme under which it

\footnotetext{
${ }^{20}$ With heterogeneous treatment effects, IV requires a monotonicity assumption that moving a firm's size slightly below the threshold always increases R\&D. In this case, $\gamma_{3}$ is the Average Causal Response (Angrist and Imbens 1995), a generalization of the Local Average Treatment Effect that averages (with weights) over firms' causal responses of innovation outputs to small changes in R\&D spending due to the IV.

${ }^{21}$ The UK fiscal year runs from April $1^{\text {st }}$ to March $31^{\text {st }}$ so 2001-02 refers to data between April $1^{\text {st }} 2001$ and March $31^{\text {st }} 2002$. In the text we refer to the financial years by their first year, so 2011-2012 is denoted "2011".
} 
makes the claim (SME vs. Large Company Scheme).

Firms made a total of 53,000 claims between 2006 and 2011 (22,000 claims between 2006 and 2008 and 31,000 claims between 2009 and 2011), about 80\% of which are under the SME Scheme. Total claims amounted to $£ 2.5$ bn in R\&D tax relief in total between 2006 and 2008 and $£ 3.3$ bn between 2009 and 2011.22

We only observe total R\&D when firms seek to claim R\&D tax relief. All firms performing R\&D are in principle eligible for tax breaks which as we have discussed are generous. Further, all firms must submit tax returns each year and claiming tax relief is a simple part of this process. Hence we believe we have reasonably comprehensive coverage of current R\&D spending. Ideally, we would cross check at the firm level with R\&D data from other sources, but UK accounting regulations (like the US regulation of privately listed firms) do not insist on SMEs reporting their R\&D, so there are many missing values. Statistics provided by internal HMRC analysis indicate that qualifying R\&D expenditure amounts to $70 \%$ of total business R\&D (BERD). ${ }^{23}$ Note that the other outcomes (like patents) are observed for all firms, regardless of R\&D status.

CT600 makes it possible to determine the SME status of firms who claim the R\&D tax relief, but not the SME status of firms who are not claiming (the vast majority of firms). Employment and total assets are not available because such information is not directly required on corporate tax forms. Furthermore, only tax-accounting sales is reported in CT600, while the SME definition is based on financial-accounting sales as reported in company accounts. ${ }^{24}$ Consequently, we turn to a second dataset, FAME, which contains all UK company accounts since about the mid-1980s. We match CT600 to FAME by an HMRC-anonymized version of company registration number $(\mathrm{CRN})$, which is a unique regulatory identifier in both datasets. We merged 95\% of CT600 firms between 2006 and 2011 with FAME and these firms cover close to $100 \%$ of R\&D performing firms and patenting firms. Unmatched firms are slightly smaller but not statistically different from matched ones across different variables reported in CT600, including sales, gross trading profits, and gross and net corporate tax chargeable (see Appendix B4).

\footnotetext{
${ }^{22}$ It is currently not possible to merge CT600 with the BERD firm survey which is used to build the national estimate of R\&D. The BERD survey (like US BERDIS) is a stratified random sample with very partial coverage of SMEs, however, so there would only be partial coverage.

${ }^{23}$ There are various reasons for this difference, including the fact that BERD includes R\&D spending on capital investment whereas qualified $R \& D$ does not (only current expenses are liable). It is also the case that HMRC defines $\mathrm{R} \& \mathrm{D}$ more narrowly for tax purposes that BERD which is based on the Frascati definition.

${ }^{24}$ Tax-accounting sales turnover is calculated using the cash-based method, which focuses on actual cash receipts rather than their related sale transactions. Financial-accounting turnover is calculated using the accrual method, which records sale revenues when they are earned, regardless of whether cash from sales has been collected.
} 
All firms are required to report their total assets in company accounts, but reporting of sales and employment is mandatory only for larger firms. In our 2006 to 2011 FAME data, only 5\% of firms reported employment and only 15\% reported sales. By comparison $97 \%$ reported assets. Even in our baseline sample of relatively larger firms around the SME asset threshold of $€ 86 \mathrm{~m}$, employment and sales coverage is still only reported by $55 \%$ and $67 \%$ of firms respectively. For this reason, we only focus on exploiting the SME asset threshold with respect to total assets and use this as the key running variable in our baseline specification. Financial variables are reported in sterling while the SME thresholds are set in euros, so we convert assets and sales using exactly the same tax rules used by HMRC for this purpose. In addition, FAME provides industry, location, capital investment, profits, remuneration, etc., though coverage differs across variables.

We use assets from FAME as our key running variable, but also experiment with using sales to determine SME status, despite the greater number of missing values. In principle, using both running variables should increase efficiency, but in practice (as we explain in sub-section 6.4) it does not lead to material gains in the precision of the estimates. The fact that we use only one of the three SME criteria for determining eligibility does not violate the assumptions for RD Design, it may just reduce the efficiency of our estimates.

The third dataset we exploit is PATSTAT, a database curated by the European Patent Office (EPO). PATSTAT is the largest available international patent database and covers close to the population of all worldwide patents since the 1900s. It brings together nearly 70 million patent documents from over 60 patent offices, including all of the major offices such as the European Patent Office, the United States Patent and Trademark office (USPTO) and the Japan Patent Office (JPO). Patents filed with the UK Intellectual Property Office (UK IPO) are also included. To assign patents to UK-based companies we use the matching between PATSTAT and FAME implemented by Bureau Van Dijk and available from the ORBIS database. The quality of the matching is excellent: over our sample period, $94 \%$ of patents filed in the UK and $96 \%$ of patents filed at the EPO have been successfully associated with their owning company. We select all patents filed by UK companies between 1980 and 2013. ${ }^{25}$ Our dataset contains comprehensive information from the patent record, including application date, citations, and technology class. Importantly, PATSTAT includes information on patent families, which are sets of patents protecting the same invention across several jurisdictions. This allows us to identify all patent applications filed worldwide by UK-based

\footnotetext{
${ }^{25}$ To avoid double counting, a patent filed by more than one firm is distributed equally among the firms. For example, a patent filed by 2 firms is counted as 0.5 for each of the firms.
} 
companies and to avoid double-counting inventions that are protected in several countries. ${ }^{26}$

In our baseline results, we use the number of patent families - irrespective of where the patents are filed - as a measure of the number of inventions for which patent protection has been sought. This means that we count the number of patents filed anywhere in the world by firms in our sample, whether at the UK, European or US patent office, but we use information on patent families to make sure that an invention patented in multiple jurisdictions is only counted once. Patents are sorted by application year. Our measures use all patent application to avoid artificially truncating the sample, as the granting of a patent is a long administrative process (3.3 years on average in the UK, see Dechezleprêtre, 2013).

Numerous studies have demonstrated a strong link between patenting and firm performance. ${ }^{27}$ Nevertheless, patents have their limitations (e.g. Hall et al., 2013). To tackle the problem that the value of individual patents is highly heterogeneous, we (i) show results separately for high value EPO patents vs. UK patents, (ii) use data on the number of countries that IP protection is sought, (iii) look only at granted patents instead of all applications and (iv) weight patents by future citations. $^{28}$

\subsection{Baseline sample descriptive statistics}

We construct our baseline sample from the above three datasets. Our baseline sample contains 5,888 firms with total assets in 2007 between $€ 61 \mathrm{~m}$ and $€ 111 \mathrm{~m}$ which survive ${ }^{29}$ at least until 2008 based on a $€ 25 \mathrm{~m}$ bandwidth around the threshold, with 3,651 firms under the $€ 86 \mathrm{~m}$ SME asset threshold and 2,327 firms above the threshold. The bandwidth of $€ 25 \mathrm{~m}$ is somewhat arbitrary, so we show robustness to a range of alternative bandwidths. ${ }^{30}$ Our key outcome variables include amount of qualifying R\&D expenditure, and number of patents filed. All nominal variables are converted to 2007 prices using the UK Consumer Price Index, and all outcome variables are winsorized at $2.5 \%$ of non-zero values to mitigate the leverage of outliers. ${ }^{31}$ In 2006-08 224 of the

\footnotetext{
${ }^{26}$ This means that thanks to patent family information our dataset includes patents filed by foreign affiliates of UK companies overseas that relate to an invention filed by the UK-based mother company. However, patents filed independently by foreign affiliates of UK companies overseas are not included.

${ }^{27}$ For example, see Hall, Jaffe and Trajtenberg (2005) on US firms or Blundell, Griffith and Van Reenen (1999) on UK firms.

${ }^{28}$ Variations of these quality measures have been used by inter alia Lanjouw et al. (1998), Harhoff et al. (2003) and Hall et al. (2005).

${ }^{29}$ Firms who die are kept in the sample to avoid selection bias, but are given zero R\&D.

${ }^{30}$ The Imbens and Kalyanaraman (2011) optimal bandwidth for using R\&D as the outcome variable is 22 , which is close to our baseline choice of 25 .

${ }^{31}$ This is equivalent to "winsorizing" the R\&D of the top 5 to $6 \mathrm{R} \& \mathrm{D}$ spenders and the number of patents of the top 2 to 4 patenters in the baseline sample each year. We also show robustness to excluding outliers instead of winsorizing outcome variables.
} 
firms in this sub-sample had positive $R \& D$ and this number rose to 254 over 2009-11 (roughly 5\% of aggregate R\&D expenditure). 210 firms filed 327 patents over 2006-08, and 157 firms filed 285 patents over 2009-11.

In the 2006-2008 period firms below the threshold spent on average $£ 57,800$ per annum on $R \& D$ and firms above the threshold spent an average of $£ 94,500$ (with an overall average of $£ 72,300$ ). After the policy between 2009 and 2011 these numbers changed to $£ 72,000$ and $£ 93,600$. In other words, the gap in R\&D spending between the two groups of firms around the threshold almost halved from $£ 36,700$ pre-policy to $£ 21,600$ post-policy. In terms of innovation outputs, the average number of patents per annum was similar between the two groups of firms before the policy change (0.06), while after the policy change, firms below the SME asset threshold filed $30 \%$ more patents than those above the threshold ( 0.06 vs. 0.04 ). Detailed descriptive statistics by year across the two groups are in Table 1.

These "difference in differences" estimates are consistent with our hypothesis that the 2008 policy change induces firms below the new SME asset threshold, which are more likely to benefit from more generous tax relief under the SME scheme, to increase their R\&D and patents. Guceri (2015) and Guceri and Li (2015) come to the same conclusion using a difference in difference approach. ${ }^{32}$ However, there could be differential time trends correlated with size which could confound these simple comparisons between smaller and larger firms. We now turn to implementing the RD Design of equations (1)-(3) to investigate the causal effects directly.

\section{Results}

\subsection{Main results}

Table 2 reports $R \& D$ regressions (equation (1)). The key explanatory variable is whether the firm's total assets in 2007 was below the new SME asset threshold of $€ 86 \mathrm{~m}$. The sample is limited to firms with total assets in 2007 between $€ 61 \mathrm{~m}$ and $€ 111 \mathrm{~m}$, and the running variable is the firms' total assets in 2007. Looking at each of the three "pre-policy" years 2006 to 2008 in columns (1) to (3), we find that as expected there is no significant discontinuity in R\&D at the asset threshold

\footnotetext{
${ }^{32}$ Unlike our paper they look only at R\&D, however, and not patents or other firm performance outcomes. Furthermore, they condition on R\&D performing firms which (i) creates selection issues and (ii) means that they cannot look at the extensive margin (i.e. they cannot examine whether any firms start or stop performing R\&D as a result of the tax changes).
} 
before the new SME definition became effective toward the end of $2008 .^{33}$ In the next three columns we observe that from 2009 onward, firms just below the SME threshold have significantly more R\&D than firms just above the threshold. Column (7) averages the three pre-policy years and column (8) the three post policy years. The discontinuity implies a causal annual effect of $£ 138,500$ per firm, compared to an insignificant effect pre-policy. Column (9) presents the difference between columns (8) and (7) and even in this specification there is a causal effect of $£ 75,300$. Although formally, our analysis indicates no pre-policy trends, we consider this a conservative approach. ${ }^{34}$ An effect of $£ 75,300$ per annum about doubles the average R\&D per annum observed in the pre-policy period $(£ 72,300)$, suggesting that the policy had a substantial impact from an economic as well as statistical perspective.

Figure 2 shows visually the discontinuous jumps in R\&D at the SME asset threshold of $€ 86 \mathrm{~m}$. While total assets correlate positively with both outcome variables in the regions just above and just below the threshold, as shown by the upward sloping regression lines, right across the threshold, there is a sudden jump in R\&D expenditure. The size of the jump corresponds to the estimate in column (8) of Table 2 and is statistically significant at the 5\% level.

Table 3 directly checks our RD identification assumption by looking at covariate balance. Firms right below and above the threshold are similar to one another in their observable characteristics prior to the policy change. The differences in sales, employment, and capital between the two groups of firms in 2006 and 2007 are both small and statistically insignificant in columns (1) through (6). After the policy change, we should not observe any discontinuity in R\&D around any asset threshold other than the true SME asset threshold of $€ 86 \mathrm{~m}$. To test this we ran a series of placebo tests on "pseudo" thresholds and found no significant effects. In column (7) we use a lower threshold of $€ 71 \mathrm{~m}$ with as an upper bound the true threshold of $€ 86 \mathrm{~m}$ and as a lower bound $€ 46 \mathrm{~m}$ (€25m below the lower pseudo-threshold as in the baseline). In column (8) we use a higher threshold of $€ 101 \mathrm{~m}$ with as a lower bound the true threshold of $€ 86 \mathrm{~m}$ and as an upper bound $€ 116 \mathrm{~m}$ (€25m above the higher pseudo-threshold). Neither experiment yield statistically significant effects. We also run similar placebo tests using all possible integer "pseudo" thresholds between

\footnotetext{
${ }^{33}$ The coefficient of 32 in 2008 is a third smaller than in 2007 (although both are insignificant). As noted above, this could be because firms were delaying their R\&D in the start of 2008 (before the R\&D threshold was changed in August) to the latter part of 2008 or even 2009. The fact that the policy effect in 2010 and 2011 are larger than 2009 makes this somewhat unlikely, but does highlight the difficulty of interpreting the 2008 data (which is another reason for using 2007 as the running variable).

${ }^{34}$ Alternatively we can condition directly on lagged R\&D in the regressions. In Table A3, column (4) shows that we obtain treatment effects (standard error) of $£ 82,000(36,400)$ when we do this over the 2009-11 period, very similar to the $£ 75,300$ figure in column (9).
} 
$€ 71 \mathrm{~m}$ and $€ 101 \mathrm{~m}$ with a band ranging from $€ 25 \mathrm{~m}$ below to $€ 25 \mathrm{~m}$ above the pseudo threshold (we do not truncate the band at the true threshold for these specifications). Figure A1, which plots the resulting coefficients and their $95 \%$ confidence interval against the corresponding thresholds, shows that the estimated discontinuities in R\&D peaks at the true threshold of $€ 86 \mathrm{~m}$, while they are almost not statistically different from zero anywhere else.

Our results are robust to a wide range of robustness tests (see Table A3). First, if we add a second order polynomial to the baseline specification of column (8) in Table 2, the treatment effect (standard error) is larger at 171.2 (87.4) and the coefficient (standard error) on the first and second order assets terms are $0.1(0.6)$ and $0.3(0.7) .{ }^{35}$ Second, the results are also robust to adding lagged dependent variable controls, industry and/or location fixed effects. ${ }^{36}$ Third, we obtain statistically significant effects of comparable magnitude when using a Poisson specification instead of OLS. ${ }^{37}$ Fourth, the discontinuity remains significant when we narrow the sample bandwidth or when we give more weights to firms closer to the asset threshold. ${ }^{38}$ Fifth, our estimates are robust to the choice of winsorization. Finally, all of our outcomes are conditional on survival. We also evaluate the same specification as in Table 3 but using survival as the dependent variable. The resulting treatment effect is small and insignificant.

Table 4 reports the patent regressions (equation (2)) using the same specification and sample as Table 2. As with R\&D, the first three columns show no significant discontinuity around the threshold for patenting activity prior to the policy 2006-08. By contrast, there is a significant increase in patenting in the post-policy period from 2009 onward (columns (3) to (6)). According to column (8) there is a significant average increase of 0.073 patents per year per firm as a result of the policy. The coefficient for the pre-policy period is half the size and statistically insignificant (column (7)). If we use the before and after differences, this is still significant at $10 \%$ level with a treatment effect of 0.035 , a substantial increase over the pre-policy sample mean of 0.060 (i.e. $58 \%$ more patents). This is a key result, as the R\&D policy was not based on patents, so there is no

\footnotetext{
${ }^{35}$ If we add a third order polynomial the treatment effect rises further to 175.3 , but is no longer statistically significant. The F-test on joint significance of the four higher order terms, however, is 1.05 (corresponding p-value of 0.38 ), suggesting their addition does not improve the fit much but comes at the cost of reduced precision of the estimation due to higher degrees of freedom.

${ }^{36}$ Adding R\&D in 2007 or average R\&D over 2006-08 as a control variable gives coefficients (standard error) of 75.5 (37.6) and 82.0 (36.4), similar to result from the baseline after-before design. Adding industry (4-digit SIC) fixed effects or location (2-digit postcode) fixed effects gives coefficients (standard errors) of 125.6 (61.2) and 107.4 (49.5).

${ }^{37}$ We do this to allow for a proportionate effect on R\&D (as in a semi-log specification). Using Poisson specification gives treatment effects (standard errors) of 1.62 (0.57) without lagged dependent variable control and $1.08(0.54)$ when controlling for R\&D in 2007. This is similar to the proportionate effects in Table 2.

${ }^{38}$ Using bandwidths of $€ 35 \mathrm{~m}$ or $€ 15 \mathrm{~m}$ gives coefficients (standard errors) of 43.6 (43.5) and 182.0 (73.5). Using Epanechnikov-kernel or triangular-kernel weights gives coefficients (standard errors) of 148.6 (57.8) and 151.9 (60.8).
} 
incentive to relabel other activities as "research". It may be surprising that the patent response is so speedy, but patent applications are usually timed quite closely to research expenditures in most sectors. We ran all the robustness tests discussed for the R\&D equation also on the patent regressions (see Table A4).

Figure 3 illustrates the discontinuity in the total number of patents filed over 2009-11 at the SME asset threshold of $€ 86 \mathrm{~m}$, which corresponds to the estimate column (8) of Table 4. As with R\&D there is clear evidence of the discontinuity in innovation outcomes at directly the point of the tax threshold. Furthermore, "pseudo" threshold tests similar to those discussed in Table 3 show that the estimated discontinuities in patent counts peak at the real SME threshold of $€ 86 \mathrm{~m}$ and are not statistically different from zero elsewhere (Figure A2).

As patents vary widely in quality, one important concern is that the additional patents induced by the policy could be of lower value. Table 5 investigates this possibility by considering different ways to control for quality. Column (1) reproduces our baseline results of patent counts. Column (2) counts only patents that are filed at the European Patent Office (EPO). It is around six times more costly to file a patent at the EPO than just at the UK patent office. ${ }^{39}$ Consequently, EPO patents are likely to be of higher value - only about a third of firms who filed UK patents in our sample also filed at the EPO. It is clear that there is a significant and positive effect on these high value patents and on the lower value patents filed in the UK (but not necessarily elsewhere) as shown in column (3). Although the point estimate is larger for UK patents than EPO patents (0.094 vs. 0.37), so is the mean (see base of the column), so the proportionate increase in patents is by a factor of about 1.2 in both columns (0.037/0.031 and 0.094/0.077).

As an alternative measure of patent value, we use data on family size, i.e. we count the number of jurisdictions in which each invention is patented. Since firms have to bear administrative costs for taking out intellectual protection in each country, the larger the family size, the more valuable the patent is likely to be. Compared to citations (see below), an advantage of patent family as a quality indicator is that all patent applications of the same invention need to be filed within (at most) 30 months after the first filing date. Hence, information on family size is available more quickly than patent citations. Column (4) of Table 5 uses this measure as a dependent variable and again finds a significant causal effect, showing almost a doubling of patenting activity. ${ }^{40}$ Column

\footnotetext{
${ }^{39}$ Filing a patent at the European Patent Office costs around $€ 30,000$ (Roland Berger, 2005). In contrast, filing a patent at the UK IPO costs $£ 3,000$ to $£ 5,000$ (i.e. $€ 4,000$ to $€ 6,000$ ).

${ }^{40}$ We also look at average family size per patent as a measure of patent value (we assign average family size value of
} 
(5) looks at the number of patents subsequently granted (rather than all applications), which also results in a positive and significant estimate.

Concerns have been raised that many patents are of dubious value and standards have slackened (e.g. business processing methods like Amazon's “one click" patent). It is generally agreed though, that patents in chemicals (such as biotechnology or pharmaceutical patents) remain of high value. Consequently, column (6) of Table 5 looks at chemical patents as an outcome and column (7) at non-chemical patents. Both dependent variables show a positive and significant effect of the policy with proportionate effects which are, if anything, larger in the "high quality" chemical patent sector. ${ }^{41}$ Finally, if we weight EPO patents by future citations we obtain a coefficient (standard error) of 0.004 (0.002) as shown in column (8) of Table 5. In column (9), the UK measures are similar in proportionate terms, but insignificant at conventional levels. ${ }^{42}$ We need to keep in mind that our data is very recent. For example, patents applied for in 2011 will have been published in 2012 or 2013 and hence will have had very little time to be cited. ${ }^{43}$

In summary, there is no strong evidence from Table 5 of any fall in innovation quality as a result of the policy.

Table 6 reports IV patents regressions where the key right hand side variable, R\&D, is instrumented by the discontinuity in the tax threshold. ${ }^{44}$ Column (1) presents the OLS version which shows a positive association between patents and R\&D. Column (2) presents the IV results which increases the coefficient substantially (although the two estimates are not statistically different on the basis of a Hausman test presented at the base of the column). The IV estimate implies that one additional patent costs on average $£ 1.9 \mathrm{~m}(=1 / 0.53)$ in additional qualifying $R \& D$ expenditure. Columns (3) and (4) show OLS and IV results for EPO patents and the final two columns for UK patents. All have significant effects, although they are larger for IV than OLS. The corresponding costs for one additional UK patent or one additional EPO patent is $£ 1.5 \mathrm{~m}$ and $£ 3.7 \mathrm{~m}$ respectively

\footnotetext{
zero to firms with no patents). The resulting coefficient (standard error) of $0.0038(0.0314)$ is also positive, although not statistically significant.

${ }^{41}$ If we narrow the outcome still further to only bio-pharmaceutical patents the coefficient (standard error) is even larger in proportionate terms: $0.013(0.006)$ on a pre-policy mean of 0.005 .

42 The coefficients (standard errors) obtained when we weight UK patents or all patents by future citations are 0.023 (0.021) and $0.012(0.012)$. We also look at average citations per patent as a measure of patent value (again, we assign average citations value of zero to firms with no patents). This gives coefficients (standard errors) of 0.0010 (0.0010) for EPO patents and -0.0015 (0.0028) for UK patents. Both estimates are statistically insignificant.

${ }^{43}$ Patents are published 18 months after the application date.

${ }^{44}$ In the corresponding IV model, the estimate of the first-stage effect of the instrument on R\&D is the coefficient on the threshold dummy in column (8) of Table 2.
} 
(columns (4) and (6)), which reflects that fact that only inventions of higher value typically get patented at the EPO. These figures are broadly in line with the existing estimates for R\&D costs per patent of $\$ 1 \mathrm{~m}$ to $\$ 5 \mathrm{~m} .{ }^{45}$ We again subject these IV regression to the robustness tests discussed for the first stage and reduced form regressions to show that the magnitudes are robust (Table A5).

\subsection{Magnitudes and tax-price elasticities}

What is the implied elasticity of R\&D with respect to its tax-adjusted user cost? Following the existing literature, ${ }^{46}$ we define the elasticity as the percentage increase in R\&D capital with respect to the percentage increase in the tax-adjusted user cost of R\&D capital. In our setting, the tax-price elasticity of $R \& D \eta$ is given by:

$$
\eta=\frac{\ln \left(r d_{S M E} / r d_{L C O}\right)}{\ln \left(\rho_{S M E} / \rho_{L C O}\right)}
$$

where $r d_{S M E}$ and $r d_{L C O}$ are the R\&D of a firm under the SME scheme and under the large companies ("LCO") scheme respectively, ${ }^{47}$ and $\rho_{S M E}$ and $\rho_{L C O}$ are the tax-adjusted user cost of R\&D facing the firm faces under the corresponding schemes.

Table 2 column (9) generated a treatment effect of $£ 75,300$, about a doubling over the prepolicy average $R \& D$ of $£ 72,300 .{ }^{48}$ Using these figures for our baseline tax-price elasticity calculation gives us a $\log$ difference in $\mathrm{R} \& \mathrm{D}$ of $\ln \left(r d_{S M E}\right)-\ln \left(r d_{L C O}\right)=\ln (75.3+72.3)-$ $\ln (72.3)=0.71 .{ }^{49}$ We calculate the tax-adjusted user cost, $\rho_{f}$, based on the actual design of the R\&D Tax Relief Scheme (see Table A1 and Appendix A4 for more details):

$$
\rho_{f}=\frac{\left(1-A_{f}\right)}{\left(1-\tau_{f}\right)}(r+\delta)
$$

where sub-script $f \in\{S M E, L C O\}$ denotes whether the firm is a smaller (SME) or larger company ( $L C O), A$ is the value of $\mathrm{R} \& \mathrm{D}$ tax relief, $\tau$ is the effective corporate tax rate, $r$ is the real interest

\footnotetext{
${ }^{45}$ Hall and Ziedonis (2001); Arora, Ceccagnoli, and Cohen (2008); Gurmu and Pérez-Sebastián (2008); Dernis et al. (2015).

${ }^{46}$ For example, Hall and Jorgenson (1967) or Bloom, Griffith, and Van Reenen (2002).

${ }^{47}$ Formally, the numerator of the tax price elasticity should be the R\&D capital stock rather than flow expenditure. However, in steady state the R\&D flow will be equal to R\&D stock multiplied by the depreciation rate. Since the depreciation rate is the same for large and small firms around the discontinuity, it cancels out (see Appendix A).

${ }^{48}$ As the tax-adjusted user cost of R\&D for large companies remains unchanged over 2006-11 (Table A11), it seems reasonable to use the average $R \& D$ over 2006-08 as a proxy for how much an average firm would spend on R\&D if it remained a large company over 2009-11.

${ }^{49}$ For robustness checks, we use estimates from various alternative first stage specifications, including both OLS and Poisson specifications, and derive estimates for log difference in $R \& D$ investment in the range of 0.69 to 1.08 (see Appendix B).
} 
rate and $\delta$ is the depreciation rate. As described in Section 2, the R\&D Tax Relief Scheme includes a tax deduction feature for firms with corporate tax liabilities with different enhancement rates under the SME and large company schemes and a payable tax credit feature for firms with no corporate tax liability only under the SME scheme. ${ }^{50}$ In the case of tax deduction, the value of the tax relief $A_{d, f}$ is $A_{d, f}=\tau_{f}\left(1+e_{f}\right)$ where $e_{f}$ is the enhancement rate (which is $75 \%$ for SMEs and $30 \%$ for large companies in 2009-10 and 100\% for SMEs and 30\% for large companies in 2011). In the case of payable tax credit, the value of the tax relief $A_{c}$ is $A_{c}=c(1+e)$ where $c$ is the payable tax credit rate (which is 14\% for SMEs in 2009-11 and 12.5\% for SMEs in 2011 and always zero for large companies). Finally, the average tax-adjusted user cost of R\&D under each scheme is an average of the user costs under each case, weighted by the probability, $\operatorname{Pr}($.$) , that a firm will have$ no corporate tax liability:

$$
\rho_{f}=\operatorname{Pr}(\text { Has tax liability }) \times \rho_{\text {scheme }}^{\text {deduction }}+\operatorname{Pr}(\text { No tax liability }) \times \rho_{\text {scheme }}^{\text {credit }}
$$

To calculate this we use the share of firms in the sample with corporate tax liabilities in 2006 and 2007, which is $45 \%$, as a proxy for $\operatorname{Pr}$ (Has tax liability). The effective tax rate $\tau$ was $28 \%$ in 2009-10 and $26 \%$ in $2011 .^{51}$ The average tax-adjusted user cost of R\&D is 0.15 under the SME scheme and 0.19 under the large company scheme over 2009-11, which translates into a log difference in user cost of 0.27 .

Putting all these elements together we obtain a tax-price elasticity of R\&D of 2.6 (= 0.71/0.27). This is somewhat higher than the typical values of between 1 and 2 found in other studies. $^{52}$ However, almost all previous studies have effectively focused on larger firms such as publicly listed firms or using state/macro data that are dominated by larger firms' expenditures. Our sample, by contrast, is predominantly of SMEs around the $€ 86 \mathrm{~m}$ threshold. As these firms are more likely to be credit constrained, they are likely to be more responsive to R\&D tax incentives.

Some evidence for the hypothesis that there are larger treatment effects for the more financially constrained firms is presented in Table 7. First, we split the sample by firm age, as younger firms are much more likely to be credit constrained than older ones. Splitting by median age we find that although the effect of the policy is significant in both sub-samples, it is proportionately larger for the young firms. R\&D rises by a factor of 2.4 for the young and only 1.9 for the old

\footnotetext{
${ }^{50}$ In some situations, a firm can first use the tax deduction feature to reduce its chargeable profits to zero, then claim the rest of the enhanced qualifying $R \& D$ expenditure using the payable tax credit feature. This is called a combination claim. However, as there are very few combination claims in our baseline sample, we ignore this case for simplicity.

${ }^{51}$ We set the real interest rate $r$ to $5 \%$ and depreciation rate $\delta$ to $15 \%$. As $\ln (r+\delta)$ cancels out in $\ln \left(\rho_{S M E} / \rho_{L C O}\right)$, the value of these two last parameters does not affect our estimate of the final tax-price elasticity.

${ }^{52}$ See the surveys in Becker (2015), OECD (2014), Fowkes, Sousa, and Duncan (2015), Hall and Van Reenen (2000).
} 
(columns (1) and (2)). Furthermore, when we use the after-before design, the treatment effect is significant for young firms, but smaller and insignificant for older firms (columns (3) and (4)). Estimates from the after-before design gives a treatment effect to baseline ratio of 2.6 for young firms and 0.5 for old firms, a difference that is significant at the $10 \%$ level (the implied tax price elasticities are 4.7 and 1.6 respectively). ${ }^{53}$

One issue is that young firms respond more to the R\&D tax policy not because they are financially constrained, but because they are more likely to have zero corporate tax liabilities and therefore benefit more from the SME scheme via payable tax credit. We directly address this concern by comparing the responses of young and old firms only among firms with corporate tax liabilities for at least one year between 2005 and 2007 (columns (5) to (8) of Table 6). As before, we find that young firms still have a much higher treatment effect to baseline ratio in this subsample: 2.4 to 0.5 among old firms, implying tax price elasticities of 4.8 and 1.6 respectively. Though these differences are not statistically significant due to smaller sample size, they support our hypothesis that the larger treatment effects we find are driven by financially constrained firms. ${ }^{54}$

\subsection{Cost effectiveness of the R\&D Tax Relief Scheme}

A full welfare analysis of the R\&D policy is complex as one needs to take into account general equilibrium effects through spillovers (see below) and possibly aggregate effects on scientists' wages (Goolsbee, 1998). We take one step in this direction by implementing a simple "value for money" calculation based on how much additional R\&D is generated per pound sterling of taxpayer money ("Exchequer Costs"). The details of the calculations are in Appendix A5, but we summarize them here.

As described in the previous sub-section, we obtain empirical estimates of the tax-price elasticity from the 2008 policy change. In addition, for every year we can also calculate the difference in the user costs of R\&D generated by the policy parameters of the tax system. We do this separately for each of the three R\&D schemes: SME deductible, SME payable tax credit and large company scheme. This allows us to calculate the value for money ratio, $\frac{\Delta_{R D}}{\Delta_{E C}}$ separately for each scheme in each year where $\Delta_{R D}$ is the change in aggregate business R\&D generated by the policy and $\Delta_{E C}$ is the Exchequer/tax payer cost of the program. From the HMRC data (HMRC 2015) we

\footnotetext{
${ }^{53}$ The log difference in the user cost of R\&D among younger firms is 0.274 (probability of payable tax credits is $67 \%$ ). The log difference in the user cost among older firms is 0.267 (probability of the payable tax credits is $44 \%$ ).

${ }^{54}$ Replicating the exercise using the sub-sample of firms with no corporate tax liabilities 2005-07 gives a treatment effect (relative to baseline R\&D) ratios of 2.8 for young firms and 0.5 for older firms, implying tax price elasticities of 4.7 and 1.5 respectively.
} 
also know the amount given out in each of the three schemes by the government $\left(\Delta_{E C}\right)$. Combining this with the value for money ratio (derived from the tax elasticity and the user costs) enables us to calculate the counterfactual level of aggregate $R \& D$.

The estimated R\&D tax-price elasticity of 2.6 implies that a firm entering the SME scheme as a result of the new threshold increases its $R \& D$ by $84 \%$ of its pre-policy level in the tax deduction case, and $109 \%$ of its pre-policy R\&D in the payable tax credit case. The corresponding increase in Exchequer costs by the same firm is $31 \%$ of its pre-policy R\&D in the tax deduction case, and $51 \%$ of its pre-policy R\&D in the payable tax credit case. In both cases, roughly half of this increase is to cover more generous tax relief applied to the firm's old level of R\&D, while the other half covers tax relief applied to the firm's additional R\&D. The implied "value for the money" ratio of the 2008 policy change, as measured by additional R\&D over additional Exchequer costs, thus ranges from 2.1 in the payable tax credit case to 2.7 in the tax deduction case.

If we generalize the estimated R\&D tax-price elasticity of 2.6 to the whole population of SMEs, we can do a similar calculation for the overall SME scheme between 2006 and 2011. Value for money ratios are on average 2.79 for the deduction scheme and 2.13 for the tax credit scheme. Combining these ratios with Exchequer costs statistics gives us estimates of the additional SME $R \& D$ induced which averages at $£ 719 \mathrm{~m}$ per year $(£ 321 \mathrm{~m}$ from the deductible and $£ 398 \mathrm{~m}$ from payable tax credit). Total SME qualified $R \& D$ averaged $£ 1,745 \mathrm{~m}$, so this is a substantial fraction. Our calculations suggest SME R\&D would have been $41 \%$ lower in the absence of the UK R\&D tax credit system.

We also repeat the exercise for the population of large companies, but with more conservative R\&D tax-price elasticity of $1.0^{55}$ as these firms are likely less responsive to tax incentives, and obtain value for the money ratios of around 1.4. These translate into an average of $£ 919 \mathrm{~m}$ additional R\&D (about $11 \%$ of total large firm's qualified R\&D spending).

Putting these figures together suggests that the R\&D Tax Relief Scheme induced an average of $£ 1.64 \mathrm{bn}$ per year 2006-11, while costing the Exchequer $£ 0.96 \mathrm{bn}$ in lost tax revenue - a value for money ratio of 1.7. The UK's qualifying R\&D spending would have been about $16 \%$ lower in the absence of this fiscal support. This suggests that the tax policy was important in the macroeconomic performance of UK R\&D. In Figure 4 we show estimates of the counterfactual business

\footnotetext{
${ }^{55}$ This follows the conclusions from literature surveys (e.g. Becker, 2014). These elasticity assumptions are likely to underestimate the benefits of the policy as (i) the literature may have under-estimated the elasticity due to weaker identification approached and (ii) since we find larger elasticities for medium sized firms, the responsiveness may be even larger for the much smaller firms who are well below the asset thresholds we consider.
} 
R\&D (BERD) to GDP ratio estimated in the absence of the tax relief scheme (see Appendix A.5 for details). It is striking that since the early 1980s UK BERD became an increasingly small share of GDP, whereas it generally rose in other major economies. According to our estimates this decline would have continued were it not for the introduction and extension of a more generous fiscal regime in the 2000s. ${ }^{56}$ Business R\&D would have been $10 \%$ lower over the $2006-2011$ period (total BERD is larger than tax qualifying R\&D).

A full welfare analysis would likely produce even larger benefit to cost ratios than 1.7. First, since the taxpayer costs are transfers, only the deadweight cost of tax should be considered (e.g. Gruber, 2011, uses 40\%). Second, the additional R\&D is likely to have technological spillovers to other firms, raising their innovation rates (e.g. Bloom et al. 2013). We examine these spillover effects in Section 7.

\section{Extensions and Robustness}

\subsection{Intensive versus extensive margins}

The additional amount of R\&D induced by the policy could come from firms which would not have done any R\&D without the scheme (i.e. the extensive margin) or from firms which would have done $R \& D$, although in smaller amounts (i.e. the intensive margin). It turns out that the main R\&D effects are coming from the intensive margin (Table A6). Estimating the R\&D equation where the outcome is a dummy for whether the firm performs R\&D produces insignificant effects. By contrast, when the outcome is whether a firm patents there remains a positive and significant effect. ${ }^{57}$ Similarly, if we split by industry, the strongest effects of the policy come from those sectors that are more intensive in $\mathrm{R} \& \mathrm{D}$ and patents (Table A8). ${ }^{58}$

We also split the baseline sample into firms which made some capital investment in the 200507 pre-policy period, and firms that did not (Table A9). ${ }^{59}$ The policy effect on R\&D and innovation is larger among firms who had invested, suggesting that current $R \& D$ and capital investments are

\footnotetext{
${ }^{56}$ The trend annual decline in business R\&D intensity was $1.9 \%$ between 1981 and 1999 . We estimate that in the absence of the policy change the decline would have continued at $1.7 \%$ a year 1999 to 2012 .

${ }^{57}$ Table A7 shows similar findings by splitting the sample by firms with and without R\&D or patents in the past. Both $R \& D$ and patent effects come mainly through the intensive margin, driven by firms with past $R \& D$ or patents.

${ }^{58}$ These are shown by splitting at median of industry patent intensity, and we generate the same qualitative pattern if we repeat the exercise using R\&D intensity. Examples of high-patenting industries include electric domestic appliances, basic pharmaceutical products, medical and surgical equipment, organic and inorganic basic chemicals, optical and photographic equipment, etc.

${ }^{59}$ Due to limited coverage of investments in FAME, we use data on machinery and plant expenditure reported in CT600 as a proxy for capital investments.
} 
more likely to be complements than substitutes. This result is consistent with the idea that firms having previously made R\&D capital investments have lower adjustment costs and therefore respond more to R\&D tax incentives (Agrawal, Rosell, and Simcoe 2014).

\subsection{R\&D tax effects on other aspects of firm performance}

We examine if the tax policy generated changes in other aspects of firm performance. We again use the baseline specification but use Total Factor Productivity (TFP) as the outcome variable. We proxy TFP by estimating a production function using the Olley and Pakes (1996) method. ${ }^{60}$ Table 8 Panel A shows that there appears to be some positive policy impact on TFP that is significant in the final column that represents the change in TFP. The effect magnitude of 0.241 is sizable, although the standard errors are also large. Since TFP is hard to measure we also examined more straightforward measures of firm size, including sales (Panel B), employment (Panel C), ${ }^{61}$ and capital (Panel D). The policy impacts on sales and employment exhibit the same pattern as that on TFP. In particular, the treatment effects grow over time for employment which is consistent with a dynamic where firms increase $R \& D$, then innovate and then grow larger. There is no effect on capital, which may reflect substitution towards intangible capital (R\&D) and away from tangible capital. We also looked at various alternative measures of TFP as robustness checks, including using Solow residual approach to calculate TFP, using sales instead of value added, and using wage bill instead of employment. The policy impact on the change in TFP (column (9) specification) remains positive, large, and significant across these TFP measures. ${ }^{62}$

These results in Table 8 should be interpreted with caution. First, there are many missing values on accounting values of employment and sales as UK accounting regulations do not insist on these being reported for smaller and medium sized enterprises (as in the US). Second, our available panel ends in 2011 and so we will not capture all the long-run effects. Nevertheless, the results suggest that the policy effects other measures of size and productivity as well as innovation.

\footnotetext{
${ }^{60}$ We use a Cobb-Douglas in value added as a function of capital and employment. We estimate separate production functions for each two-digit industry across all firms in the FAME dataset across the 2000-2005 period.

${ }^{61}$ If we subtract imputed R\&D staff count from employment to net out the impact of the policy on raising R\&D, the effects are smaller but qualitatively similar. The effects in log terms (standard errors) on adjusted employment in 2010 and 2011 are $0.24(0.15)$ and $0.27(0.15)$.

${ }^{62}$ Examples of alternative TFP measures include (i) Solow-residual TFP calculated from value added, capital, and employment, (ii) Solow-residual TFP calculated from sales, capital, and employment, (iii) Olley-Pakes TFP calculated from sales, capital, and employment, and (iv) Olley-Pakes TFP calculated from sales, capital, and wage bill. The corresponding estimated policy impacts (standard errors) on the change in TFP are (i) 0.203 (0.123), (ii) 0.284 (0.130), (iii) $0.211(0.122)$, and (iv) $0.211(0.118)$.
} 


\subsection{How firms cluster around the threshold in later years}

As discussed in Section 3, we chose total assets in 2007 as our primary running variable to avoid potential endogenous sorting of firms across the threshold once the policy effective date was announced in 2008 . We test the validity of our primary running variable choice and our concern by performing the McCrary test for each year from 2006 to 2011, ${ }^{63}$ which estimates the discontinuity in firms' total asset distribution at the SME threshold of $€ 86 \mathrm{~m}$. The respective McCrary tests for 2006 and 2007 (Figure A3) confirm that firms did not manipulate their total assets to benefit from the SME scheme before $2008 .{ }^{64}$ On the other hand, there is some graphical evidence of firms' bunching right below the $€ 86 \mathrm{~m}$ from 2009 onward, which is most obvious in 2009 and 2011. Finally, Figure A4 pools together the two years before the policy change (2006-07) and Figure A5 the three years after the change (2009-11). Again, it is apparent from these graphs that endogenous sorting does seem to happen, but only from 2009 onward after the policy became effective.

\subsection{Exploiting other elements of the SME definition}

We also explored using other elements of SME definition (sales and employment) to estimate the impacts of the policy and R\&D and innovation outputs (Table A10). We must interpret this with caution because, as noted above, there are many missing values on sales and employment. Furthermore, we also find evidence that the asset criterion is more binding than the sales criterion. As a firm is considered an SME if it meets either the asset or the sales criterion, the asset criterion is binding only when the firm already fails the sales one and vice versa. The binding/non-binding ratio for the asset criterion is 0.36 , considerably higher than the binding/non-binding ratio of 0.20 for sales criterion (Figure A6). ${ }^{65}$

As expected, while we still find positive effects on $R \& D$ and innovation outputs using the

\footnotetext{
${ }^{63}$ We exclude 2008 as the increase in deduction rate for large companies became effective before the effective date for the changes in the SME scheme (including increase in deduction rate for SMEs and SME definition change) was announced much later in the year. As such, it is hard to predict which way the bunching would happen in this year, or if it would happen at all.

${ }^{64}$ This is the log difference in density height at the SME threshold. The coefficient (standard error) is $0.029(0.065)$ in 2006 and $-0.026(0.088)$ in 2007.

${ }^{65}$ Binding/non-binding ratio for the asset criterion is calculated as number of firms with sales in 2007 between $€ 100 \mathrm{~m}$ and $€ 180 \mathrm{~m} /$ number of firms with sales in 2007 between $€ 20 \mathrm{~m}$ and $€ 100 \mathrm{~m}$, conditioned on firms' total assets in 2007 being between $€ 36 \mathrm{~m}$ and $€ 136 \mathrm{~m}$ (i.e. $+/-€ 50 \mathrm{~m}$ window around the asset threshold of $€ 86 \mathrm{~m}$ ). Binding/non-binding ratio for the sales criterion is calculated as the number of firms with total assets in 2008 between $€ 6 \mathrm{~m}$ and $€ 86 \mathrm{~m} / \mathrm{num}$ ber of firms with total assets in 2007 between $€ 86 \mathrm{~m}$ and $€ 166 \mathrm{~m}$, conditioned on firms' sales in 2007 being between $€ 50 \mathrm{~m}$ and $€ 150 \mathrm{~m}$ (i.e. $+/-€ 50 \mathrm{~m}$ window around the sales threshold of $€ 100 \mathrm{~m}$ ). The qualitative result that the asset criterion is more binding than the sales criterion does not change when we pick different windows to calculate the binding/non-binding ratios.
} 
sales or employment criterion (Table A10) but these effects are not always statistically significant. They are also of smaller magnitude compared to our baseline effects estimated using the asset criterion when taking into consideration the baseline R\&D and patent count of the respective sample. The treatment effect to baseline ratios for R\&D using asset, sales, and employment criteria are 1.92, 1.27, and 0.39 respectively, and the same set of ratios for patent count are $1.22,0.42$, and 0.85. ${ }^{66}$ We also examined whether combining the different SME criteria could increase the efficiency of our estimates, but found no significant improvement. ${ }^{67}$

\section{R\&D technology spillovers}

The main economic rationale usually given for more generous tax treatment of R\&D is that there are technological externalities, so the social return to $R \& D$ exceeds the private return. Our design allows us to estimate the causal impact of tax policies on R\&D spillovers, i.e. the innovation of other firms. Following the work of Jaffe (1986) we calculate the knowledge spillover pool available to firm $i$ as SpilltechRD $D_{i, 09-11}=\sum_{j \neq i} \omega_{i j} r d_{j, 09-11}$ where $r d_{j, 09-11}$ is the average R\&D of firm $j$ over 2009-11 and $\omega_{i j}$ is measure of technological "proximity" between firms $i$ and $j$ as indicated by which technology classes a firm patents in (e.g. if two firms have identical distributions of patent classes then proximity is 1 and if they are in entirely different patent classes the proximity is zero) ${ }^{68}$ We follow our earlier approach of using $E_{j, 2007}$ as instrument for $r d_{j, 09-11}$ where $E_{j, 2007}$ is the below-asset-threshold dummy in 2007 for firm $j .{ }^{69}$ Consequently, we construct

\footnotetext{
${ }^{66}$ Even when we restrict the sample to firms for which the sales criterion binds when using the sales running variable, the percentage effects are still lower than our baseline results, and are not statistically significant.

${ }^{67}$ The asset threshold almost always generates large and statistically significant effects on both R\&D and patents, while the sales threshold does not (columns (1)-(2) and (4)-(5) in Panel B of Table A10). Joint F-statistics for belowasset-threshold dummy and below-sales-threshold dummy indicate that their effects on both R\&D and innovation outputs are jointly significant in all cases. Finally, the estimated effects of R\&D on innovation outputs using both criteria as instrumental variables for $R \& D$ are of similar magnitude to our baseline effect of 0.530 ( 0.698 and 0.410 in columns (3) and (6) respectively). However, these estimates are less precise due to the inclusion of an additional weak belowsales-threshold dummy instrument.

${ }^{68}$ Following Jaffe (1986) we define proximity as the uncentered angular correlation between the vectors of the proportion of patents taken out in each technology class $\omega_{i j}=\frac{F_{i} F_{j}^{\prime}}{\left(F_{i} F_{i}^{\prime}\right)^{\frac{1}{2}}\left(F_{j} F_{j}^{\prime}\right)^{\frac{1}{2}}} . F_{i}=\left(F_{i 1}, \ldots, F_{i \Upsilon}\right)$ is a $1 \times \Upsilon$ vector where $F_{i \tau}=\frac{n_{i \tau}}{n_{i}}$ is firm $i$ 's number of patents in technology field $\tau$ as a share of firm $i$ 's total number of patents. To calculate $F_{i \tau}$, we use information on all patents filed between 1900 and 2011 (80\% of these patents are filed after 1980) and their 3-digit International Patent Classification (IPC), which classifies patents into 123 different technology fields. These data are available from PATSTAT. Bloom et al. (2013) show that the Jaffe measure delivers similar results to more sophisticated measures of proximity.

${ }^{69}$ More generally, $E_{i, 2007}=I\left\{z_{i, 2007} \leq \tilde{z}\right\}$ is a binary indicator equal to one if the 2007 financial variable $z_{i, 2007}$ is equal to or less than the corresponding new SME threshold for it, $\tilde{z}$.
} 
SpilltechSME $_{i, 09-11}=\sum_{j \neq i} \omega_{i j} E_{j, 2007}$ as instrument for SpilltechRD $D_{i, 09-11 .}$ The exclusion restriction requires that the discontinuity-induced random fluctuations in firm $j$ 's eligibility would only affect connected firm $i$ 's R\&D and innovation outputs through R\&D spillovers.

Our main spillover IV regression estimates the impact of SpilltechRD $D_{i, 09-11}$ on firm $i$ 's innovation, pat $t_{i, 09-11}$, controlling for firm $i$ 's own R\&D using $E_{i, 2007}$ as an instrument for it:

$$
\begin{array}{r}
\text { pat }_{i, 09-11}=\alpha_{4}+\delta \text { spilltechRD } D_{i, 09-11}+G_{i}\left(z_{2007}\right)+\theta E_{i, 2007}+f_{4}\left(z_{i, 2007}\right)+\lambda \times \\
\text { techconnect }_{i}+\varepsilon_{4 i}
\end{array}
$$

where $G_{i}\left(z_{2007}\right)=\sum_{j \neq i} \omega_{i j} g\left(z_{j, 2007}\right)$ and $\boldsymbol{z}_{2007}$ is a vector comprising of the 2007 assets for all firms; $f_{4}\left(z_{i, 2007}\right)$ and $g\left(z_{j, 2007}\right)$ are polynomials of firms $i$ and $j$ 's total assets in 2007; and techconnect $_{i}=\sum_{j \neq i} \omega_{i j}{ }^{70}$ We instrument spilltechRD $D_{i, 09-11}$ with spilltechSME $E_{i, 2007}$. $G_{i}\left(\mathbf{z}_{2007}\right)$ and $f_{4}\left(z_{i, 2007}\right)$ are polynomial controls for spilltechSM $E_{i, 2007}$ and $E_{i, 2007}$ respectively while techconnect $t_{i}$ additionally controls for firm $i$ 's level of "connectivity" in technology space. We estimate equation (4) on the sample of firms with total assets in 2007 between $€ 51 \mathrm{~m}$ and $€ 121 \mathrm{~m}$. This is a larger bandwidth than in the baseline sample as the policy-induced R\&D can have spillovers on firms well beyond the policy threshold. ${ }^{71}$ Standard errors are bootstrapped using 1,000 replications over firms.

Column (1) of Table 9 reports the first stage for the R\&D spillover term and column (2) the first stage for own R\&D. As expected the instrument spilltechSME $E_{i, 2007}$ significantly predicts spilltechR $D_{i, 09-11}$, in the first column and the instrument $E_{i, 2007}$ significantly predicts firm $i$ 's R\&D expenditure in the second column. The instruments spilltechSM $E_{i, 2007}$ and $E_{i, 2007}$ are

\footnotetext{
${ }^{70}$ Given an RD Design equation for firm $j$ 's R\&D as $r d_{j, 09-11}=\alpha+\beta_{F S} E_{j, 2007}+g\left(z_{j, 2007}\right)+\varepsilon_{j}$, aggregating across all connected firm $j$ 's around the SME asset threshold and using $\omega_{i j}$ as weights gives $\sum_{j \neq i} \omega_{i j} r d_{j, 09-11}=$ $\alpha \sum_{j \neq i} \omega_{i j}+\beta_{F S} \sum_{j \neq i} \omega_{i j} E_{j, 2007}+\sum_{j \neq i} \omega_{i j} g\left(z_{j, 2007}\right)+\sum_{j \neq i} \omega_{i j} \varepsilon_{j}$. Rewritten as spilltechRD $D_{i, 09-11}=\alpha \sum_{j \neq i} \omega_{i j}+$ $\beta_{F S}$ SpilltechSM $E_{i, 2007}+G_{i}\left(\mathbf{z}_{2007}\right)+\eta_{i}$, this equation shows that $G_{i}\left(\mathbf{z}_{2007}\right)$ is the appropriate polynomial control when using spilltechSME $E_{i, 2007}$ as instrument for spilltechRD $D_{i, 2007}$. The key condition that $\eta_{i}=\sum_{j \neq i} \omega_{i j} \varepsilon_{j}$ is mean independent of spilltechSM $E_{i, 2007}$ conditional on $G_{i}\left(\mathbf{z}_{2007}\right)$ follows from RD Design results. To address non-trivial serial correlation among the error term $\eta_{i}=\sum_{j \neq i} \omega_{i j} \varepsilon_{j}$, we correct the standard errors using 1,000 bootstrap replications over firms.

${ }^{71}$ Note that spilltechR $D_{i, 09-11}$ is calculated using the population of all possible firm $j$ 's, while spilltechSM $E_{i, 2007}$ and $G\left(z_{j, 2007}\right)$ are calculated using all firm $j$ 's with total assets in 2007 between $€ 51 \mathrm{~m}$ and $€ 121 \mathrm{~m}$ (same as the sample on which we estimate equation (4)), as the RD Design works best in samples of firms around the relevant threshold. Our key results are robust to using different sample bandwidths around the threshold to calculate spilltechSM $E_{i, 2007}$ and/or to estimate equation (4), as reported in foot note 73. In addition, in all reported results, we use second order polynomial controls separately on each side of the threshold for $g\left(z_{j, 2007}\right)$ and $f_{4}\left(z_{i, 2007}\right)$. In this larger sample we found that higher order terms were significant (unlike in the earlier Tables on smaller samples). However, using different orders of polynomial controls does not change our qualitative findings.
} 
jointly statistically different from zero in both columns, with F-statistics of 26.9 in column (1) and 6.4 in column (2). Interestingly, we see that in the reduced form patent model of column (3) the R\&D spillover instrument spilltechSME $E_{i, 2007}$ has a large and significant positive effect on firm $i$ 's patents. This is consistent with the tax policy generating sizeable spillover effect on innovation.

Turning to the IV results column (4) shows that there appears to be no significant effect of other firms' R\&D on own R\&D. By contrast, the implementation of our main IV specification of equation (4) in column (5) shows that R\&D by a firm's technological neighbors (spilltechRD $\left.D_{i, 09-11}\right)$ does have a causal impact on patenting consistent with the patent reduced form of column (4). This includes the instrument for own R\&D as a control in addition to the instrumented spillover term. Column (6) also instruments own R\&D and thus is a very demanding specification. Even though the spillover coefficient is no longer significant, ${ }^{72}$ its magnitude is almost identical in both specifications.

In terms of magnitudes, the last two columns suggests that a $£ 1 \mathrm{~m}$ increase in R\&D by a firm with an identical technological profile will increase patenting by 0.016 , which is $3.8 \%$ of the direct effect of an equivalent $R \& D$ increase by the firm itself $(=0.016 / 0.416)$. Combining this with the mean level of connectivity among firms in the sample gives us the total spillover effect of 0.704 $(=0.016 \times 44)$. In other words, the total spillovers of $£ 1 \mathrm{~m}$ increase in R\&D on all technologyconnected firms' patenting is about 1.7 times $(=0.704 / 0.416)$ the direct effect on own patenting. ${ }^{73}$

This presence of positive $R \& D$ spillovers on innovations is robust to a wide range of robustness tests. Focusing on the column (3) reduced form, if we limit our sample to only patenting firms, the coefficient (standard error) of the R\&D spillover instrument spilltechSME $E_{i, 2007}$ on patenting is $0.185(0.079)$, compared to $0.183(0.079)$ in Table 9. Second, the effect is present in both EPO and UK patent outcomes, with coefficients (standard errors) of 0.108 (0.048) and 0.157 (0.090) respectively. Third, the effect remains strong when we use the more sophisticated Mahalonobis generalization of the Jaffe proximity measure to allow for between field overlap (see Bloom et al. 2013), with coefficient (standard error) of 0.173 (0.080). Fourth, to address concern that patenting behavior after 2008 could be endogenous to the policy change, we reconstruct our standard Jaffe

\footnotetext{
72 If we use robust standard errors instead of bootstrapped standard errors, the estimated coefficient (standard error) for spilltechR $D_{i, 09-11}$ from column (6)'s specification is $0.016(0.008)$, statistically significant at $10 \%$ level.

${ }^{73}$ Consider a firm $j$ that increases its R\&D by $£ 1 \mathrm{~m}$. The spillover of this R\&D increase on a firm $i$ 's patenting, as estimated by equation (4), is $\delta \omega_{j i}$. Summing this spillover over all technology-connected firms' patenting gives total spillovers of $\delta \sum_{i, i \neq j} \omega_{j i}$, which is the product of the spillover coefficient and firm $j$ ' level of connectivity. The estimated total spillover effect for an average firm $\mathrm{j}$ is then $\hat{\delta} \overline{\sum_{l, l \neq j} \omega_{\jmath l}}=0.016 \times 44=0.704$.
} 
measure of technological proximity using only information on patents filed up to 2008 . The resulting spillover effect (standard error) is 0.199 (0.086). Fifth, the effect is robust to using smaller or large sample (by narrowing or widening the sample bandwidth around the asset threshold) to calculate the instrument spilltechSME $E_{i, 2007}$ or to estimate the spillover effect. ${ }^{74}$

In addition to equation (4), we also employ an alternative "dyadic" specification to estimate R\&D spillovers on innovations:

$$
\text { pat }_{i, 09-11}=\alpha_{5}+\kappa E_{j, 2007}+g_{5}\left(z_{j, 2007}\right)+\zeta E_{i, 2007}+f_{5}\left(z_{i, 2007}\right)+\varepsilon_{5 i j}
$$

where each observation is a pair of firm $i$ and firm $j$ that share the same main technology field (the technology field in which the firm files the most patents). ${ }^{75}$ In this specification, we are interested in the spillover effect of firm $j$ 's R\&D instrument $E_{j, 2007}$ on firm $i$ 's patents, controlling for firm $i$ 's own R\&D instrument $E_{i, 2007}$ and polynomials of firm $j$ 's and firm $i$ 's total assets. Similar to above, we focus on the sample in which both firm $i$ and firm $j$ have total assets between $€ 51 \mathrm{~m}$ and $€ 121 \mathrm{~m}$. The resulting estimate (standard error) for the spillover over is also positive, large, and statistically significant at $0.098(0.049) .{ }^{76}$ This effect is robust to using EPO and UK patent outcomes, narrowing or widening the sample for firm $i$ and firm $j$, and constructing firm $i$-firm $j$ pairs based on the firms' technological proximity instead of their main technology field. ${ }^{77}$ The results from this complementary "dyadic" spillover specification are qualitatively consistent with the findings from our main spillover specifications, thus further confirming the presence of R\&D spillovers on innovations.

Besides spillovers in technology space, there may be some negative R\&D spillovers through business stealing effects among firms in similar product markets. To address this concern, we follow Bloom et al. (2013) and construct spillsicR $D_{i, 09-11}=\sum_{j \neq i} \phi_{i j} r d_{j, 09-11}$ that captures the

\footnotetext{
${ }^{74}$ If we narrow the sample used to calculate the instrument spilltechSME $E_{i, 2007}$ to firms with total assets between $€ 61 \mathrm{~m}$ and $€ 111 \mathrm{~m}$ or between $€ 71 \mathrm{~m}$ and $€ 101 \mathrm{~m}$, the corresponding spillover effects (standard errors) are $0.103(0.072)$ and $0.220(0.109)$. If we narrow (widen) the sample for both calculating the instrument and estimating the spillover effect to firms with total assets between $€ 56 \mathrm{~m}$ and $€ 116 \mathrm{~m}$ (between $€ 46 \mathrm{~m}$ and $€ 126 \mathrm{~m}$ ), the corresponding spillover effects (standard errors) are $0.137(0.085)$ and $0.209(0.079)$.

${ }^{75} \mathrm{~A}$ firm's main technology field is defined at 3-digit IPC level using information on all patents filed between 1900 and 2008. We exclude patents filed after 2008 and firms patenting only after 2008 due to concern that patenting behavior after 2008 could be endogenous to the policy change, thus leading to endogenous sample selection.

${ }^{76}$ The corresponding specification includes second order polynomial controls separately on each side of the threshold for both firm $i$ and firm $j$. Standard errors are clustered by firm $i$ and firm $j$ 's common main technology field. Result is robust to using different orders of polynomial controls and to double clustering standard errors by firm $i$ and firm $j$. ${ }^{77}$ The estimated spillover effect (standard error) on EPO patents is $0.055(0.031)$, on UK patents is $0.122(0.066)$, when narrowing (widening) the sample to firms with total assets between $€ 56 \mathrm{~m}$ and $€ 116 \mathrm{~m}$ (between $€ 46 \mathrm{~m}$ and $€ 126 \mathrm{~m})$ is $0.071(0.074)(0.200(0.065))$. If we construct firm $i$-firm $j$ pairs as those with technological proximity not less than 0.25 or 0.5 , the corresponding spillover effects (standard errors) are $0.206(0.106)$ and $0.232(0.115)$.
} 
$\mathrm{R} \& \mathrm{D}$ spillovers in product market space, where $\phi_{i j}$ is a measure of product market distance between firms $i$ and $j .{ }^{78}$ We also construct spillsicSM $E_{i, 2007}=\sum_{j \neq i} \phi_{i j} E_{i, 2007}$ as instrument for spillsicR $D_{i, 09-11}$. We found no significant effects of spillsic $R D_{i, 09-11}$ on either $\mathrm{R} \& \mathrm{D}$ or patents.

In summary, these findings provide evidence that policy-induced $R \& D$ have sizable positive impacts on not only R\&D performing firms but also other firms in similar technology areas, as measured by innovation outputs. This further supports the use of R\&D subsidies in the UK context.

\section{Conclusion}

Fiscal incentives for R\&D have become an increasingly popular policy of supporting innovation across the world. But little is known about whether these costly tax breaks causally raise innovation. We address this issue by exploiting a change in the UK R\&D tax regime in 2008 which raised the size threshold determining whether a firm was eligible for the more generous "SME" tax regime. This enables us to implement a RD Design and assess impact of the policy on R\&D and innovation (as measured by patenting). Using total assets in the pre-policy period of 2007 we show that there was no evidence of discontinuities around the threshold prior to the policy, which is unsurprising as the new threshold was only relevant for the R\&D tax incentive scheme and not for other programs targeting SMEs.

The policy caused an economically and statistically significant increase in R\&D and patenting, and there is no evidence that the new patenting was of significantly lower value. Hence R\&D tax policies do seem effective in increasing innovation, they are not simply devices for relabeling existing spending. The elasticity of $R \& D$ with respect to changes in its (tax adjusted) user cost is around 2.6. We argue that this is higher than existing estimates because we focus on firms that are smaller than those conventionally used in the extant literature and are more likely to be subject to financial constraints. The policy seems to be cost effective, in aggregate stimulating $£ 1.7$ of R\&D for every $£ 1$ of taxpayer subsidy. Over the 2006-2011 period we calculate that the tax scheme meant aggregate business R\&D was $10 \%$ higher than it would otherwise have been, halting the secular decline of the UK's share of business R\&D in GDP.

There are many caveats when moving from these results to policy. Although the results are optimistic about the efficacy of tax incentives, the large effects come from smaller firms and should not be generalized across the entire size distribution - this does imply that targeting R\&D policy

\footnotetext{
${ }^{78} \phi_{i j}=1$ if firm $i$ operates in the same industry as firm $j$ and $\phi_{i j}=0$ otherwise. To calculate $\phi_{i j}$, we use firms' primary industry codes at 3 -digit Standard Industry Classification (SIC). These data are available from FAME.
} 
on financially constrained SMEs is worthwhile (although a first best policy would be to deal directly with credit market imperfections).

We have partially examined general equilibrium effects by demonstrating that the R\&D tax policy stimulated patenting activity not only for the firms directly affected, but also created spillovers for other firms who were indirectly affected. However, there may be other equilibrium effects that reduce innovation. For example, subsidies are captured in the form of higher wages rather than a higher volume of $R \& D$, especially in the short-run. We believe that this is less likely to be a first order problem when there is large international mobility of inventors, as is the case in the UK (e.g. Akcigit, Baslandze and Stantcheva, 2015, and within the US see Moretti and Wilson, 2015). Finally, it is unclear if tax breaks are the optimal form of support for innovation. Direct support of basic $R \& D$ in the science base and increasing the supply of future talent into the innovation sector (e.g. Bell et al., 2015; Toivanen and Väänänen, 2016) are policies that may have more powerful effects on innovation and growth in the long term.

\section{References}

Akcigit, U., Baslandze, S. and Stantcheva, S. (2015) "Taxation and the international mobility of inventors." NBER Working Paper No. 21024.

Aghion, P. and Howitt, P. (1992) "A model of growth through creative destruction." Econometrica, 60(2) 323-351.

Angrist, J. and Imbens, G. (1995) "Two-Stage Least Squares Estimation of Average Causal Effects in Models with Variable Treatment Intensity." Journal of the American Statistical Association, 90(430) 431-442.

Arora, A., Ceccagnoli, M. and Cohen, W.M. (2008). "R\&D and the patent premium." International Journal of Industrial Organization, 26(6) 1153-1179.

Arrow, K. (1962) "Economic Welfare and Allocation of Resources for Invention." 609-626 in National Bureau of Economic Research, The Rate and Direction of Inventive Activity: Economic and Social Factors, Princeton, NJ: Princeton University Press.

Agrawal, A., Rosell, C. and Simcoe, T. S. (2014) "Do tax credits affect R\&D expenditures by small firms? Evidence from Canada.” NBER Working Paper No. 20615.

Azoulay, P., Graff Zivin, J. Li, D. and Sampat, B. (2015) "Public R\&D Investment and Private Sector Patenting: Evidence from NIH Funding Rules" NBER Working Paper No. 20889.

Becker, B. (2015) "Public R\&D policies and private R\&D investment: A survey of the empirical evidence." Journal of Economic Surveys, 29(5) 917-942

Bell, A., Chetty, R., Jaravel, X., Petkova, N. and J. Van Reenen (2015) "The lifecycle of inventors." Stanford mimeo.

Bérubé, C. and Mohnen, P. (2009) "Are Firms That Receive R\&D Subsidies More Innovative?" Canadian Journal of Economics 42 (1) 206-25.

Bloom, N., Griffith, R. and Van Reenen, J. (2002) "Do R\&D tax credits work? Evidence from 
a panel of countries 1979-1997." Journal of Public Economics, 85(1) 1-31.

Bloom, N., Schankerman, M. and Van Reenen, J. (2013) "Identifying technology spillovers and product market rivalry." Econometrica, 81(4) 1347-1393.

Blundell, R., Griffith, R. and Van Reenen, J. (1999). "Market share, market value and Innovation: Evidence from British Manufacturing Firms." Review of Economic Studies, (1999) 66(3), 228, 529-554.

Bøler, E., Moxnes, A. and Ulltveit-Moe, K. (2015). "R\&D, International Sourcing, and the Joint Impact on Firm Performance." American Economic Review, 105(12) 3704-3729.

Bond, S. and Guceri, I. (2012) "Trends in UK BERD after the introduction of R\&D tax credits." Oxford University Center for Business Taxation Working Paper No. 2012/01.

Branstetter, L. and Sakakibara, M. (2002) "When Do Research Consortia Work Well and Why? Evidence from Japanese Panel Data." American Economic Review, 92(1) 143-59.

Bronzini, R. and Iachini E. (2014) "Are incentives for R\&D effective? Evidence from a regression discontinuity approach." American Economic Journal: Economic Policy, 6(4) 100-134.

Bronzini, R. and Piselli, P. (2014) "The Impact of R\&D Subsidies on Firm Innovation" Bank of Italy Economic working papers.

Cameron, G. (1996) "On the measurement of real R\&D: Divisia price indices for UK business enterprise R\&D." Research Evaluation, 6(3) 215-219.

Cappelen, Å, Raknerud, A. and Rybalka, M. (2012) "The Effects of R\&D Tax Credits on Patenting and Innovations." Research Policy 41 (2) 334-45.

Corrado, C., Haskel, J., Jona-Lasinio, C. and Nasim, B. (2015) "Is international tax competition a zero sum game", Imperial College mimeo.

Czarnitzki, D., Hanel, P. and Rosa, J.M. (2011) "Evaluating the impact of R\&D tax credit on innovation: A micro-econometric study on Canadian firms." Research Policy, 40(2011) 217-229.

David, P., Hall, P. and Toole A. (2000) "Is public R\&D a complement or substitute for Private R\&D? A review of the econometric evidence." Research Policy, 29(4-5) 497-529.

Dechezleprêtre, A. (2013) "Fast-Tracking 'Green' Patent Applications: An Empirical Analysis" CEP Discussion Paper No 1197.

Dernis H., Dosso M., Hervás F., Millot V., Squicciarini M. and Vezzani A. (2015). "World Corporate Top R\&D Investors: Innovation and IP bundles." A JRC and OECD common report. Luxembourg: Publications Office of the European Union.

Einiö, E. (2014) "R\&D subsidies and company performance: Evidence from geographic variation in government funding based on the ERDF population-density rule." Review of Economics and Statistics, 96(4) 710-728.

Eisner, R., Albert, S. and Sullivan, M. (1986) "The new incremental tax credit for R\&D: Incentive or Disincentive?" National Tax Journal XXXVII, 171-83.

Finance Act 2000, 2002, 2007, London: HMSO.

Garicano, L., Lelarge, C. and Van Reenen, J. (2013) "Firm size distortions and the productivity distribution: Evidence from France." NBER Working Paper No. 18841.

Fowkes, R.K., Sousa, J. and Duncan, N. (2015) "Evaluation of research and development tax credit." HMRC Working Paper No. 17.

Gelman, A. and Imbens, G. (2014) "Why high-order polynomials should not be used in regression discontinuity designs.” NBER Working Paper No. 20405. 
González, X., Jamandreu, J. and Pazó C. (2005) "Barriers to innovation and subsidy effectiveness." RAND Journal of Economics, 36 930-950.

Goodridge, P., Haskel, J., Hughes, A. and Wallis, G. (2015) "The contribution of public and private R\&D to UK productivity growth." Imperial College Business School Working Paper No. 2015/03.

Goolsbee, A. (1998) "Does government R\&D policy mainly benefit scientists and engineers?" American Economic Review, 88(2) 298-302.

Griliches, Z. (1979) "Issues in assessing the contribution of research and development to productivity growth." Bell Journal of Economics, 10(1) 92-116.

Gucerci, I. (2015) "Will the real R\&D employees please stand up? Effects of tax break on firm level outcomes." Oxford University mimeo.

Gureci, I and Liu, L. (2015) "Effectiveness of fiscal incentives for R\&D: Quasi-experimental evidence" Oxford Centre for Business Taxation mimeo.

Guellec, D. and Van Pottelsberghe de la Potterie, B. (2004) "From R\&D to Productivity Growth: Do the Institutional Settings and the Source of Funds of R\&D Matter?" Oxford Bulletin of Economics and Statistics, 66(3) 353-378.

Gruber, J. (2011) Public Finance and Public Policy, Worth Publishers.

Gurmu, S. and Pérez-Sebastián, F. (2008) "Patents, R\&D and lag effects: Evidence from flexible methods for count panel data on manufacturing firms." Empirical Economics, 35(3) 507-526.

Hall, B. and Van Reenen, J. (2000) "How effective are fiscal incentives for R\&D? A review of the evidence." Research Policy, 29(4) 449-469.

Hall, B. and Ziedonis, R. (2001) "An empirical study of patenting in the U.S. semiconductor industry, 1979-1995." RAND Journal of Economics, 32(1) 101-128.

Hall, B. H., Jaffe, A. B., and Trajtenberg, M. (2005) "Market value and patent citations" RAND Journal of Economics, 16-38.

Hall, B., Mairesse, J. and Mohnen, P. (2010) "Measuring the returns to R\&D." Handbook of the Economics of Innovation. Vol. 2, Ch. 24 1033-1082. Elsevier.

Hall, B. H., Helmers, C., Rogers, M., and Sena, V. (2013) "The importance (or not) of patents to UK firms" Oxford Economic Papers, 65(3) 603-629.

Hall, R.E. and Jorgenson, D.W. (1967) "Tax policy and investment behavior." American Economic Review, 57(3) 391-414.

Harhoff, D., Scherer, F. M., and Vopel, K. (2003) "Citations, family size, opposition and the value of patent rights" Research Policy, 32(8) 1343-1363.

Hassett, K. and Hubbard, R.G. (2002) "Tax policy and business investment." Handbook of Public Economics. Vol. 3, Ch. 20, 1293-1343. Elsevier.

Hausman, J., Hall, B. and Griliches, Z. (1984) "Econometric models for count data with an application to the patents-R\&D relationship." Econometrica, 52 909-938.

HMRC (2014) "Research and Development Tax Credit Statistics." London.

Howell, Sabrina (2015) "Financing Constraints as a Barrier to Innovation", NYU mimeo.

Imbens, G. and Kalyanaraman, K. (2011) "Optimal bandwidth choice for the regression discontinuity estimator." Review of Economic Studies, 79(3) 933-959.

Jacob, B. and Lefgren, L. (2010) "The impact of research grant funding on scientific productivity." Journal of Public Economics, 95(9-10) 1168-1177.

Jaffe, A. (1986) “Technological Opportunities and Spillovers of R\&D: Evidence from firms' 
patents, profits and market value" American Economic Review, LXXVI, 984-1001.

Jaffe, A., Trajtenberg, M. and Henderson, R. (1993) "Geographic localization of knowledge spillovers as evidenced by patent citations” Quarterly Journal of Economics, 108 (3) 577-598.

Jaffe, A. and Lerner, J. (2004) Innovation and its Discontents, Princeton: Princeton University Press.

Jaffe, A. and Le, T. (2015) "The Impact of an R\&D subsidy on innovation: A study of New Zealand firms" NBER Working Paper 21479.

Kleven, H. and Waseem, M. (2013) "Using notches to uncover optimization frictions and structural elasticities: Theory and evidence from Pakistan." Quarterly Journal of Economics, 128(2) 669-723.

Lach, Saul (2002) "Do R\&D subsidies stimulate or displace private R\&D? Evidence from Israel” Journal of Industrial Economics, 50, 369-90.

Lanjouw, J., Pakes, A. and Putnam, J. (1998) "How to count patents and value intellectual property: The uses of patent renewal and application data." Journal of Industrial Economics, 46(4) 405-432.

Lee, D. (2008) "Randomized experiments from non-random selection in U.S. House elections." Journal of Econometrics, 142(2) 675-697.

Lee, D. and Lemieux. T. (2010) "Regression discontinuity designs in economics." Journal of Economic Literature, 48(2) 281-355.

Moretti, E. and Wilson, D. (2015) "The effect of state Taxes on the geographical location of top earners: Evidence from star scientists.” NBER Working Paper No. 21120.

Moretti, E., Steinwender, C., and Van Reenen, J. (2015) "The Intellectual Spoils of War? Defense R\&D, Productivity and International Technology Spillovers", LSE mimeo.

Olley, S. and A. Pakes (1996) 'The Dynamics of Productivity in the Telecommunications Equipment Industry’ Econometrica, 64(6) 263-1297.

OECD (2013) Survey of $R \& D$ tax credits, Paris: OECD.

OECD (2014) "Trends in R\&D tax generosity and potential loss of predictability in tax regimes, 2001-11." OECD Science, Technology and Industry Outlook 2014, Paris: OECD.

Rao, N. (2015) "Do tax credits stimulate R\&D spending? Revisiting the effect of the R\&D tax credit in its first decade." Forthcoming, Journal of Public Economics.

Roland Berger, 2005. "The Cost of a Sample European Patent-New Estimates" Roland Berger Market Research, Munich.

Romer, P. (1990) "Endogenous technological change." Journal of Political Economy, 98(5) 71-102.

Takalo, T., Tanayama. T. and Toivanen, O. (2013) "Estimating the Benefits of Targeted R\&D Subsidies." Review of Economics and Statistics, 95, 255-272.

Toivanen, O., and Väänänen, L. (2016) "Education and Invention." Review of Economics and Statistics, vol. 98, no. 2, pp. 382 - 396.

Wallsten, S. (2000) "The effects of government-industry R\&D programs on private R\&D: The case of the Small Business Innovation Research program." RAND Journal of Economics, 31, 82-100.

Wilson, D. (2009) "Beggar thy neighbor? The in-state, out-of-state and aggregate effects of R\&D tax credits." Review of Economics and Statistics, 91(2) 431-436. 


\section{Figure 1. McCrary test for no manipulation at the SME asset threshold in 2007}

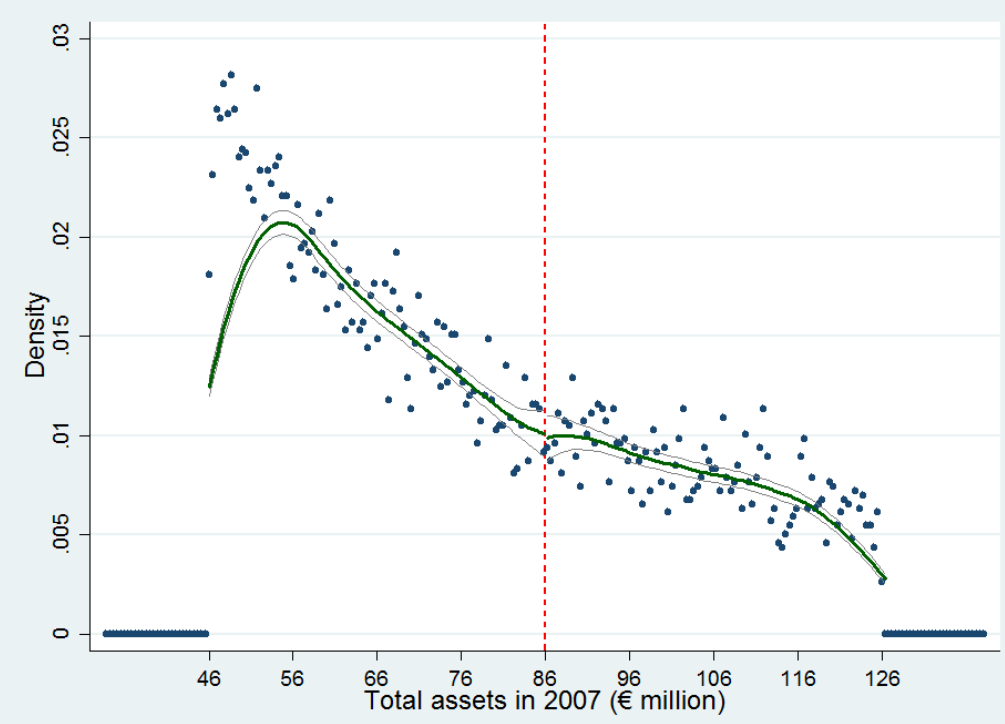

Note: McCrary test for discontinuity in distribution density of total assets in 2007 at the SME asset threshold of $€ 86 \mathrm{~m}$. Sample includes firms with total assets in 2007 between $€ 46 \mathrm{~m}$ and $€ 126 \mathrm{~m}$. The discontinuity estimate (log difference in density height at the SME threshold) is -0.026 , with standard error of 0.088 .

\section{Figure 2. Discontinuity in average R\&D expenditure over 2009-11}

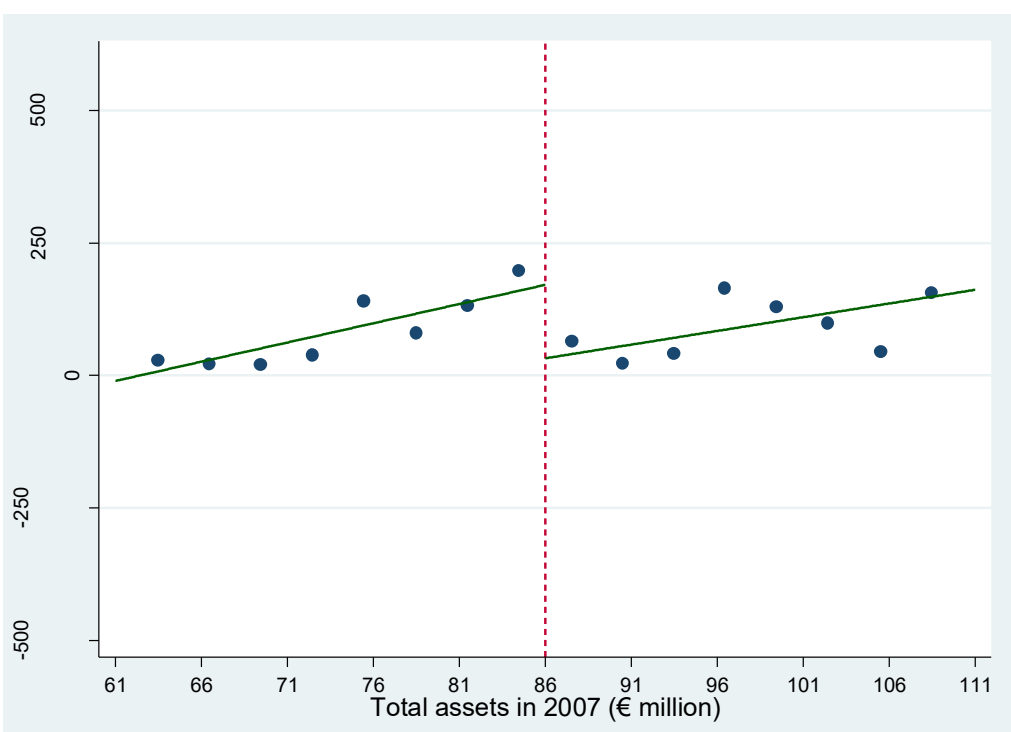

Note: The figure corresponds to the baseline R\&D expenditure regression using a Regression Discontinuity (RD) Design. The dependent variable is average R\&D expenditure over 2009-11. The running variable is total assets in 2007 with a threshold of $€ 86 \mathrm{~m}$. The baseline sample includes firms with total assets in $2007 € 25 \mathrm{~m}$ above and $€ 25 \mathrm{~m}$ below the cut-off (i.e. between $€ 61 \mathrm{~m}$ and $€ 111 \mathrm{~m}$ ). Controls for the running variable are estimated separately on each side of the threshold. The OLS discontinuity estimate at the $€ 86 \mathrm{~m}$ threshold is 138,540 with a standard error of 55,318. Bin size for the scatter plot is $€ 3 \mathrm{~m}$. 


\section{Figure 3. Discontinuity in average number of patents over 2009-11}

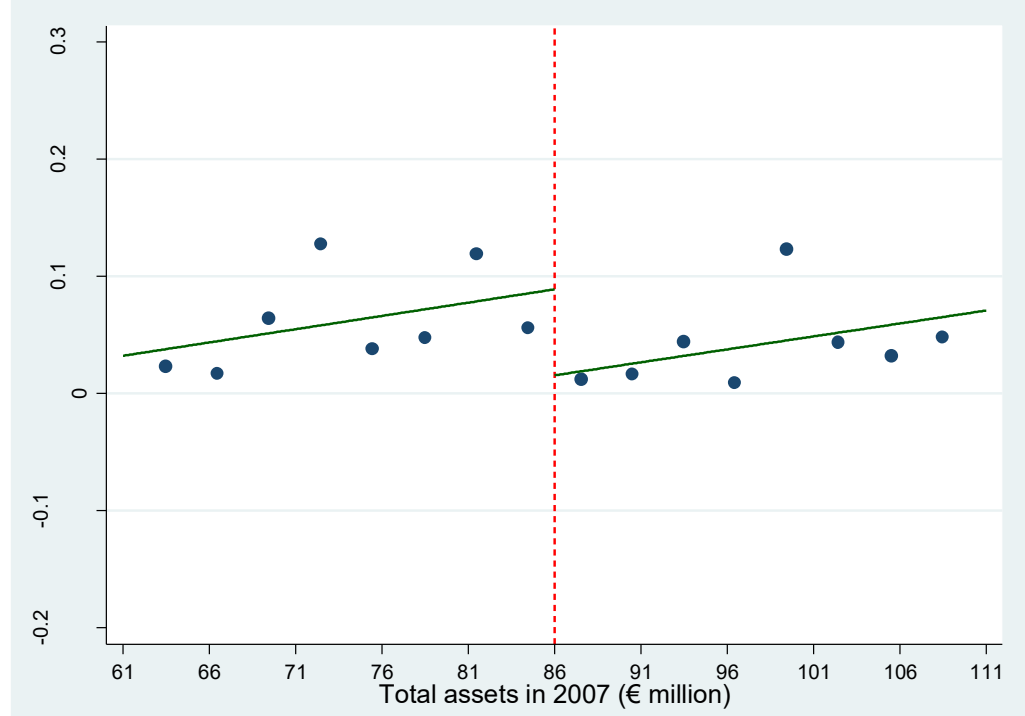

Note: The figure corresponds to our baseline reduced-form patent regression using an RD Design. The dependent variable is average number of patents over 2009-11. The running variable is total assets in 2007 with a threshold of $€ 86 \mathrm{~m}$. Baseline sample includes firms with total assets in $2007 € 25 \mathrm{~m}$ above and below the cut-off (i.e. between $€ 61 \mathrm{~m}$ and $€ 111 \mathrm{~m}$ ). Controls for running variable separately for each side of the threshold are included. The OLS discontinuity estimate at the $€ 86 \mathrm{~m}$ threshold is 0.073 with a standard error of 0.026 . Bin size for the scatter plot is $€ 3 \mathrm{~m}$.

\section{Figure 4. Business Enterprise R\&D over GDP, selected countries}

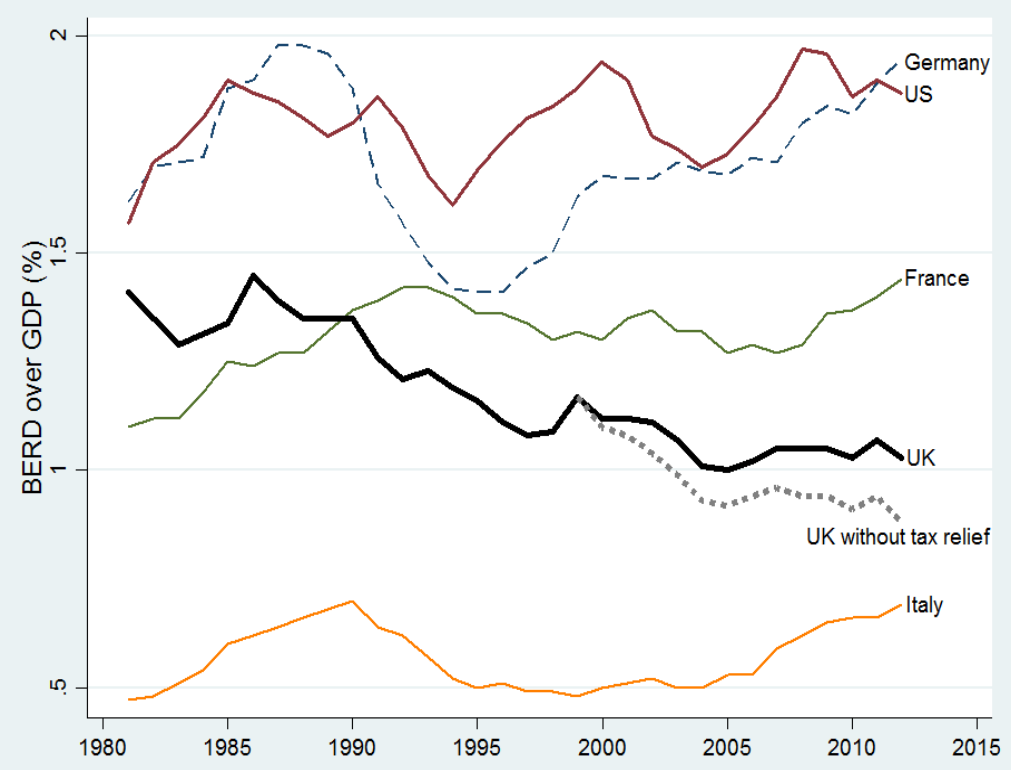

Note: The data is from OECD MSTI downloaded February $9^{\text {th }}$ 2016. The dotted line ("UK without tax relief") is the counterfactual R\&D intensity in the UK that we estimate in the absence of the R\&D Tax Relief Scheme (see subsection 5.3 and Appendix A.5 for details). 
Table 1. Baseline sample descriptive statistics

\begin{tabular}{|c|c|c|c|c|c|c|c|c|c|c|c|c|c|c|c|}
\hline \multirow{2}{*}{$\begin{array}{l}\text { Sample } \\
\text { Year }\end{array}$} & \multicolumn{8}{|c|}{$\begin{array}{c}\text { Firms with total assets in } 2007 \\
\text { between } € 61 \mathrm{~m} \text { and } € 86 \mathrm{~m}\end{array}$} & \multicolumn{7}{|c|}{$\begin{array}{c}\text { Firms with total assets in } 2007 \\
\text { between } € 86 \mathrm{~m} \text { and } € 111 \mathrm{~m}\end{array}$} \\
\hline & 2006 & 2007 & 2008 & 2009 & 2010 & 2011 & $\begin{array}{c}06-08 \\
\text { avg. }\end{array}$ & $\begin{array}{c}09-11 \\
\text { avg. }\end{array}$ & 2006 & 2007 & 2008 & 2009 & 2010 & 2011 & $\begin{array}{cc}06-08 & 09-11 \\
\text { avg. } & \text { avg. }\end{array}$ \\
\hline Total no. firms in the subsample & \multicolumn{8}{|c|}{3,561} & \multicolumn{7}{|c|}{2,327} \\
\hline Mean qual. $R \& D$ exp. $(£ ' 000)$ & 50.0 & 70.9 & 52.6 & 68.9 & 71.8 & 75.3 & 57.8 & 72.0 & 87.1 & 110.6 & 85.7 & 100.5 & 91.9 & 88.4 & $94.5 \quad 93.6$ \\
\hline Mean patents & 0.065 & 0.059 & 0.060 & 0.060 & 0.058 & 0.056 & 0.061 & 0.058 & 0.056 & 0.066 & 0.053 & 0.041 & 0.040 & 0.044 & $0.058 \quad 0.042$ \\
\hline Mean UK patents & 0.078 & 0.084 & 0.078 & 0.072 & 0.067 & 0.070 & 0.080 & 0.070 & 0.062 & 0.081 & 0.074 & 0.056 & 0.045 & 0.050 & $0.072 \quad 0.050$ \\
\hline Mean EPO patents & 0.028 & 0.032 & 0.036 & 0.031 & 0.028 & 0.024 & 0.032 & 0.028 & 0.029 & 0.029 & 0.033 & 0.020 & 0.025 & 0.023 & $0.030 \quad 0.023$ \\
\hline
\end{tabular}

Note: The baseline sample includes 5,888 firms with total assets in 2007 between $€ 61 \mathrm{~m}$ and $€ 111 \mathrm{~m}$. Total assets are from FAME and are converted to $€$ from $£$ using HMRC rules. Qualifying R\&D expenditure comes from CT600 panel dataset and are converted to 2007 prices. Patent counts come from PATSTAT.

Table 2. R\&D regressions
(1)
(2)
(3)
(4)
(5)
(6)
(7)
(8)
(9)

\section{Dependent variable}

R\&D expenditure ( $f$ '000)

\begin{tabular}{|c|c|c|c|c|c|c|c|c|c|}
\hline \multirow[b]{2}{*}{ Year } & & & \\
\hline & 2006 & 2007 & 2008 & 2009 & 2010 & 2011 & $\begin{array}{l}2006-08 \\
\text { average }\end{array}$ & $\begin{array}{l}2009-11 \\
\text { average }\end{array}$ & After - Before \\
\hline Below asset threshold & 61.5 & 96.1 & 32.0 & $120.7 * *$ & $157.8 * * *$ & $137.2 * *$ & 63.2 & $138.5 * *$ & $75.3 * *$ \\
\hline dummy (in 2007) & $(58.5)$ & $(72.1)$ & $(40.4)$ & $(59.0)$ & $(58.6)$ & $(53.7)$ & $(53.4)$ & $(55.3)$ & $(36.3)$ \\
\hline Firms & 5,888 & 5,888 & 5,888 & 5,888 & 5,888 & 5,888 & 5,888 & 5,888 & 5,888 \\
\hline
\end{tabular}

Note: $* * *$ significant at $1 \%$ level, $* * 5 \%$ level, * $10 \%$ level. OLS estimates based on the RD Design. The running variable is total assets in 2007 with a threshold of $€ 86 \mathrm{~m}$. Baseline sample includes firms with total assets in 2007 within $€ 25 \mathrm{~m}$ below and above the cut-off (i.e. between $€ 61 \mathrm{~m}$ and $€ 111 \mathrm{~m}$ ). Controls for first order polynomials of the running variable separately for each side of the threshold are included. Robust standard errors are in brackets. Mean R\&D between 2006 and 2008 was £72,312 and between 2009 and 2011 was $£ 80,545.2007$ real prices. 
Table 3. Pre-treatment covariate balance tests and placebo tests

\begin{tabular}{|c|c|c|c|c|c|c|c|c|}
\hline \multirow{3}{*}{$\begin{array}{l}\text { Dependent variable } \\
\text { Year }\end{array}$} & (1) & (2) & (3) & (4) & (5) & (6) & $(7)$ & (8) \\
\hline & \multicolumn{2}{|c|}{ Ln(Sales) } & \multicolumn{2}{|c|}{ Ln(Employment) } & \multicolumn{2}{|c|}{ Ln(Capital) } & \multicolumn{2}{|c|}{ R\&D exp. (£'000) } \\
\hline & 2006 & 2007 & 2006 & 2007 & 2006 & 2007 & \multicolumn{2}{|c|}{ 2009-11 average } \\
\hline \multirow{2}{*}{$\begin{array}{l}\text { Below asset threshold dummy } \\
\text { (in 2007) }\end{array}$} & -0.124 & 0.086 & 0.118 & 0.151 & 0.020 & -0.007 & -16.5 & 48.6 \\
\hline & $(0.162)$ & $(0.161)$ & $(0.135)$ & $(0.131)$ & $(0.112)$ & $(0.103)$ & $(41.7)$ & $(77.1)$ \\
\hline SME threshold $(€)$ & $86 \mathrm{~m}$ & $86 \mathrm{~m}$ & $86 \mathrm{~m}$ & $86 \mathrm{~m}$ & $86 \mathrm{~m}$ & $86 \mathrm{~m}$ & $71 \mathrm{~m}$ & $101 \mathrm{~m}$ \\
\hline Sample bandwidth & $61-111 \mathrm{~m}$ & $61-111 \mathrm{~m}$ & $61-111 \mathrm{~m}$ & $61-111 \mathrm{~m}$ & $61-111 \mathrm{~m}$ & $61-111 \mathrm{~m}$ & $46-86 \mathrm{~m}$ & $86-126 \mathrm{~m}$ \\
\hline Firms & 4,155 & 4,348 & 2,973 & 3,091 & 4,763 & 5,079 & 7,095 & 3,354 \\
\hline
\end{tabular}

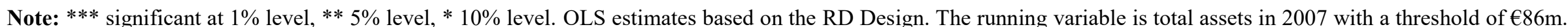

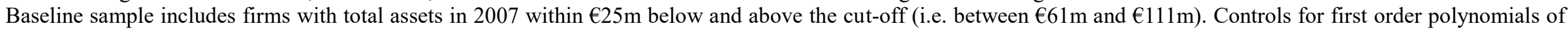

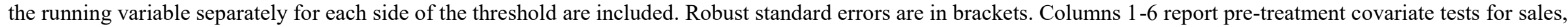
employment, and capital. Columns (7) and (8) report placebo tests using placebo asset threshold of $€ 71 \mathrm{~m}$ and $€ 101 \mathrm{~m}$.

Table 4: Reduced-form patent regressions

$(1)(3)+(3)$
(1)
(2)
(3)
(4)
(5)

(6)

(7)

(8)

(9)

All patent count

\begin{tabular}{|c|c|c|c|c|c|c|c|c|c|}
\hline \multirow[t]{3}{*}{ Dependent variable } & \multicolumn{9}{|c|}{ All patent count } \\
\hline & \multicolumn{3}{|c|}{ Before (pre-policy) } & \multicolumn{3}{|c|}{ After (post-policy) } & \multirow{2}{*}{$\begin{array}{c}\text { Before } \\
2006-08 \\
\text { average }\end{array}$} & \multirow{2}{*}{$\begin{array}{c}\text { After } \\
2009-11 \\
\text { average }\end{array}$} & \multirow{2}{*}{$\begin{array}{c}\text { Difference } \\
\text { After - Before }\end{array}$} \\
\hline & 2006 & 2007 & 2008 & 2009 & 2010 & 2011 & & & \\
\hline Below asset threshold & 0.026 & 0.043 & 0.045 & $0.081 * * *$ & $0.066 * *$ & $0.074 * *$ & 0.038 & $0.073 * * *$ & $0.035 *$ \\
\hline dummy (in 2007) & $(0.028)$ & $(0.030)$ & $(0.032)$ & $(0.029)$ & $(0.027)$ & $(0.031)$ & $(0.027)$ & $(0.026)$ & $(0.020)$ \\
\hline Firms & 5,888 & 5,888 & 5,888 & 5,888 & 5,888 & 5,888 & 5,888 & 5,888 & 5,888 \\
\hline
\end{tabular}

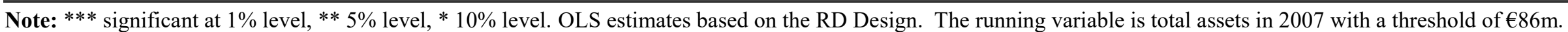

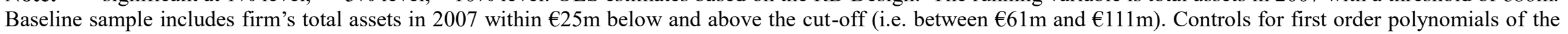

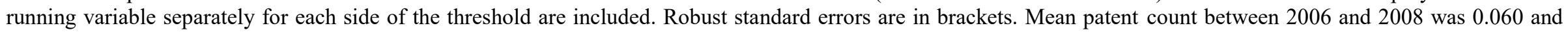
between 2009 and 2011 was 0.052 . 
Table 5: The effects of R\&D tax policy on quality-adjusted patents

(1)
(3)
(4)

$(5)$

amily size Granted

(i.e. countries) patents
(6)

Chemistry/ pharma patents

$0.024 *$

$(0.085)$

$0.027 * *$

Below asset threshold

(0.016)

(0.033)

0.222

(0.012)

(0.014)

0.036

5,888

5,888
0.015

5,888
Firms

5,888

5,888

5,888
(7)

Nonchem/pharma patents

$0.050 * *$

(0.022)

0.045

5,888
(8)

(9)

EPO patent UK patent citations citations

$0.004 * *$

0.023

(0.002)

(0.021)

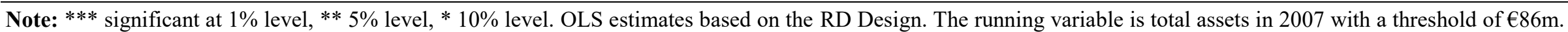

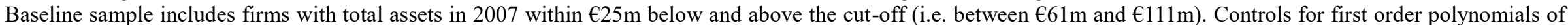

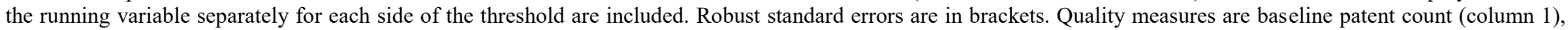

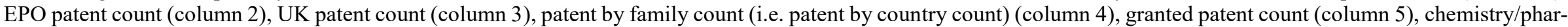

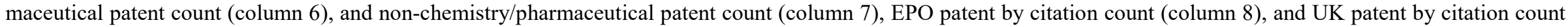
(column 9).

\section{Table 6. Effects of R\&D on patents (IV regressions)}
(1)
(2)
(3)
(4)

(5)

(6)

\section{Dependent variable} (2009-11 average)

All patent count

Specification

R\&D expenditure (£ million),

2009-11 average

Anderson-Rubin test p-value

Hausman test p-value

OLS

$(0.074)$

Firms
EPO patent count

\begin{tabular}{cc}
\hline OLS & IV \\
\hline $0.094^{* *}$ & $0.268^{*}$ \\
$(0.04)$ & $(0.140)$
\end{tabular}

0.024

0.32
UK patent count

\begin{tabular}{|c|c|}
\hline OLS & IV \\
\hline $0.207 * *$ & $0.680^{* *}$ \\
\hline \multirow[t]{2}{*}{$(0.093)$} & $(0.327)$ \\
\hline & 0.004 \\
\hline \multicolumn{2}{|c|}{0.12} \\
\hline 5,888 & 5,888 \\
\hline
\end{tabular}

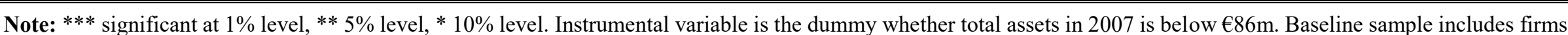

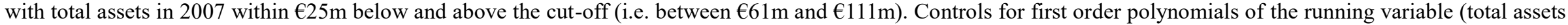

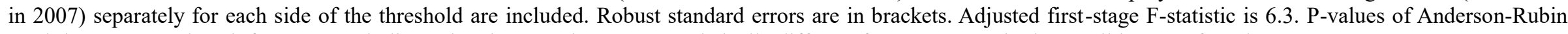
weak-instrument-robust inference tests indicate that the IV estimates are statistically different from zero even in the possible case of weak IV. 
Table 7. Heterogeneous effects of R\&D Tax policy by firm age (as proxies for financial constraints)

\begin{tabular}{|c|c|c|c|c|c|c|c|c|}
\hline & (1) & (2) & (3) & (4) & (5) & (6) & (7) & (8) \\
\hline Dependent variable & \multicolumn{8}{|c|}{ R\&D expenditure ( $£$ '000) } \\
\hline Year & \multicolumn{2}{|c|}{ After (2009-11 average) } & \multicolumn{2}{|c|}{ After - Before } & \multicolumn{2}{|c|}{ After (2009-11 average) } & \multicolumn{2}{|c|}{ After - Before } \\
\hline Subsample & Young firms & Old firms & Young firms & Old firms & $\begin{array}{c}\text { Young firms \& } \\
\text { profits }>0\end{array}$ & $\begin{array}{l}\text { Old firms \& } \\
\text { profits }>0\end{array}$ & $\begin{array}{l}\text { Young firms } \\
\& \text { profits }>0\end{array}$ & $\begin{array}{c}\text { Old firms \& } \\
\text { profits }>0\end{array}$ \\
\hline $\begin{array}{l}\text { Below asset threshold } \\
\text { dummy } \\
\text { (in 2007) }\end{array}$ & $\begin{array}{l}92.3 * * \\
(42.1)\end{array}$ & $\begin{array}{l}198.4 * \\
(104.2)\end{array}$ & $\begin{array}{l}97.9 * * \\
(42.2)\end{array}$ & $\begin{array}{c}56.3 \\
(59.4)\end{array}$ & $\begin{array}{l}124.5 * \\
(70.0)\end{array}$ & $\begin{array}{c}107.7 \\
(120.7)\end{array}$ & $\begin{array}{l}111.0 \\
(93.2)\end{array}$ & $\begin{array}{c}46.0 \\
(79.6)\end{array}$ \\
\hline Mean over 2006-08 & 37.9 & 107.1 & & & 46.2 & 90.6 & & \\
\hline Mean after - before & & & 2.8 & 46.8 & & & -8.6 & 29.4 \\
\hline Firms & 2,928 & 2,955 & 2,928 & 2,955 & 956 & 1,585 & 956 & 1,585 \\
\hline
\end{tabular}

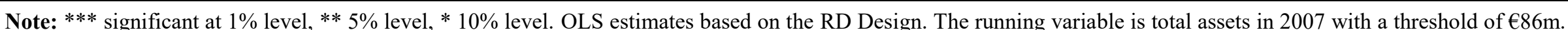

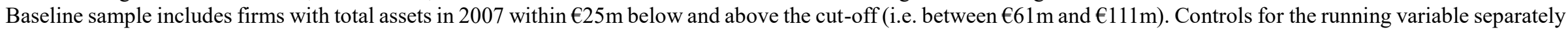

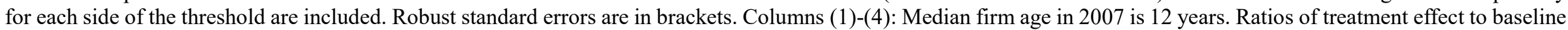

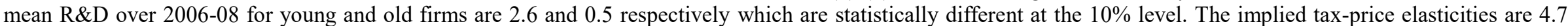

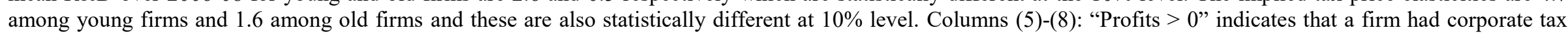

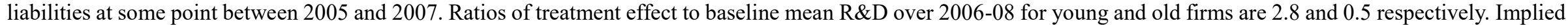
tax-price elasticities are 4.8 among young firms and 1.6 among old firms. 
Table 8. Effects of R\&D Tax Relief Scheme on other measures of firms performance

$\begin{array}{llllllll}(1) & (2) & (3) & (4) & (5) & (6) & \text { (7) } & \text { (8) }\end{array}$

Panel A. Dependent variable: Total factor productivity

\begin{tabular}{|c|c|c|c|c|c|c|c|c|c|}
\hline \multirow[b]{2}{*}{ Year } & \multicolumn{3}{|c|}{ Before (pre-policy) } & \multicolumn{3}{|c|}{ After (post-policy) } & \multirow{2}{*}{$\begin{array}{l}\text { Before } \\
\begin{array}{c}2006-08 \\
\text { average }\end{array}\end{array}$} & \multirow{2}{*}{$\begin{array}{c}\text { After } \\
2009-11 \\
\text { average }\end{array}$} & \multirow{2}{*}{$\begin{array}{c}\text { Difference } \\
\text { After - Before }\end{array}$} \\
\hline & 2006 & 2007 & 2008 & 2009 & 2010 & 2011 & & & \\
\hline \multirow{2}{*}{$\begin{array}{l}\text { Below asset threshold } \\
\text { dummy (in 2007) }\end{array}$} & -0.163 & 0.054 & 0.083 & 0.281 & $0.452 * *$ & 0.254 & 0.037 & 0.278 & $0.241 * *$ \\
\hline & $(0.191)$ & $(0.173)$ & $(0.165)$ & $(0.174)$ & $(0.192)$ & $(0.202)$ & $(0.165)$ & $(0.175)$ & $(0.122)$ \\
\hline Firms & 1,634 & 1,673 & 1,583 & 1,578 & 1,683 & 1,654 & 1,598 & 1,598 & 1,598 \\
\hline \multicolumn{10}{|c|}{ Panel B. Dependent variable: Ln(Sales) } \\
\hline \multirow{2}{*}{$\begin{array}{l}\text { Below asset threshold } \\
\text { dummy (in 2007) }\end{array}$} & -0.187 & 0.029 & -0.102 & 0.212 & $0.404 * *$ & 0.297 & -0.012 & 0.231 & $0.218^{*}$ \\
\hline & $(0.170)$ & $(0.167)$ & $(0.162)$ & $(0.180)$ & $(0.187)$ & $(0.192)$ & $(0.154)$ & $(0.177)$ & $(0.114)$ \\
\hline Firms & 3,292 & 3,439 & 3,393 & 3,311 & 3,294 & 3,255 & 3,398 & 3,398 & 3,398 \\
\hline \multicolumn{10}{|c|}{$\begin{array}{l}\text { Panel C. Dependent variable: Ln(Employment) } \\
\end{array}$} \\
\hline \multirow{2}{*}{$\begin{array}{l}\text { Below asset threshold } \\
\text { dummy (in 2007) }\end{array}$} & -0.0118 & 0.102 & 0.0838 & 0.107 & $0.263^{*}$ & $0.292 *$ & 0.055 & 0.188 & 0.134 \\
\hline & $(0.126)$ & $(0.123)$ & $(0.131)$ & $(0.140)$ & $(0.147)$ & $(0.153)$ & $(0.125)$ & $(0.141)$ & $(0.086)$ \\
\hline Firms & 2,468 & 2,550 & 2,431 & 2,445 & 2,551 & 2,469 & 2,387 & 2,387 & 2,387 \\
\hline \multicolumn{10}{|c|}{$\begin{array}{l}\text { Panel D. Dependent variable: Ln(Capital) } \\
\end{array}$} \\
\hline \multirow{2}{*}{$\begin{array}{l}\text { Below asset threshold } \\
\text { dummy (in 2007) }\end{array}$} & -0.017 & -0.035 & -0.0096 & -0.020 & -0.008 & 0.010 & -0.077 & -0.038 & 0.039 \\
\hline & $(0.120)$ & $(0.109)$ & $(0.113)$ & $(0.122)$ & $(0.131)$ & $(0.135)$ & $(0.106)$ & $(0.124)$ & $(0.077)$ \\
\hline Firms & 3,721 & 3,958 & 3,791 & 3,608 & 3,451 & 3,316 & 3,651 & 3,651 & 3,651 \\
\hline
\end{tabular}

Note: *** significant at $1 \%$ level, $* * 5 \%$ level, $* 10 \%$ level. Regression Discontinuity Design (RDD) results (OLS). The running variable is total assets in 2007 with a threshold of $€ 86 \mathrm{~m}$. Baseline sample includes firms with total assets in 2007 within $€ 25 \mathrm{~m}$ below and above the cut-off (i.e. between $€ 61 \mathrm{~m}$ and $€ 111 \mathrm{~m}$ ). Controls for the running variable separately for each side of the threshold and two digit industry dummies are included. Robust standard errors are in brackets. Total factor productivity in Panel A is calculated as $\ln$ (value added $)-\propto_{k} \ln ($ capital $)-\propto_{l} \ln ($ employment $)$, where value added is imputed as sales minus materials and $\propto_{k}$ and $\propto_{l}$ are estimated using Olley-Pakes production function estimation separately for each two-digit industry across all firms in the FAME dataset across the 2000-2005 period. Panel B uses sales from CT600. Panel C uses employment (from FAME). Panel D uses fixed assets (from FAME). Columns (7) - (9) condition on the "balanced" sample where we observe the outcome variable in at least one year of the pre-policy sample and one year of the post-policy sample (i.e. it is a sub-sample of the observations in columns (1) - (6)). 
Table 9: Estimating R\&D technology spillovers

\begin{tabular}{|c|c|c|c|c|c|c|}
\hline \multirow{3}{*}{$\begin{array}{l}\text { Specification } \\
\text { Dependent variable: } \\
\text { (2009-2011 average) }\end{array}$} & $(1)$ & $(2)$ & \multirow{3}{*}{$\begin{array}{c}(3) \\
\begin{array}{c}\text { Reduced form, } \\
\text { OLS }\end{array} \\
\begin{array}{c}\text { All patent } \\
\text { count }\end{array}\end{array}$} & $(4)$ & $(5)$ & (6) \\
\hline & \multicolumn{2}{|c|}{ First stage, OLS } & & \multicolumn{3}{|c|}{ IV } \\
\hline & spilltechRD & $\begin{array}{l}\text { R\&D exp. } \\
\text { (£ million) }\end{array}$ & & $\begin{array}{l}\text { R\&D exp. } \\
\text { ( } £ \text { million) }\end{array}$ & $\begin{array}{c}\text { All patent } \\
\text { count }\end{array}$ & $\begin{array}{c}\text { All patent } \\
\text { count }\end{array}$ \\
\hline spilltechSME (sum tech. distance $x$ dummy) & $\begin{array}{c}11.18 * * * \\
(2.16)\end{array}$ & $\begin{array}{c}0.011 \\
(0.093)\end{array}$ & $\begin{array}{l}0.183 * * \\
(0.079)\end{array}$ & & & \\
\hline Below asset threshold dummy (in 2007) & $\begin{array}{c}0.40 \\
(1.36)\end{array}$ & $\begin{array}{c}0.159 * * \\
(0.064)\end{array}$ & $\begin{array}{c}0.073 * * \\
(0.030)\end{array}$ & $\begin{array}{c}0.159 * * \\
(0.064)\end{array}$ & $\begin{array}{l}0.066 * \\
(0.040)\end{array}$ & \\
\hline spilltechRD (sum tech. distance $x £$ million) & & & & $\begin{array}{c}0.001 \\
(0.009)\end{array}$ & $\begin{array}{c}0.016 * * \\
(0.008)\end{array}$ & $\begin{array}{c}0.016 \\
(0.011)\end{array}$ \\
\hline R\&D expenditure ( $£$ million), 2009-11 average & & & & & & $\begin{array}{c}0.416 \\
(1.666)\end{array}$ \\
\hline Mean of dependent variable (2006-08) & 25.02 & 0.068 & 0.057 & 0.068 & 0.057 & 0.057 \\
\hline Firms & 8,818 & 8,818 & 8,818 & 8,818 & 8,818 & 8,818 \\
\hline
\end{tabular}

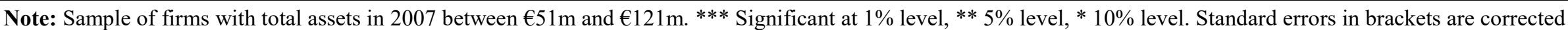

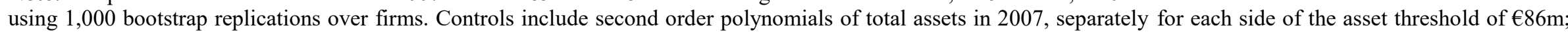

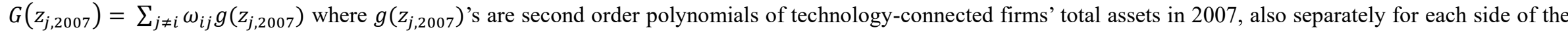

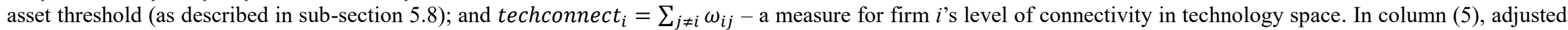

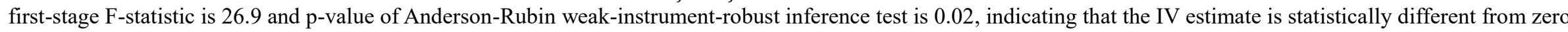

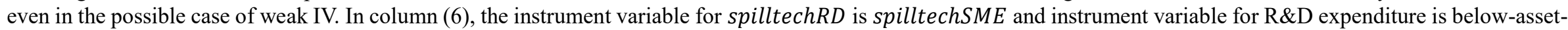
threshold dummy. 


\section{APPENDICES: FOR ONLINE PUBLICATION ONLY}

\section{Appendix A: Institutional details of policy and tax-adjusted user cost}

\section{A.1 SME definition}

The UK Tax Relief Scheme's SME (Small and Medium Sized Enterprise) definition is set according to the European Commission's Recommendations 1996/280/EC (effective up to December $31^{\text {st }} 2004$ ) and 2003/361/EC (effective from January $1^{\text {st }} 2005$ ). The definition is based on assets ("balance sheet total"), employment ("staff headcount") and sales ("turnover") as described in Section 2. There are also some restrictions on the type of eligible enterprises. Below is a summary of the SME definition according to Recommendations 2003/361/EC. For further technical details on many parts of the tax rules see http://www.hmrc.gov.uk/manuals/cirdmanual/CIRD91400.htm.

Measurements of staff headcount, assets, and sales turnover for ceiling tests: Assets is the gross amount of assets shown in the accounts. The staff headcount of an enterprise represents the number of full-time person-years attributable to people who have worked within or for the enterprise during the year under consideration. ${ }^{1}$ The staff headcount and financial data used for the "ceiling tests" (the maximum values possible for a firm to be eligible for SME status) are those relating to the latest approved accounting period, calculated on an annual basis and aggregated according to the rules described below. Assets and sales figures are converted to Euros using the exchange rate on the last day of the relevant accounting period, or the average exchange rate throughout that accounting period (whichever is more beneficial for the enterprise). An enterprise passes the ceiling tests if its staff headcount and either its aggregated assets or its aggregated turnover fall below the respective ceilings. An enterprise loses (acquires) its SME status if it fails (passes) the ceiling tests over two consecutive accounting periods.

Account aggregation rules for different enterprise types: In the case of an autonomous enterprise, the staff headcount and financial data are determined exclusively on the basis of the accounts of the enterprise (or the consolidated accounts) of the enterprise itself. ${ }^{2}$ In the case of a "linked" enterprise, the ceiling tests are applied to the aggregates of the figures in its own accounts and those from the accounts of all other enterprises to which it is linked (including non-UK ones), unless the linked enterprises' account data are already included through account consolidation. ${ }^{3}$ For further details of the European Commission's recommendations for SME definition, see Recommendation 1996/280/EC and

\footnotetext{
${ }^{1}$ The contributions of part-time workers, or those who work on a seasonal or temporary basis count as appropriate fractions of a full-time person-year. The term staff includes employees, persons seconded to the enterprise, ownermanagers, partners (other than sleeping partners); it excludes apprentices or students engaged in vocational training with an apprenticeship or vocational training contract, and any periods or maternity or parental leave.

${ }^{2}$ An autonomous enterprise is defined by exclusion: one that is not a linked enterprise or a partner enterprise. Generally, an enterprise is autonomous if it has holding of less than $25 \%$ of the capital or voting rights in one or more enterprises and/or other enterprises do not have a stake of $25 \%$ or more of the capital voting rights in the enterprise.

${ }^{3}$ Linked enterprises are those in which one enterprise is able to exercise control, directly or indirectly, over the affairs of the other.
} 
Recommendation 2003/361/EC.

\section{A.2 UK R\&D Tax Relief Scheme}

The UK R\&D Tax Relief Scheme includes a SME Scheme and a Large Company ("LCO”) Scheme. ${ }^{4}$ Since its introduction in 2000 up until 2012, more than 28,500 different companies had made claims under the SME Scheme, and over 7,000 under the Large Company Scheme, claiming more than $£ 9.5 \mathrm{bn}$ in total R\&D support. The annual amount of R\&D support had risen to over $£ 1$ bn by 2008 , reaching $£ 1.4 \mathrm{bn}$ in 2012, and covered qualifying R\&D expenditure worth $£ 13.2 \mathrm{bn}$ (HMRC, 2014).

Both SME and Large Company Schemes are volume-based, i.e. the tax relief accrues on the total $R \& D$ spending rather than the incremental R\&D over a prior base (the main US tax credit scheme is incremental). It works mostly through enhanced deduction of current R\&D expenditure from taxable income, thus reducing R\&D-performing companies' corporate tax liabilities. ${ }^{5}$ In addition, under the SME Scheme, a company that has taxable loss after the additional deduction can also claim payable tax credit up to the amount of payable credit rate $\times$ enhanced qualifying $R \& D$ expenditure. ${ }^{6}$ This payable tax credit can only be used to reduce the company's PAYE (Pay-As-You-Earn) or NIC (National Insurance Contributions) liabilities. Alternatively, the company (either as an SME or as a large company) can choose to carry the loss forward as normal. ${ }^{7}$

Qualifying R\&D expenditure must be allowable as a deduction in calculating trading profits, which includes all flow costs, employee costs, staff providers, materials, payments to clinical trials volunteers, utilities, software, or subcontracted R\&D expenditure (only if the contractor is an SME). ${ }^{8}$ To be eligible for R\&D tax relief, a company must also spend at least $£ 10,000$ a year on qualifying $R \& D$ expenditure in an accounting period. If an SME works as a subcontractor for a large company, only the subcontractor SME can claim R\&D tax relief, under the Large Company Scheme. ${ }^{9}$ There is also an upper limit of $€ 7.5 \mathrm{~m}$

\footnotetext{
4 For further details, see http://www.hmrc.gov.uk/manuals/cirdmanual/CIRD90000.htm (SME Scheme) and http://www.hmrc.gov.uk/manuals/cirdmanual/CIRD85050.htm (Large Company Scheme).

${ }^{5}$ For example, if a company is allowed an enhancement rate of $75 \%$, for each $£ 100$ of qualifying R\&D expenditure it spends, it can deduct an additional $£ 75$ from its taxable income before calculating its tax liability.

${ }^{6}$ For example, if a company is allowed an enhancement rate of $75 \%$ and payable credit rate of $14 \%$, spends $£ 10,000$ in $\mathrm{R} \& \mathrm{D}$, and has no taxable income before the additional deduction, it can claim payable tax credit of $0.14 \times$ $£ 10,000 \times(1+0.75)=£ 2,450$. If instead the company has $£ 1,500$ in taxable income before the additional deduction, it can first use $£ 2,000$ of its $R \& D$ to reduce its taxable income to zero (i.e. $£ 1,500=75 \% \times £ 2000$, then claim payable tax credit of $0.14 \times £ 8,000 \times(1+0.75)=£ 1,960$. This latter case is called a combination claim. ${ }^{7}$ A large company that has taxable loss before the additional deduction therefore may still benefit from R\&D tax relief by carrying the "enhanced" loss forward to further reduce its taxable income in the next period. However, this reduction is only meaningful when the company has enough taxable income in this next period.

${ }^{8}$ Qualifying R\&D expenditure could include R\&D performed outside of the UK by foreign branches of UK holding companies, as foreign branches' revenues and costs are directly consolidated into their UK holding companies' tax revenues and costs for UK tax purpose. Qualifying R\&D expenditure is unlikely to include R\&D performed outside of the UK by foreign subsidiaries of UK holding companies, as foreign subsidiaries' net profits are indirectly incorporated into their UK holding companies' tax revenues as dividends for UK tax purpose instead.

${ }^{9}$ An SME already receiving another form of notified state aid for a project cannot claim R\&D tax relief for that same project under the SME Scheme (which is also a notified state aid), as total state aid intensity cannot exceed 25\% under European Commission's State Aid rules. However, from April 2003 onward, SMEs were allowed to claim R\&D tax relief for such projects under the Large Company Scheme.
} 
on the total amount of aid a company can receive for any one R\&D project under the SME Scheme. ${ }^{10}$

The evolution of the UK R\&D Tax Relief Scheme is summarized in Table A1. It was first introduced in April 2000 only for SMEs (Finance Act 2000), then later extended to large companies starting from April 2002 (Finance Act 2002). ${ }^{11}$ Between April 2000 and December 2004, the UK followed Recommendation 1996/280/EC for SME definition, which set the ceilings for staff headcount, assets, and sales at $249, € 27 \mathrm{~m}$, and $€ 40 \mathrm{~m}$ respectively. From January 2005 , the UK adopted Recommendation $2003 / 361 / E C$ and accordingly increased its SME ceilings to $249, € 43 \mathrm{~m}$, and $€ 50 \mathrm{~m}$. Throughout the period from April 2000 (April 2002) to March 2008, the enhancement rates were set at 50\% for SMEs and 25\% for large companies, and the payable credit rate for SMEs was $16 \%{ }^{12}$

As discussed in the main paper, numerous changes to the scheme, in both SME eligibility thresholds and relief rates, became effective at different points in 2008. ${ }^{13}$ First, from April 2008, the enhancement rate for large companies was increased from 25\% to 30\%. Then from August 2008, the enhancement rate for SMEs was increased from $50 \%$ to $75 \%$ and the payable credit rate for SMEs was reduced from $16 \%$ to $14 \%$ (to ensure that state aid intensity stays below the EU imposed limit of $25 \%$ ). Also from August 2008 , the SME Scheme was extended to "larger" SMEs as the SME ceilings were doubled to 499, $€ 86 \mathrm{~m}$, and $€ 100 \mathrm{~m}$ for staff headcount, assets, and sales respectively. This change in SME definition is applicable only for the purpose of the R\&D tax relief and therefore is the main focus of our paper, as it allows us to separate the impacts of the R\&D Tax Relief Scheme from other programs. It should also be noted that even though these new SME ceilings were announced in Finance Act 2007, the date on which they became effective (August $1^{\text {st }}$ 2008) was appointed much later, in July 2008. ${ }^{14}$

There were tweaks to the system in 2011 and 2012. From April 2011, the SME enhancement rate was increased to $100 \%$ and the SME payable credit rate was reduced to $12.5 \%$. From April 2012, the SME enhancement rate was again increased to $125 \%$. However, the SME definition as announced in Finance Act 2007 and the large company enhancement rate of 30\% remained unchanged throughout this period.

\section{A.3 Model of $R \& D$ demand}

Consider a CES production function in R\&D capital $(G)$ and non-R\&D capital $(Z)$. If input markets are competitive we can write the long-run static first order condition for relative factor demand

\footnotetext{
${ }^{10}$ In practice, most companies prefer R\&D Tax Relief's SME Scheme over other notified state aids, as the scheme is sufficiently generous (the maximum relief intensity under the SME Scheme is close to 25\%) and is straightforward to apply for. For further details on other conditions, see http://www.hmrc.gov.uk/manuals/cirdmanual/CIRD81000.htm.

${ }^{11}$ Finance Act 2000 (Chapter 17, Schedule 20) and Finance Act 2002 (Chapter 23, Schedule 12).

12 One exception to this differential treatment of SMEs and large companies was the Vaccine Research Relief Scheme (VRR) launched in April 2003, which extended the higher 50\% additional allowance to cover specific areas of vaccine and drug research conducted in large companies (Finance Act 2003, Chapter 14, Schedule 31). The VRR enhancement rate was later reduced to $40 \%$ from August 2008 onward.

${ }^{13}$ Finance Act 2007 (Chapter 11).

${ }^{14}$ Finance Act 2007, Section 50 (Appointed Day) Order 2008 of July $16^{\text {th }} 2008$.
} 
of the firm as:

$$
\ln G=-\sigma \ln \rho+\sigma \ln U+\ln Z+B
$$

where $\rho$ is the user cost of R\&D capital, $U$ is is the user cost of non-R\&D capital and $B$ is a technological constants representing factor bias terms in the production function. Assume that $G$ can be described by the perpetual inventory formula $G_{t}=(1-\delta) G_{t-1}+r d_{t}$ where $r d_{t}$ is the R\&D expenditure in period $t$. Since in steady state, the R\&D just offsets the depreciated part of the R\&D stock $\delta G=r d$, we can rewrite the first order condition in steady state as:

$$
\ln r d=-\sigma \ln \rho+\sigma \ln U+\ln Z+\ln \delta+\mathrm{B}
$$

This is essentially the equation we estimate in equation (1). Around the R\&D SME threshold the user cost of non-R\&D capital and technology are smooth. Non-R\&D capital (assets) is the running variable so we have a polynomial approximation to $\ln Z$. The only departure from this first-order condition is that we cannot estimate $R \& D$ in logarithms because of the presence of firms who do not do any R\&D, so we estimate the left hand side in levels instead of logs. To obtain the proportionate change in R\&D we use the empirical averages of lagged R\&D spending in the pre-policy change period (or explicitly condition on the firm's lagged R\&D). We also show that the calculations are robust to using a Poisson regression whose first moment is the exponential log-link function and so is equivalent to estimating in logarithms.

\section{A.4 Tax-adjusted user cost of $R \& D$}

The full formula for tax-adjusted user cost of R\&D as described in sub-section 5.2 is:

$\rho_{t, f}=\left(\operatorname{Pr}(\right.$ Has tax liability $) \times \frac{\left(1-\tau_{t}\left(1+e_{t, f}\right)\right)}{\left(1-\tau_{t}\right)}+\operatorname{Pr}($ No tax liability $\left.) \times\left(1-c_{t, f}\left(1+e_{t, f}\right)\right)\right) \times(r+\delta)$

where $\tau$ is the effective corporate tax rate, $e$ is the enhancement rate, $c$ is the payable credit rate, $r$ is the real interest rate, $\delta$ is the depreciation rate, $t$ denotes year, and $f$ denotes the whether the company is an SME or a large company. Note that $\rho_{t, f}$ varies over time with $\tau_{t}, e_{t, f}$, and $c_{t, f}$.

For simplicity, we do not consider the possibility that a loss-making large company may still benefit from R\&D tax relief by carrying the "enhanced" loss forward to reduce its taxable income in the next period, as this reduction is only meaningful if the company makes enough profits in this next period. This simplification may overestimate large companies' tax-adjusted user cost of R\&D and, as a result, underestimate $R \& D$ tax-price elasticity (by overestimating the difference in tax-adjusted user cost of R\&D between SMEs and large companies). We also do not consider combination claims (cases in which an SME combines tax deduction with the payable tax credit as there are almost none of them in our baseline sample.

The evolution of tax adjusted user costs of R\&D for SMEs and large companies over time is summarized in Table A11. For large companies (for which the payable credit rate is always zero), there are slight decreases in the corporate tax rate over 2006-12 (from 30\% to $28 \%$ to $26 \%$ ) coupled with slight 
increases in the enhancement rate (from $25 \%$ to $30 \%$ ) over the same period. This resulted in a relatively stable tax-adjusted user cost of 0.190 throughout this period. It is therefore reasonable to use the baseline sample's average R\&D over 2006-08 as a proxy for how much an average firm in the baseline sample would spend on R\&D if it remained a large company over 2009-11, after the policy change. For SMEs, large increases in enhancement rate (from $50 \%$ to $75 \%$ to $100 \%$ ) more than offset the slight decrease in corporate tax rate and payable credit rate (from $16 \%$ to $14 \%$ to $12.5 \%$ ), leading to a steady reduction in SMEs' tax-adjusted user cost of R\&D from 0.154 in 2006 to 0.141 in 2011. This widens the difference in tax-adjusted user cost of R\&D between SMEs and large companies over time, from an average log difference of -0.219 over 2006-08 to an average log difference of -0.271 over 2009-11.

Finally, as a robustness check, we also consider using the small profit rate (from $19 \%$ to $21 \%$ to $20 \%$ over 2006-11) instead of the main rate for corporate tax rate. As the tax deduction is less generous with a lower corporate tax rate, the resulting tax-adjusted user cost in the tax deduction case is higher for both SMEs and large companies and their gap is smaller in magnitude (average log difference over 2006-08 is -0.185 and over $2009-11$ is -0.229 ).

\section{A.5 Cost effectiveness analysis of R\&D Tax Relief Scheme}

A full welfare analysis of the R\&D Tax Relief Scheme requires both an analysis of the benefits in terms of (say) the increased GDP generated by the R\&D induced by the policy (including spillovers) and the deadweight cost of taxation. We would also need to take a position on other general equilibrium effects such as the increase in the wages of R\&D workers due to increased demand (Goolsbee, 1998). As an interim step towards this we follow the convention in the literature which is to calculating a "value for money" ratio $\frac{\Delta_{R D}}{\Delta_{E C}}$ where $\Delta_{R D}$ is the amount of R\&D induced by the policy and $\Delta_{E C}$ is the total amount of additional taxpayer money needed to pay for the scheme (which we call "Exchequer Cost", EC).

\section{A.5.12008 extension of the SME Scheme}

With respect to the 2008 extension of the SME Scheme to cover "larger" SMEs, $\Delta_{R D}$ measures the increase in R\&D induced by more generous tax relief under the SME scheme by a firm benefitting from the scheme thanks to the new thresholds. That is, $\Delta_{R D}=R D_{\text {new }}-R D_{\text {old }}$ where $R D_{\text {new }}$ and $R D_{\text {old }}$ are the firm's R\&D's under the new and old policies respectively. Similarly, $\Delta_{E C}=E C_{\text {new }}-E C_{\text {old }}$ where $E C_{\text {new }}$ and $E C_{\text {old }}$ are the firm's corresponding Exchequer costs due to the policy change.

Rearranging the R\&D tax-price elasticity formula $\eta=\frac{\ln \left(R D_{\text {new }} / R D_{\text {old }}\right)}{\ln \left(\rho_{\text {new }} / \rho_{\text {old }}\right)}$ gives

$$
\ln \left(\frac{R D_{\text {new }}}{R D_{\text {old }}}\right)=\eta \times \ln \left(\frac{\rho_{\text {new }}}{\rho_{\text {old }}}\right)
$$

where $\rho$ is the tax-adjusted user cost of R\&D. For simplicity, we consider the tax deduction case and the payable tax credit case separately.

\section{$\underline{\text { SME Tax deduction case }}$}


In this case,

$$
\begin{gathered}
\rho^{\text {deduction }}=\frac{(1-\tau(1+e))}{1-\tau}(r+\delta) \\
E C^{\text {deduction }}=R D \times e \times \tau
\end{gathered}
$$

where $\tau$ is the effective corporate tax rate, $e$ is the enhancement rate, $r$ is the real interest rate, and $\delta$ is the depreciation rate. As the above firm moves from being a large company pre-2008 to being an SME post-2008, its enhancement rate increases from $25 \%$ to $75 \%$. At the same time, corporate tax rate decreases from $30 \%$ to $28 \%$. Combining $e_{\text {old }}=0.25, e_{\text {new }}=0.75, \tau_{\text {old }}=0.30, \tau_{\text {new }}=0.28$ with estimated R\&D tax-price elasticity of $\eta=-2.63$ gives $\ln \left(\frac{\rho_{\text {new }}}{\rho_{\text {old }}}\right)=-0.23$ and $\frac{R D_{\text {new }}}{R D_{\text {old }}}=1.84$. That is, R\&D increases by $84 \%$ in response to a $23 \%$ reduction in its user cost.

On the cost side, we have

$$
\begin{gathered}
E C_{\text {old }}=R D_{\text {old }} \times e_{\text {old }} \times \tau_{\text {old }}=R D_{\text {old }} \times 0.075 \\
E C_{\text {new }}=R D_{\text {new }} \times e_{\text {new }} \times \tau_{\text {new }}=R D_{\text {new }} \times 0.21 .
\end{gathered}
$$

Putting all the elements together gives

$$
\frac{\Delta_{R D}}{\Delta_{E C}}=\frac{R D_{\text {new }}-R D_{\text {old }}}{E C_{\text {new }}-E C_{\text {old }}}=\frac{\left(R D_{\text {old }} \times 1.84\right)-R D_{\text {old }}}{\left(R D_{\text {old }} \times 1.84 \times 0.21\right)-\left(R D_{\text {old }} \times 0.075\right)}=\frac{0.84}{0.31}=2.70 .
$$

so the value for money ratio in the tax deduction case is 2.70 . In other words, $£ 1$ of taxpayer money generates $£ 2.70$ in additional R\&D.

Finally, note that $\Delta_{E C}$ could be rewritten as

$$
\Delta_{E C}=E C_{\text {new }}-E C_{\text {old }}=R D_{\text {new }} \times 0.21-R D_{\text {old }} \times 0.075=\Delta_{R D} \times 0.21+R D_{\text {old }} \times(0.21-0.075)
$$

where the first element represents the Exchequer costs associated with new $R \& D$ and the second term reflects additional Exchequer costs paid on existing R\&D due to more generous tax relief. In this case, the majority of the additional costs are because of the new R\&D generated, i.e. $\Delta_{R D} \times 0.21=R D_{\text {old }} \times$ 0.18 makes up close to $60 \%$ of $\Delta_{E C}\left(\Delta_{E C}=R D_{\text {old }} \times 0.31\right)$.

\section{SME Payable tax credit case}

In this case,

$$
\begin{gathered}
\rho^{\text {credit }}=(1-c(1+e))(r+\delta) \\
E C^{\text {credit }}=R D \times c \times(1+e)
\end{gathered}
$$

where $c$ - the payable credit rate - is always zero for large companies and 14\% for SMEs post-2008. Combining $c_{\text {old }}=0, c_{\text {new }}=0.14, e_{\text {old }}=0.25, e_{\text {new }}=0.75$, and $\eta=-2.63$ gives $\ln \frac{\rho_{\text {new }}}{\rho_{\text {old }}}=-0.28$ and $\frac{R D_{\text {new }}}{R D_{\text {old }}}=2.09$ (i.e. $\mathrm{R} \& \mathrm{D}$ increases by $109 \%$ in response to a $28 \%$ reduction in its log user cost). On the cost side, $E C_{\text {old }}=0$ and $E C_{\text {new }}=R D_{\text {new }} \times c_{\text {new }} \times\left(1+e_{\text {new }}\right)=R D_{\text {new }} \times 0.25$. Putting all the elements together gives

$$
\frac{\Delta_{R D}}{\Delta_{E C}}=\frac{R D_{\text {new }}-R D_{\text {old }}}{E C_{\text {new }}-E C_{\text {old }}}=\frac{R D_{\text {old }} \times 2.09-R D_{\text {old }}}{R D_{\text {old }} \times 2.09 \times 0.25-0}=\frac{1.09}{0.51}=2.13 .
$$


The value for money ratio in the payable tax credit case is 2.13 . In this case, the amount of additional R\&D's Exchequer costs due to newly-generated $\mathrm{R} \& \mathrm{D} \Delta_{R D} \times 0.25=R D_{\text {old }} \times 0.27$ constitutes more than $50 \%$ of $\Delta_{E C}\left(\Delta_{E C}=R D_{\text {old }} \times 0.51\right)$.

\section{A.5.2 R\&D Tax Relief Scheme over 2006-11}

To evaluate the overall R\&D Tax Relief Scheme over 2006-11, we calculate

$$
\frac{\Delta_{R D}}{\Delta_{E C}}=\frac{R D_{\text {tax relief }}-R D_{\text {no tax relief }}}{E C_{\text {tax relief }}-E C_{\text {no tax relief }}}=\frac{R D_{\text {taxrelief }}-R D_{\text {no tax relief }}}{E C}
$$

separately for each of three cases, SME tax deduction case (Table A13, Panel B), SME payable tax credit case (Panel C), and large company tax deduction case (Panel D), in each of the years using the same approach as described in detail above. We generalize our estimated tax-price elasticity of 2.6 to the whole population of SMEs, but use a more conservative tax-price elasticity of 1.0 for the population of large companies as these firms are less likely to be credit constrained and therefore less responsive to tax incentives. In addition, we use the small profits rate (19\%-21\%) instead of the regular corporate tax rate (26\%-30\%) for the population of SMEs as most of them are much smaller than the "larger" SMEs in our baseline sample and therefore most likely qualify for the small profits rate.

As reported in Table A13, the SME tax deduction's value for money ratio decreases from 2.9 in 2006 to 2.7 in 2011 as SME tax deduction becomes significantly more generous over time. On the other hand, SME payable tax credits and large company tax deduction's value for money ratios are stable at around 2.1 and 1.4 respectively as these schemes do not change much over this period. The fact that all the value for money ratios are well above unity indicates that the R\&D Tax Relief Scheme is effective in inducing additional $R \& D$ at relatively low cost to the Exchequer.

Finally, we estimate the amount of additional R\&D induced by the R\&D Tax Relief Scheme as $\Delta_{R D}=\frac{\Delta_{R D}}{\Delta_{E C}} \times E C$ using the calculated value for money ratios $\frac{\Delta_{R D}}{\Delta_{E C}}$ and Exchequer costs national statistics (HMRC 2015). We do this for each of the three schemes in Panels B, C and D and then aggregate them together in Panel D.

To give an example, consider the SME tax deduction case in Panel B for 2009. The user cost is calculated using the policy parameters given, i.e. $\frac{1-0.21 \times(1+0.75)}{1-0.21}(0.05+0.15)=0.160$. This compares to a user cost of $0.20=0.05+0.15$ in the counterfactual world without any tax relief $(e=0)$. The log difference in user cost is -0.222 . Applying the formula we obtain:

$$
\left(\frac{\Delta_{R D}}{\Delta_{E C}}\right)^{\text {deduction }}=\frac{1}{e \tau}\left(1-\frac{1}{\exp \left(\eta \times \ln \left(\frac{\rho_{\text {new }}}{\rho_{\text {old }}}\right)\right)}\right)
$$

or $\left(\frac{1}{0.75 \times 0.21}\right)\left(1-\frac{1}{\exp (2.63 \times 0.2223)}\right)=2.811$ as in the second row of Table A13 Panel B. From HMRC data we know that $£ 130 \mathrm{~m}$ was paid out in the SME deduction in this year. Hence, we can calculate that the total amount of additional R\&D induced was $£ 365 m=130 \times 2.811$ (fourth row of Panel B). 
As discussed in sub-section 5.4, our estimates suggest that the overall impact of the R\&D Tax Relief Scheme is large in Panel E. Over 2006-11, the policy, which costs less than $£ 6$ billion in lost tax revenue, induced close to $£ 10$ billion in additional R\&D. On an annualized basis, spending $£ 0.96 b$ produced $£ 1.64 b$ of additional $R \& D$.

These calculations show our estimates of what the counterfactual path of $R \& D$ would have been in the absence of the R\&D Tax Relief Scheme. The bottom row of Table A13 gives the yearly breakdown. For example, the final column shows that on average 2006-11 we estimate that R\&D would be a full 16\% lower in the absence of the tax scheme.

It is important to note that throughout our analysis we have been focusing on qualifying R\&D, i.e. that part of business $R \& D$ that is eligible for tax relief. Aggregate qualifying $R \& D$ is lower than the figures for Business Enterprise R\&D (BERD) reported in Figure 4. For example, in 2011 aggregate BERD was $£ 17 \mathrm{bn}$ and aggregate qualifying $R \& D$ was $£ 12 \mathrm{bn}$. There are various reasons for this difference, including the fact that BERD includes R\&D spending on capital investment whereas qualified R\&D does not (only current expenses are liable). It is also the case that HMRC defines R\&D more narrowly for tax purposes that BERD which is based on Frascati definition.

We present counterfactual BERD to GDP ratios in Figure 4. To calculate the counterfactual (the dotted line "UK without tax relied" in Figure 4) we simply deduct the additional qualified R\&D that we estimate were created by the R\&D tax relief system (Table A13, Panel D "Total Additional R\&D") from the aggregate BERD numbers from OECD MSTI Dataset (https://stats.oecd.org/Index.aspx?DataSetCode=MSTI_PUB). Since BERD is greater than qualifying $R \& D$, the $16 \%$ fall in qualifying $R \& D$ translates to about a $10 \%$ fall in BERD. 


\section{Appendix B: Data}

\section{B.1 CT600 dataset}

The CT600 dataset is constructed by the UK tax authority (HMRC) and is a confidential panel dataset of corporate tax returns or assessments made from the returns for the universe of companies that file a corporate tax return in the UK. We can only access the dataset from within an HMRC facility (similar to a US Census Bureau Research Data Center) and merging with other datasets requires approval from HMRC. It is currently not possible to merge CT600 with other government secured datasets available at different facilities. ${ }^{15}$ The CT600 dataset covers all accounting periods whose end dates fall between April $1^{\text {st }} 2001$ and March $31^{\text {st }} 2012$ and consists of all information on the UK Company Tax Return form (which is called the CT600 form). Specifically, an extension of CT600, the Research and Development Tax Credits (RDTC) dataset, provides detailed information on tax relief claims. However, CT600 contains little information on financial statement variables (e.g. assets and employment are not included) as they are not directly required on corporate tax forms.

We convert the original observation unit of firm by accounting period in CT600 to firm by financial year by aggregating all accounting periods the end dates of which fall in the same financial year. ${ }^{16}$ This conversion affects a very small number of observations as only $3 \%$ of our firm by year observations are aggregates of multiple accounting periods. Our converted dataset then contains 15.7 million firm by year observations over 12 financial years from 2000 to 2011 (covering 3.2 million firms), including 9.1 million firm by year observations over our study period from 2006 to 2011 (covering 2.5 million firms).

Our key variables of interest are those related to firms' R\&D tax relief claims from CT600's RDTC dataset, which include the amount of qualifying $R \& D$ expenditure each firm has in each year and the scheme under which it makes the claim (SME vs. Large Company Scheme). These variables, originally self-reported by firms on their CT600 forms, have been further validated and corrected by HMRC staff using additional tax processing data available only within the tax authority. It should also be noted that $R \& D$ tax relief variables are only available for R\&D-tax-relief-claiming firms for the years in which they make the claims. While it is possible to infer that non-claiming firms have zero qualifying $\mathrm{R} \& \mathrm{D}$ expenditure, it is not possible to construct their precise SME eligibility without full information on employment, assets (balance sheet total), sales, and ownership structure.

Table B1 shows that over our study period between 2006 and 2011, we observe claims in 53,491 firm by year observations (by 20,730 firms), $81 \%$ of which are under the SME Scheme. The total qualifying R\&D expenditure and estimated Exchequer costs under the SME Scheme are in nominal terms $£ 11.2 \mathrm{bn}$ and $£ 1.8 \mathrm{bn}$ respectively; the corresponding figures under the Large Company Scheme are $£ 48.5$ bn and $£ 3.9$ bn (excluding claims by SME subcontractors). These figures are in line with the official

\footnotetext{
${ }^{15}$ For example, it is currently not possible to merge CT600 with the BERD firm survey which is used to build the national estimate of R\&D.

${ }^{16}$ Financial year $t$ begins on April $1^{\text {st }}$ of year $t$ and ends on March $31^{\text {st }}$ of year $t+1$. So the last year that is currently available to use is 2011 .
} 
R\&D Tax Relief Scheme statistics released in HMRC (2014).

We also use the data on sales and on investment in plant and machinery from CT600. Sales are reported for $93 \%$ of firm by year observations and annualized to account for different accounting period lengths. CT600 tax-accounting sales, which is calculated using the cash-based method, is not the same as financial-accounting sales (reported in the FAME data - see below), which is calculated using the accrual method and used to determine SME eligibility. ${ }^{17}$ However, CT600 sales provides a good measure for firms' growth and performance, given its relatively wide coverage.

\section{B. 2 FAME dataset}

FAME is a database of UK companies provided by Bureau Van Dijk. The panel dataset contains companies' balance sheet and income statement data from companies' annual accounts filed at the UK company registry (Companies House), together with additional information on addresses and industry codes. Like other countries, UK regulations for reporting accounting variables vary with company size, so some balance sheet and income statement variables are missing - we discuss the implications of this below. ${ }^{18}$

Our FAME dataset also covers 12 financial years from 2000 to 2011 and contains 19.6 million firm by year observations (covering 3.8 million firms), including 11.5 million firm by year observations over our study period from 2006-11 (covering 3.1 million firms). Our key SME-eligibility variable from FAME (for R\&D tax relief purpose) is total assets (i.e. balance sheet total). As almost all UK companies are required by the Companies House to send in their balance sheets (either full or simplified) for their annual accounts regardless of their size, total assets coverage in FAME is close to complete, at $97 \%$ over our study period of 2006-11. On the other hand, sales (financial-accounting sales used to determine SME eligibility) is reported by only $15 \%$, as smaller firms are not required to provide their income statements. ${ }^{19}$ The proportion of firms who report employment is even lower at 5\%, as employment reporting is not mandatory. Even in our baseline sample of relatively larger firms (i.e. firms with total assets in 2007 between $€ 61 \mathrm{~m}$ and $€ 111 \mathrm{~m}$ ), the proportion of firms who report sales is $67 \%$ and the proportion who report employment is $55 \%$. For this reason, while we do use FAME sales and employment as running variables in some alternative specifications, our baseline sample and key results are derived using total assets as the running variable.

\footnotetext{
${ }^{17}$ The cash-based method focuses on actual cash receipts rather than their related sales transactions. The accrual methods records sale revenues when they are earned, regardless of whether cash from sales has been collected.

${ }^{18}$ All UK limited companies, public limited companies (PLC), and limited liability partnerships (LLP) are required to file annual accounts with the Companies House. An annual accounts should generally include a balance sheet, an income statement, a director's report, and an audit report. However, smaller companies may be exempt from sending in income statement, director's report, or audit report. All UK registered companies are required to file annual returns with the Companies House, which contain information on registered address and industry codes.

${ }^{19}$ Small companies (those having any 2 of the following: (1) sales of $£ 6.5 \mathrm{~m}$ or less, (2) assets of $£ 3.26 \mathrm{~m}$ or less, (3) 50 employees or less) are only required to send in balance sheets. Micro-entities (those having any 2 of the following: (1) sales of $£ 632,000$ or less, (2) assets of $£ 316,000$ or less, (3) 10 employees or less) are only required to send in simplified balance sheets.
} 
Besides total assets, sales, and employment, other FAME variables used in our paper include primary industry code (UK 4-digit SIC), register address postcode, and fixed assets as a proxy for capital stock.

\section{B.3 PATSTAT dataset}

Our patent data are drawn from the World Patent Statistical Database (PATSTAT) maintained by the European Patent Office (EPO). ${ }^{20}$ PATSTAT is the largest international patent database available to the research community and includes nearly 70 million patent documents from over 60 patent offices, including all of the major offices such as the United States Patent and Trademark office (USPTO), the Japan patent office (JPO) and the Chinese Patent and Trademark Office (SIPO) in addition to the EPO. Therefore, PATSTAT data cover close to the population of all worldwide patents since the 1980s.

PATSTAT reports the name and address of patent applicants, which allows matching individual patents with company databases. The matching between PATSTAT and FAME is implemented by Bureau Van Dijk and is available as part of the ORBIS online platform through a commercial agreement. The quality of the matching is excellent: over our sample period, $94 \%$ of patents filed in the UK and $96 \%$ of patents filed at the EPO have been matched with their owning company.

A patent is a legal title protecting an invention. To be patented, a product or process must be new, involve an inventive step and be susceptible of industrial application. Patents grant their owner a set of rights of exclusivity over an invention. The legal protection conferred by a patent gives its owner the right to exclude others from making, using, selling, offering for sale or importing the patented invention for the term of the patent, which is usually 20 years from the filing date, and in the country or countries where the patent has been filed (and subsequently granted). In addition to the financial and administrative costs of filing, there is a mandatory public disclosure of the description of the technology, which makes imitation easier and facilitates future technological developments.

To make things clearer, consider a simplified invention process. In the first stage, an inventor discovers a new technology. She then decides where to market this invention and how to protect the intellectual property associated with it. A patent in country $i$ grants her an exclusive right to commercially exploit the invention in that country. Accordingly, she will patent her invention in country $i$ if she plans to market it there. The set of patents in different countries related to the same invention is called a patent family. The vast majority of patent families include only one patent (usually in the home country of the inventor). Importantly, PATSTAT reports not only the unique identifier of each patent application, it also indicates a unique patent family indicator for each patent (we use the DOCDB patent family indicator). This allows us to identify all patent applications filed worldwide by UK-based companies and to avoid double-counting inventions that are protected in several countries.

In this study, our primary measure of innovation is the number of patent families - irrespective of where the patents are filed. This proxies for the number of inventions a firm makes. This means that we

\footnotetext{
${ }^{20}$ For further details see http://www.epo.org/searching/subscription/raw/product-14-24.html.
} 
count the number of patents filed anywhere in the world by firms in our sample, be it at the UK Intellectual Property Office, at the European Patent Office, at the USPTO or anywhere else, but we use information on patent families to make sure that any invention patented in several places is only counted once. Patents are sorted by the first year they were filed (the priority year).

We use fractional counts to account for multiple applicants. For example, if two firms jointly apply for a patent, then each firm is attributed one half of a patent. In practice, $8 \%$ of patents filed by UK-based companies are filed jointly by at least two companies.

There are many well-known issues with patents as a measure of innovation. As noted above, not all inventions are patented, although it is reasonable to assume the most valuables are, so counting patents screens out many of the low value inventions. Nevertheless, since patents are of very heterogeneous importance we use several approaches to examine how our results change when looking at patent quality. First, we distinguish between patents filed at the UK patents office and patents files at the EPO ${ }^{21}$ Since the financial and administrative cost is about six times higher at the EPO than UK patent office, EPO patents will, on average be of higher perceived private value. It is also worth noting that the EPO has not experienced the same explosion of low value patents that the US has suffered since the late 1980s (Jaffe and Lerner, 2004)

A second measure of patent quality is the size of patent families, the number of jurisdictions in which each patent is filed. There is evidence that the number of jurisdictions in which a patent is filed is an indicator of its economic value as patenting is costly (see Guellec and van Pottelsberghe, 2000, and Harhoff et al., 2003). A third measure of quality is to distinguish by technology class, as some classes (e.g. pharmaceuticals) are likely to be more valuable than others (e.g. business process methods). Fourth, we use patent citations, also available from PATSTAT. For each patent in the database, we know how many times it was cited by subsequent patents (excluding self-citations). We use the number of subsequent citations (referred to as forward citations) as a measure of value. Again, this measure is well rooted in the patent literature (Hall et al., 2005, Lanjouw and Schankerman, 2004)

In PATSTAT, patents are categorized based on the International Patent Classification (IPC). We use IPC codes at three-digit level to construct measures of the technological distance between firms used to investigate spillover effects.

\section{B.4 Sample construction: merging datasets}

CT600 was merged with FAME using an HMRC-anonymized version of company registration number (CRN), which is a unique regulatory identifier in both datasets. 95\% of CT600 firms between 2006 and 2011 also appear in FAME, covering close to $100 \%$ of R\&D performing firms and $100 \%$ percent

\footnotetext{
${ }^{21}$ Note that because of differences in the "technological scope" of patents across patent offices, two patents filed in the UK may be "merged" into a single patent filed at the EPO. In this case, these three patents will constitute a single patent family and the number of patent families is smaller than the number of UK patents. This configuration happens very rarely, however.
} 
of patenting firms in this period. ${ }^{22}$ Unmatched firms are slightly smaller but not statistically different from matched ones across different variables reported in CT600, including sales, gross trading profits, and gross and net corporate tax chargeable. ${ }^{23}$ Furthermore, that the match rate is less than $100 \%$ is due to CRN entering error in FAME, which happens more often among firms that are much smaller than those around SME-eligibility thresholds. ${ }^{24}$ For these reasons, we believe sample selection due to incomplete matching between CT600 and FAME is unlikely to be an issue for us. ${ }^{25}$

PATSTAT has been merged with FAME by BVD. As PATSAT comprehensively covers all UK patenting firms, we can safely infer that non-matched firms have zero patents. Over our study period of 2006-11, 9,420 out of 2.5 million CT600 firms claim a total of 46,405 patent families (in 17,293 firm by year observations), including 23,617 higher-quality EPO patents. These patents cover $90 \%$ of the total recorded in PATSTAT.

From the merged master dataset, we construct our baseline sample based on total assets in 2007, as it is our key running variable. Specifically, our baseline sample includes 5,888 firms that satisfy the two following conditions: (1) the firm's total assets in 2007 is between $€ 61 \mathrm{~m}$ and $€ 111 \mathrm{~m}$ (within $€ 25 \mathrm{~m}$ below and above the SME threshold of $€ 86 \mathrm{~m}$ ), and (2) the firm appears in CT600 in 2008 or after (to exclude firms exiting before the policy change in 2008). Baseline sample descriptive statistics are summarized in Tables 1 and A2 and discussed in detail in sub-section 4.2.

\section{B.5 Variable construction}

As FAME total assets and sales are reported in sterling while the corresponding SME ceilings are set in euros, we convert sterling to euros using the exact same rule used by HMRC for tax purposes. That is, the conversion should be done using the exchange rate on the last day of the relevant accounting period or the average daily exchange rate throughout that accounting period, whichever is more beneficial for the enterprise. The daily exchange rate is obtained from the OECD, exactly the same method as used by HMRC.

For qualifying R\&D expenditure, we do not include the amounts claimed by SME subcontractors, which do not benefit from more generous reliefs under the SME Scheme. Since SME subcontracting makes up only a small portion of the overall R\&D Tax Relief Scheme, we believe excluding SME subcontracting does not materially affect our key findings. To account for price differences across years,

\footnotetext{
${ }^{22}$ Out of 2,495,944 firms present in CT600 between 2006 and 2011, 2,358,948 firms are matched to FAME (94.5\% match rate). Over the same period, 20,627 out of $20,730 \mathrm{R} \& \mathrm{D}$-performing firms and 9,376 out of 9,420 patenting firms are matched to FAME ( $99.5 \%$ match rate).

${ }^{23}$ Differences (standard errors) between matched and unmatched firms in sales (£'000), gross trading profits $(£)$, gross corporate tax chargeable (£) and net corporate tax chargeable (£) are $970(3,286), 8,969(13,703), 3,497(3,898)$ and 1,961 (2,291) respectively. None of these differences are statistically significant at conventional level.

${ }^{24}$ Because of confidentiality concerns, we do not get to work directly with CRNs but an anonymized version of CRNs provided by the HMRC Datalab for both FAME and CT600 datasets. This prevents us from further cleaning and matching of initially unmatched firms due to above issue.

${ }^{25}$ The correlation between $\ln$ (sales) in CT600 and $\ln$ (sales) FAME is 0.90 . As noted above, the variables are not measured in the same way, but the fact that their correlation is high is reassuring that the match has been performed well.
} 
we also convert nominal values of R\&D expenditure to their real values in 2007 price, using UK annual CPI as reported in the World Bank Economic Indicators database. ${ }^{26}$

We address the presence of outliers in $\mathrm{R} \& \mathrm{D}$ spending or patenting by winsorizing our key outcome variables, which include qualifying R\&D expenditure and number of all patents as well as number of UK patents, EPO patents and patent families. Specifically, for each variable, the top $2.5 \%$ of non-zero values in each year within the sample of firms with 2007 total assets between $€ 46 \mathrm{~m}$ and $€ 126 \mathrm{~m}$ are set to the corresponding 97.5 percentile value (i.e. winsorization at $2.5 \%$ of non-zero values). This translates into "winsorizing" the R\&D of top 5-6 R\&D spenders and the number of patents of top 2-4 patenters in the baseline sample in each year. It should be noted that our key findings are robust to alternative choices of winsorization window (e.g. $1 \%$ or $5 \%$ instead of $2.5 \%$ ), or to excluding outliers instead of winsorizing outcome variables.

Construction of other variables is generally in the notes to tables. Total Factor Productivity (TFP) is calculated by estimating Cobb-Douglas value added functions using the Olley-Pakes method separately by two digit industry using 2000-2005 data (i.e. prior to our estimation period). We also calculated TFP as $\ln ($ value added $)-\left(1-\propto_{l}\right) \ln ($ capital $)-\propto_{l} \ln ($ employment $)$, where $\propto_{l}$ is the share of labor costs in total revenue at the two-digit industry level across all firms in the FAME dataset averaged across the 2006-2011 period as a robustness test. Value added is sales less materials and is are taken from CT600 and capital is fixed assets from FAME. Firm TFP is measured relative to the mean TFP in the two-digit industry.

${ }^{26}$ Ratios of current- $£$ to $2007-£$ derived using UK annual CPI are 1.023 for 2006, 1.000 for 2007, 0.965 for 2008, 0.945 for $2009,0.915$ for 2010 , and 0.875 for 2011 . 
Table A1. Design of UK R\&D Tax Relief Scheme, 2000-2012

\begin{tabular}{|c|c|c|c|c|c|c|c|c|c|}
\hline & & \multicolumn{3}{|c|}{ SME ceilings } & \multicolumn{2}{|c|}{$\begin{array}{c}\text { Enhancement } \\
\text { rate }\end{array}$} & \multicolumn{2}{|c|}{$\begin{array}{l}\text { Payable credit } \\
\text { rate }\end{array}$} & \multirow[b]{2}{*}{ Effective for } \\
\hline \multicolumn{2}{|c|}{ Effective from } & $\begin{array}{c}\text { Employ- } \\
\text { ment }\end{array}$ & $\begin{array}{r}\text { Total } \\
\text { assets }\end{array}$ & $\begin{array}{l}\text { Turn- } \\
\text { over }\end{array}$ & SME & $\begin{array}{l}\text { Large } \\
\text { company }\end{array}$ & SME & $\begin{array}{l}\text { Large } \\
\text { company }\end{array}$ & \\
\hline 2000 & April & 249 & $€ 27 \mathrm{~m}$ & $€ 40 \mathrm{~m}$ & $50 \%$ & $0 \%$ & $16 \%$ & $0 \%$ & $\begin{array}{l}\text { Expenditure that incurred on or after } \\
\text { April } 1^{\text {st }} 2000\end{array}$ \\
\hline 2002 & April & $"$ & $"$ & $"$ & $"$ & $25 \%$ & $"$ & $"$ & $\begin{array}{l}\text { Expenditure that incurred on or after } \\
\text { April } 1^{\text {st }} 2002\end{array}$ \\
\hline 2005 & January & $"$ & $€ 43 \mathrm{~m}$ & $€ 50 \mathrm{~m}$ & $"$ & $"$ & $"$ & $"$ & $\begin{array}{l}\text { Accounting period that ended on or } \\
\text { after January } 1^{\text {st }} 2005\end{array}$ \\
\hline 2008 & $\begin{array}{l}\text { April } \\
\text { August }\end{array}$ & 499 & $€ 86 \mathrm{~m}$ & $€ 100 \mathrm{~m}$ & $75 \%$ & $30 \%$ & $14 \%$ & $"$ & $\begin{array}{l}\text { Large companies: expenditure that } \\
\text { incurred on or after April } 1^{\text {st }} 2008 \\
\text { SMEs: expenditure that incurred on } \\
\text { or after August } 1^{\text {st }} 2008\end{array}$ \\
\hline 2011 & April & $"$ & $"$ & $"$ & $100 \%$ & $"$ & $12.5 \%$ & " & $\begin{array}{l}\text { Expenditure that incurred on or after } \\
\text { April } 1^{\text {st }} 2011\end{array}$ \\
\hline 2012 & April & $"$ & $"$ & $"$ & $125 \%$ & $"$ & $"$ & $"$ & $\begin{array}{l}\text { Expenditure that incurred on or after } \\
\text { April } 1^{\text {st }} 2012\end{array}$ \\
\hline
\end{tabular}

Note: To be considered an SME, a company must fall below the employment ceiling and either the total asset ceiling or the sales ceiling ("ceiling tests"). The measurements and account aggregation rules for employment, total assets, and sales are set according to 1996/280/EC (up to December $31^{\text {st }} 2004$ ) and 2003/361/EC (from January $1^{\text {st }} 2005$ ). A company loses (acquires) its SME status if it fails (passes) the ceiling tests over two consecutive accounting periods (two-year rule). An SME working as subcontractor for a large company can only claim under the Large Company Scheme. From April 2000 to March 2012, there was a minimum requirement of $£ 10,000$ in qualifying R\&D expenditure for both SMEs and large companies. 
Table A2. Baseline sample descriptive statistics, before and after policy change

\begin{tabular}{|c|c|c|c|c|c|c|}
\hline \multirow{2}{*}{$\begin{array}{l}\text { Subsample } \\
\text { Year }\end{array}$} & \multicolumn{2}{|c|}{$\begin{array}{l}\text { Firms with total assets in } \\
2007 \mathrm{~b} / \mathrm{w} € 61-86 \text { million }\end{array}$} & \multicolumn{2}{|c|}{$\begin{array}{l}\text { Firms with total assets in } \\
2007 \mathrm{~b} / \mathrm{w} € 86-111 \text { million }\end{array}$} & \multicolumn{2}{|c|}{$\begin{array}{l}\text { Difference b/w firms with } \\
\text { total assets in } 2007 \\
\text { below vs. above } € 86 \text { million }\end{array}$} \\
\hline & $2006-2008$ & 2009-2011 & $2006-2008$ & $2009-2011$ & $2006-2008$ & $2009-2010$ \\
\hline No. firms with qual. R\&D exp. & 140 & 160 & 84 & 94 & & \\
\hline Avg. qual. R\&D exp. ( $£$ '000) & 4,413 & 4,807 & 7,850 & 6,954 & $-3,437$ & $-2,147$ \\
\hline No. firms with patents & 104 & 99 & 66 & 58 & & \\
\hline Avg. patents & 6.29 & 6.26 & 6.18 & 5.03 & 0.11 & 1.23 \\
\hline No. firms with UK patents & 95 & 91 & 58 & 53 & & \\
\hline Avg. UK patents & 8.97 & 8.18 & 8.70 & 6.66 & 0.27 & 1.52 \\
\hline No. firms with EPO patents & 72 & 54 & 44 & 37 & & \\
\hline Avg. EPO patents & 4.77 & 5.52 & 4.82 & 4.35 & -0.05 & 1.17 \\
\hline Total no. firms in the subsample & & & & & & \\
\hline Avg. qual. R\&D exp. ( $\left(f^{\prime} 000\right)$ & 173.5 & 216.0 & 283.4 & 280.9 & -109.9 & -64.9 \\
\hline Avg. patents & 0.184 & 0.174 & 0.175 & 0.125 & 0.009 & 0.049 \\
\hline Avg. UK patents & 0.239 & 0.209 & 0.217 & 0.152 & 0.022 & 0.057 \\
\hline Avg. EPO patents & 0.097 & 0.084 & 0.091 & 0.069 & 0.006 & 0.015 \\
\hline
\end{tabular}

Note: The baseline sample includes 5,888 firms with total assets in 2007 between $€ 61 \mathrm{~m}$ and $€ 111 \mathrm{~m}$. Total assets data come from FAME and are converted to $€$ from $£$ using HMRC rule. Qualifying R\&D expenditure comes from CT600 panel dataset and are converted to 2007 prices. Patent counts come from PATSTAT. 
$\underline{\text { Table A3. Robustness checks for } R \& D \text { regressions }}$

Panel A.
(1)
(2)
(3)
(4)
(5)
(6)
(7)
(8)
(9)
(10)

Dependent variable

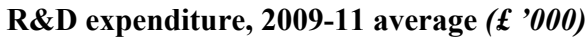

\begin{tabular}{lr} 
Specification & $\begin{array}{r}\text { Pooling } \\
2009-11\end{array}$ \\
\hline
\end{tabular}

Below new SME asset $138.5^{* *}$

Higher order Lagged dependent

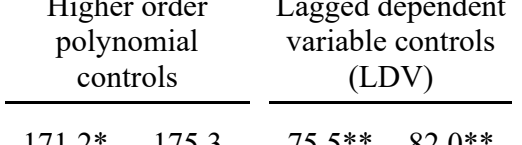

threshold in 2007

(55.3)

$171.2 * \quad 175.3$

$75.5 * * \quad 82.0 * *$

Industry \& location

Past qualifying R\&D

(87.4) (108.0)

(37.6) (36.4)

$0.66 * * * 0.89 * * *$

fixed effects specification

expenditure $\left(£^{\prime} 000\right)$

$(0.08) \quad(0.09)$

Polynomial controls

$1^{\text {st }}$ order $2^{\text {nd }}$ order $3^{\text {rd }}$ order

$1^{\text {st }}$ order $1^{\text {st }}$ order

$1^{\text {st }}$ order $1^{\text {st }}$ order $1^{\text {st }}$ order

$1^{\text {st }}$ order $1^{\text {st }}$ order

Year of LDV

2007 2006-08

2007

Fixed effects

Year

Industry Location Ind. $\mathrm{x}$ loc.

Firms

17,664

$5,888 \quad 5,888$

$5,888 \quad 5,888$

$4,502 \quad 5,768$

4,466

Panel B.

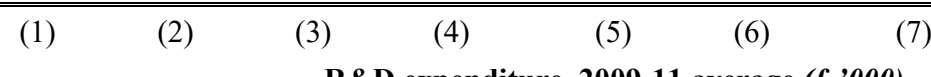

R\&D expenditure, 2009-11 average ( $£$ '000)

Dependent variable

Alternative bandwidth
around the threshold

Specification

Below asset dummy
threshold (in 2007)

$77.9 * 143.2 * * \quad 182 * *$

(46.9)

(58.4)

(73.5)

51-121m 56-116m 66-106m 71-101m

Ep

Sample total assets

Kernel weight

Winsorization window

$2.5 \%$

$2.5 \%$

$2.5 \%$

$2.5 \%$

$2.5 \%$

8,818

7,255

4,61

3,384

5,888

5,888

$\frac{\begin{array}{c}\text { Alternative kernel } \\ \text { weight }\end{array}}{148.6^{* *} 151.9^{* *}}$

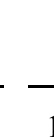

Alternative winsorization parameter

$(57.8) \quad(60.8)$

(68.1)

$(42.2)$

Note: $* * *$ significant at $1 \%$ level, ** 5\% level, * $10 \%$ level. OLS estimates based on the RD design. The running variable is total assets in 2007 with a threshold of $€ 86 \mathrm{~m}$. Baseline sample includes firms in 2007 within $€ 25 \mathrm{~m}$ below and above the cut-off (i.e. between $€ 61 \mathrm{~m}$ and $€ 111 \mathrm{~m}$ ). Controls for first order polynomials of running variable separately for each side of the threshold are included. Robust standard errors are in brackets. Panel A: Column 1 pools observations across 2009-11 with year dummies and standard errors clustered at firm level. Columns 2-3 control for second or third order polynomials of running variable. Columns 4-5 add lagged dependent variable controls. Columns 6-8 add industry (4-digit SIC), location (2-digit postcode), and industry $\mathrm{x}$ location (2-digit SIC x 1-digit postcode) fixed effects. Columns 9-10 use Poisson specification instead of OLS, without (column 9) and with (column 10) lagged dependent variable control. Panel B: Columns 1-4 use samples with different sample bandwidths around the threshold. Columns 5-6 use Epanechnikov or triangular kernel weights. Columns 7-9 use samples with different winsorization parameters or sample excluding outliers in R\&D expenditure. 
Table A4. Robustness checks for reduced-form patent regressions

Panel A.
(1)
(2)
(3)
(4)
(5)
(6)
(7)
(8)
(9)
(10)

Dependent variable All patent count, 2009-11 average

\begin{tabular}{|c|c|c|c|c|c|c|c|c|c|c|}
\hline \multirow{3}{*}{$\begin{array}{l}\text { Specification } \\
\text { Below new SME asset } \\
\text { threshold in } 2007\end{array}$} & \multirow{3}{*}{$\begin{array}{c}\text { Pooling } \\
2009-11 \\
0.073 * * * \\
(0.026)\end{array}$} & \multicolumn{2}{|c|}{$\begin{array}{l}\text { Higher order } \\
\text { polynomial } \\
\text { controls }\end{array}$} & \multicolumn{2}{|c|}{$\begin{array}{l}\text { Lagged dependent } \\
\text { variable controls } \\
\text { (LDV) }\end{array}$} & \multicolumn{3}{|c|}{$\begin{array}{l}\text { Industry \& location } \\
\text { fixed effects }\end{array}$} & \multicolumn{2}{|c|}{$\begin{array}{c}\text { Poisson } \\
\text { specification }\end{array}$} \\
\hline & & 0.067 & 0.067 & $0.041 * *$ & $0.043 * *$ & $0.069 *$ & $0.075 * * *$ & $0.092 * * *$ & $1.52 * * *$ & $1.42 * *$ \\
\hline & & $(0.046)$ & $(0.054)$ & $(0.021)$ & $(0.018)$ & $(0.035)$ & $(0.027)$ & $(0.031)$ & $(0.50)$ & $(0.57)$ \\
\hline \multirow{2}{*}{$\begin{array}{l}\text { Past qualifying R\&D } \\
\text { expenditure }\left(£^{\prime} 000\right)\end{array}$} & & & & \multirow{2}{*}{\multicolumn{2}{|c|}{$\begin{array}{c}0.738 * * * 0.811 * * * \\
(0.109) \quad(0.010)\end{array}$}} & & & & & \\
\hline & & & & & & & & & & \\
\hline \multirow{3}{*}{$\begin{array}{l}\text { Polynomial controls } \\
\text { Year of LDV } \\
\text { Fixed effects }\end{array}$} & $1^{\text {st }}$ order & $2^{\text {nd }}$ order & $3^{\text {rd }}$ order & \multirow{3}{*}{\multicolumn{2}{|c|}{$\begin{array}{cc}1^{\text {st }} \text { order } & 1^{\text {st }} \text { order } \\
2007 & 2006-08\end{array}$}} & \multirow[t]{2}{*}{$1^{\text {st }}$ order } & \multirow[t]{2}{*}{$1^{\text {st }}$ order } & \multirow[t]{2}{*}{$1^{\text {st }}$ order } & \multirow[t]{2}{*}{$1^{\text {st }}$ order } & $1^{\text {st }}$ order \\
\hline & & & & & & & & & & 2007 \\
\hline & Year & & & & & Industry & Location & Ind. $x$ loc. & & \\
\hline Firms & 17,664 & 5,888 & 5,888 & 5,888 & 5,888 & 4,502 & 5,768 & 4,466 & 5,888 & 5,888 \\
\hline
\end{tabular}

Panel B.

$\begin{array}{llllllll}(1) & (2) & (3) & (4) & (5) & (6) & \text { (7) } & \text { (8) }\end{array}$

Dependent variable

All patent count, 2009-11 average

\begin{tabular}{|c|c|c|c|c|c|c|c|c|c|}
\hline \multirow{2}{*}{$\begin{array}{l}\text { Specification } \\
\text { Below asset threshold } \\
\text { dummy (in 2007) }\end{array}$} & \multicolumn{4}{|c|}{$\begin{array}{l}\text { Alternative bandwidth } \\
\text { around the threshold }\end{array}$} & \multicolumn{2}{|c|}{$\begin{array}{c}\text { Alternative kernel } \\
\text { weight }\end{array}$} & \multicolumn{3}{|c|}{$\begin{array}{l}\text { Alternative winsorization } \\
\text { parameter }\end{array}$} \\
\hline & $\begin{array}{l}0.045^{*} \\
(0.025)\end{array}$ & $\begin{array}{c}0.076 * * * \\
(0.027)\end{array}$ & $\begin{array}{l}0.067 * * \\
(0.029)\end{array}$ & $\begin{array}{c}0.071 \\
(0.049)\end{array}$ & $\begin{array}{c}0.071 * * * \\
(0.027)\end{array}$ & $\begin{array}{l}0.07 * * \\
(0.029)\end{array}$ & $\begin{array}{l}0.07 * * \\
(0.027)\end{array}$ & $\begin{array}{c}0.073 * * * \\
(0.025)\end{array}$ & $\begin{array}{c}0.074 * * * \\
(0.025)\end{array}$ \\
\hline $\begin{array}{l}\text { Sample total assets } \\
\text { Kernel weight }\end{array}$ & $51-121 \mathrm{~m}$ & $56-116 \mathrm{~m}$ & $66-106 \mathrm{~m}$ & $71-101 \mathrm{~m}$ & $\begin{array}{c}\text { 61-111m } \\
\text { Epa }\end{array}$ & $\begin{array}{c}\text { 61-111m } \\
\text { Tri }\end{array}$ & $61-111 m$ & $61-111 \mathrm{~m}$ & $61-111 \mathrm{~m}$ \\
\hline Winsorization window & $2.5 \%$ & $2.5 \%$ & $2.5 \%$ & $2.5 \%$ & $2.5 \%$ & $2.5 \%$ & $1.0 \%$ & $5.0 \%$ & no outliers \\
\hline Firms & 8,818 & 7,255 & 4,615 & 3,384 & 5,888 & 5,888 & 5,888 & 5,888 & 5,884 \\
\hline
\end{tabular}

Note: $* * *$ significant at $1 \%$ level, $* * 5 \%$ level, $* 10 \%$ level. OLS estimates based on the RD design. The running variable is total assets in 2007 with a threshold of $€ 86 \mathrm{~m}$. Baseline sample includes firms with total assets in 2007 within $€ 25 \mathrm{~m}$ below and above the cut-off (i.e. between $€ 61 \mathrm{~m}$ and $€ 111 \mathrm{~m}$ ). Controls for first order polynomials of running variable separately for each side of the threshold are included. Robust standard errors are in brackets. Panel A: Column 1 pools observations across 200911 with year fixed effects and standard errors clustered at firm level. Columns 2-3 control for second or third order polynomials of running variable. Columns 4-5 add lagged dependent variable controls. Columns 6-8 add industry (4-digit SIC), location (2digit postcode), and industry x location (2-digit SIC x 1-digit postcode) fixed effects. Columns 9-10 use Poisson specification instead of OLS, without (column 9) and with (column 10) lagged dependent variable control. Panel B: Columns 1-4 use samples with different sample bandwidths around the threshold. Columns 5-6 use Epanechnikov or triangular kernel weights. Columns 7-9 use samples with different winsorization parameters or sample excluding outliers in R\&D expenditure. 
Table A5. Robustness checks for effects of R\&D Tax Relief Scheme on patents (IV regressions)

Panel A.
(1)
(2)
(3)
(4)
(5)
(6)
(7)
(8)

Dependent variable

Total all patents filed over 2009-11

\begin{tabular}{|c|c|c|c|c|c|c|c|c|}
\hline \multirow{2}{*}{$\begin{array}{l}\text { Specification } \\
\begin{array}{l}\text { Qual. R\&D expenditure } \\
\text { over 2009-11 ( } £ \text { mill) }\end{array}\end{array}$} & \multirow{2}{*}{$\begin{array}{l}\text { Pooling } \\
2009-11 \\
0.530 * * \\
(0.254)\end{array}$} & \multicolumn{2}{|c|}{$\begin{array}{c}\text { Higher order } \\
\text { polynomial controls }\end{array}$} & \multicolumn{2}{|c|}{$\begin{array}{l}\text { Lagged dependent } \\
\text { variable controls } \\
\text { (LDV) }\end{array}$} & \multicolumn{3}{|c|}{$\begin{array}{l}\text { Industry \& location } \\
\text { fixed effects }\end{array}$} \\
\hline & & $\begin{array}{c}0.391 \\
(0.292)\end{array}$ & $\begin{array}{c}0.382 \\
(0.336)\end{array}$ & $\begin{array}{c}0.331 \\
(0.208)\end{array}$ & $\begin{array}{l}0.335^{*} \\
(0.194)\end{array}$ & $\begin{array}{c}0.549 \\
(0.360)\end{array}$ & $\begin{array}{l}0.702 * * \\
(0.354)\end{array}$ & $\begin{array}{c}1.48^{*} \\
(0.884)\end{array}$ \\
\hline $\begin{array}{l}\text { Past qualifying R\&D } \\
\text { expenditure ( } £ \text { mill })\end{array}$ & & & & $\begin{array}{c}0.635^{* * *} \\
(0.125)\end{array}$ & $\begin{array}{c}0.708 * * * \\
(0.122)\end{array}$ & & & \\
\hline $\begin{array}{l}\text { Polynomial controls } \\
\text { Year of LDV }\end{array}$ & $1^{\text {st }}$ order & $2^{\text {nd }}$ order & $3^{\text {rd }}$ order & $\begin{array}{c}1^{\text {st }} \text { order } \\
2007\end{array}$ & $\begin{array}{l}1^{\text {st }} \text { order } \\
2006-08\end{array}$ & $1^{\text {st }}$ order & $1^{\text {st }}$ order & $1^{\text {st }}$ order \\
\hline Fixed effects & Year & & & & & Industry & Location & Ind. $\mathrm{x}$ loc. \\
\hline Observations & 17,664 & 5,888 & 5,888 & 5,888 & 5,888 & 4,502 & 5,768 & 4,466 \\
\hline
\end{tabular}

Panel B.

$\begin{array}{llllllll}(1) & (2) & (3) & (4) & (5) & (6) & \text { (7) } & \text { (8) }\end{array}$

Dependent variable

All patents filed, 2009-11 average

\begin{tabular}{|c|c|c|c|c|c|c|c|c|c|}
\hline \multirow{2}{*}{$\begin{array}{l}\text { Specification } \\
\text { R\&D exp. ( } £ \text { mill), } \\
2009-11 \text { average }\end{array}$} & \multicolumn{4}{|c|}{$\begin{array}{l}\text { Alternative bandwidth } \\
\text { around the threshold }\end{array}$} & \multicolumn{2}{|c|}{$\begin{array}{c}\text { Alternative kernel } \\
\text { weight }\end{array}$} & \multicolumn{3}{|c|}{$\begin{array}{l}\text { Alternative winsorization } \\
\text { parameter }\end{array}$} \\
\hline & $\begin{array}{c}1.03 \\
(1.07)\end{array}$ & $\begin{array}{c}0.978 \\
(0.625)\end{array}$ & $\begin{array}{l}0.465^{*} \\
(0.250)\end{array}$ & $\begin{array}{c}0.388 \\
(0.270)\end{array}$ & $\begin{array}{l}0.478 * * \\
(0.234)\end{array}$ & $\begin{array}{l}0.464 * * \\
(0.235)\end{array}$ & $\begin{array}{l}0.429 * * \\
(0.210)\end{array}$ & $\begin{array}{l}0.711 * * \\
(0.335)\end{array}$ & $\begin{array}{l}0.350 * \\
(0.179)\end{array}$ \\
\hline $\begin{array}{l}\text { Sample total assets } \\
\text { Kernel weight }\end{array}$ & $51-121 \mathrm{~m}$ & $56-116 \mathrm{~m}$ & $66-106 \mathrm{~m}$ & $71-101 \mathrm{~m}$ & $\begin{array}{c}\text { 61-111m } \\
\text { Epa }\end{array}$ & $\begin{array}{c}\text { 61-111m } \\
\text { Tri }\end{array}$ & $61-111 \mathrm{~m}$ & $61-111 \mathrm{~m}$ & $61-111 \mathrm{~m}$ \\
\hline Winsorization window & $2.5 \%$ & $2.5 \%$ & $2.5 \%$ & $2.5 \%$ & $2.5 \%$ & $2.5 \%$ & $1.0 \%$ & $5.0 \%$ & no outliers \\
\hline Firms & 8,818 & 7,255 & 4,615 & 3,384 & 5,888 & 5,888 & 5,888 & 5,888 & 5,884 \\
\hline
\end{tabular}

Note: *** significant at $1 \%$ level, $* * 5 \%$ level, $* 10 \%$ level. IV estimates based on the (fuzzy) RD design. Instrumental variable is the dummy whether total assets in 2007 is below $€ 86 \mathrm{~m}$. Baseline sample includes firms with total assets in 2007 within $€ 25 \mathrm{~m}$ below and above the cut-off (i.e. between $€ 61 \mathrm{~m}$ and $€ 11 \mathrm{~m}$ ). Controls for first order polynomials of the running variable (total assets in 2007) separately for each side of the threshold are included. Robust standard errors are in brackets. Panel A: Column 1 pools observations across 2009-11 with year fixed effects and standard errors clustered at firm level. Columns 2-3 control for second or third order polynomials of running variable. Columns 4-5 add lagged dependent variable controls. Columns 6-8 add industry (4-digit SIC), location (2-digit postcode), and industry x location (2-digit SIC x 1-digit postcode) fixed effects. Panel B: Columns 1-4 use samples with different sample bandwidths around the threshold. Columns 5-6 use Epanechnikov or triangular kernel weights. Columns 7-9 use samples with different winsorization parameters or sample excluding outliers in R\&D expenditure. 
Table A6. Discontinuities in the probabilities of doing any R\&D or filing any patents

\begin{tabular}{|c|c|c|c|c|c|c|}
\hline \multirow{3}{*}{ Year } & (1) & (2) & (3) & (4) & (5) & (6) \\
\hline & \multicolumn{3}{|c|}{ Before (pre-policy) } & \multicolumn{3}{|c|}{ After (post-policy) } \\
\hline & 2006 & 2007 & 2008 & 2009 & 2010 & 2011 \\
\hline Dependent variable & \multicolumn{6}{|c|}{ Dummy: $R \& D$ expenditure $>0$} \\
\hline $\begin{array}{l}\text { Below asset threshold } \\
\text { dummy (in 2007) }\end{array}$ & $\begin{array}{c}0.011 \\
(0.008)\end{array}$ & $\begin{array}{l}0.016^{*} \\
(0.009)\end{array}$ & $\begin{array}{l}-0.0045 \\
(0.009)\end{array}$ & $\begin{array}{c}0.007 \\
(0.009)\end{array}$ & $\begin{array}{c}0.002 \\
(0.010)\end{array}$ & $\begin{array}{c}0.010 \\
(0.010)\end{array}$ \\
\hline Mean over 2006-08 & 0.021 & 0.026 & 0.029 & 0.028 & 0.030 & 0.031 \\
\hline Dependent variable & \multicolumn{6}{|c|}{ Dummy: All patent count $>0$} \\
\hline $\begin{array}{l}\text { Below asset threshold } \\
\text { dummy (in 2007) }\end{array}$ & $\begin{array}{c}0.006 \\
(0.008)\end{array}$ & $\begin{array}{c}0.009 \\
(0.007)\end{array}$ & $\begin{array}{l}0.0040 \\
(0.006)\end{array}$ & $\begin{array}{l}0.011^{*} \\
(0.007)\end{array}$ & $\begin{array}{c}0.008 \\
(0.007)\end{array}$ & $\begin{array}{l}0.012 * \\
(0.007)\end{array}$ \\
\hline Mean over 2006-08 & 0.021 & 0.020 & 0.015 & 0.016 & 0.017 & 0.015 \\
\hline Firms & 5,888 & 5,888 & 5,888 & 5,888 & 5,888 & 5,888 \\
\hline
\end{tabular}

Note: *** significant at $1 \%$ level, $* * 5 \%$ level, * $10 \%$ level. OLS estimates based on the RD design. The running variable is total assets in 2007 with a threshold of $€ 86 \mathrm{~m}$. Baseline sample includes firms with total assets in 2007 within $€ 25 \mathrm{~m}$ below and above the cut-off (i.e. between $€ 61 \mathrm{~m}$ and $€ 11 \mathrm{~m}$ ). Controls for first order polynomials of running variable separately for each side of the threshold are included. Robust standard errors are in brackets. Dependent variables are dummies indicating whether a firm has $R \& D$ expenditure or files patents during the corresponding year.

Table A7. Heterogeneous effects of R\&D Tax Relief Scheme by past R\&D and patents

\begin{tabular}{|c|c|c|c|c|c|c|c|c|}
\hline \multirow{4}{*}{$\begin{array}{l}\text { Specification } \\
\text { Dependent variable } \\
\text { (2009-11 average) } \\
\text { Subsample }\end{array}$} & $(1)$ & $(2)$ & (3) & (4) & $(5)$ & $(6)$ & $(7)$ & $(8)$ \\
\hline & \multirow{2}{*}{\multicolumn{2}{|c|}{$\begin{array}{c}\text { First stage OLS } \\
\text { R\&D expenditure } \\
(\boldsymbol{E}, 000)\end{array}$}} & \multicolumn{6}{|c|}{ Reduced form OLS } \\
\hline & & & \multicolumn{2}{|c|}{ All patents counts } & \multicolumn{2}{|c|}{ UK patent counts } & \multicolumn{2}{|c|}{ EPO patent counts } \\
\hline & $\begin{array}{c}\text { Past R\&D } \\
>0\end{array}$ & $\begin{array}{c}\text { Past R\&D } \\
=0\end{array}$ & $\begin{array}{l}\text { Past all } \\
\text { pat. }>0\end{array}$ & $\begin{array}{l}\text { Past all } \\
\text { pat. }=0\end{array}$ & $\begin{array}{l}\text { Past UK } \\
\text { pat. }>0\end{array}$ & $\begin{array}{c}\text { Past UK } \\
\text { pat. }=0\end{array}$ & $\begin{array}{c}\text { Past EPO } \\
\text { pat. }>0\end{array}$ & $\begin{array}{c}\text { Past EPO } \\
\text { pat. }=0\end{array}$ \\
\hline $\begin{array}{l}\text { Below asset threshold } \\
\text { dummy (in 2007) }\end{array}$ & $\begin{array}{c}2,775^{* *} \\
(1,134)\end{array}$ & $\begin{array}{c}0.0 \\
(7.1)\end{array}$ & $\begin{array}{c}1.80^{* * *} \\
(0.66)\end{array}$ & $\begin{array}{c}0.00 \\
(0.00)\end{array}$ & $\begin{array}{c}2.52 * * * \\
(0.91)\end{array}$ & $\begin{array}{c}0.00 \\
(0.01)\end{array}$ & $\begin{array}{l}1.58 * * \\
(0.61)\end{array}$ & $\begin{array}{c}0.00 \\
(0.00)\end{array}$ \\
\hline Mean over 2006-08 & 1,901 & 0.0 & 2.08 & 0.00 & 2.96 & 0.00 & 1.60 & 0.00 \\
\hline $\begin{array}{l}\text { Difference between having } \\
\text { vs. not having } R \& D / \text { patents }\end{array}$ & \multicolumn{2}{|c|}{$\begin{array}{l}2,775 \\
(1,125)\end{array}$} & \multicolumn{2}{|c|}{$\begin{array}{c}1.80 * * * \\
(0.65)\end{array}$} & \multicolumn{2}{|c|}{$\begin{array}{c}2.52 * * * \\
(0.90)\end{array}$} & \multicolumn{2}{|c|}{$\begin{array}{l}1.58 * * \\
(0.60)\end{array}$} \\
\hline Firms & 224 & 5,664 & 170 & 5,718 & 153 & 5,735 & 116 & 5,772 \\
\hline
\end{tabular}

Note: $* * *$ significant at $1 \%$ level, $* * 5 \%$ level, $* 10 \%$ level. OLS estimates based on the RD design. The running variable is total assets in 2007 with a threshold of $€ 86 \mathrm{~m}$. Baseline sample includes firms with total assets in 2007 within $€ 25 \mathrm{~m}$ below and above the cut-off (i.e. between $€ 61 \mathrm{~m}$ and $€ 111 \mathrm{~m}$ ). Controls for first order polynomials of running variable separately for each side of the threshold are included. Robust standard errors are in brackets. 
Table A8. Heterogeneous effects of R\&D Tax Relief Scheme by industry patenting intensity

Panel A.

\begin{tabular}{|c|c|c|c|c|c|c|c|c|}
\hline \multirow{4}{*}{$\begin{array}{l}\text { Specification } \\
\text { Dependent variable } \\
\text { (2009-11 average) } \\
\text { Subsample }\end{array}$} & (1) & (2) & (3) & (4) & (5) & (6) & (7) & (8) \\
\hline & \multirow{2}{*}{\multicolumn{2}{|c|}{$\begin{array}{c}\text { First stage OLS } \\
\text { R\&D expenditure } \\
(\mathfrak{f} \text { '000) }\end{array}$}} & \multicolumn{6}{|c|}{ Reduced form OLS } \\
\hline & & & \multicolumn{2}{|c|}{ All patent count } & \multicolumn{2}{|c|}{ UK patent count } & \multicolumn{2}{|c|}{ EPO patent count } \\
\hline & $\begin{array}{c}\text { High } \\
\text { patent }\end{array}$ & $\begin{array}{l}\text { Low } \\
\text { patent }\end{array}$ & $\begin{array}{l}\text { High } \\
\text { patent }\end{array}$ & $\begin{array}{l}\text { Low } \\
\text { patent }\end{array}$ & $\begin{array}{l}\text { High } \\
\text { patent }\end{array}$ & $\begin{array}{l}\text { Low } \\
\text { patent }\end{array}$ & $\begin{array}{l}\text { High } \\
\text { patent }\end{array}$ & $\begin{array}{c}\text { Low } \\
\text { patent }\end{array}$ \\
\hline $\begin{array}{l}\text { Below asset threshold } \\
\text { dummy (in 2007) }\end{array}$ & $\begin{array}{l}204.6^{*} \\
(106.3)\end{array}$ & $\begin{array}{l}100.6 \\
(67.9)\end{array}$ & $\begin{array}{l}0.16^{* *} \\
(0.06)\end{array}$ & $\begin{array}{c}0.02 \\
(0.01)\end{array}$ & $\begin{array}{l}0.21 * * \\
(0.08)\end{array}$ & $\begin{array}{c}0.02 \\
(0.02)\end{array}$ & $\begin{array}{l}0.08 * \\
(0.04)\end{array}$ & $\begin{array}{c}0.01 \\
(0.01)\end{array}$ \\
\hline Mean over 2006-08 & 117.0 & 22.3 & 0.12 & 0.01 & 0.15 & 0.02 & 0.06 & 0.01 \\
\hline $\begin{array}{l}\text { Difference between high vs. } \\
\text { low patenting industries }\end{array}$ & \multicolumn{2}{|c|}{$\begin{array}{c}104.0 \\
(126.1)\end{array}$} & \multicolumn{2}{|c|}{$\begin{array}{l}0.14 * * \\
(0.07)\end{array}$} & \multicolumn{2}{|c|}{$\begin{array}{l}0.19^{* *} \\
(0.08)\end{array}$} & \multicolumn{2}{|c|}{$\begin{array}{c}0.06 \\
(0.04)\end{array}$} \\
\hline Firms & 2,273 & 2,231 & 2,273 & 2,231 & 2,273 & 2,231 & 2,273 & 2,231 \\
\hline
\end{tabular}

Panel B.

$\begin{array}{llllll}(1) & (2) & (3) & & (4) & (5)\end{array}$

Specification

Dependent variable (2009-11 average)

All patent count

Subsample

R\&D expenditure (£ million),

2009-11 average

Firms

Note: is calculated as the share of firms in the industry (at the 4-digit SIC level) having filed any patent before 2007. Panel A: OLS estimates based on the RD design. The running variable is total assets in 2007 with a threshold of $€ 86 \mathrm{~m}$. Baseline sample includes firms with total assets in 2007 within $€ 25 \mathrm{~m}$ below and above the cut-off (i.e. between $€ 61 \mathrm{~m}$ and $€ 111 \mathrm{~m}$ ). Controls for first order polynomials of running variable separately for each side of the threshold are included. Panel B: IV estimates based on the (fuzzy) RD design. Instrumental variable is the dummy whether total assets in 2007 is below $€ 86 \mathrm{~m}$. Baseline sample includes firms with total assets in 2007 within $€ 25 \mathrm{~m}$ below and above the cut-off (i.e. between $€ 61 \mathrm{~m}$ and $€ 111 \mathrm{~m}$ ). Controls for first order polynomials of RDD running variable (total assets in 2007) separately for each side of the threshold are included. 
Table A9. Heterogeneous effects of R\&D Tax Relief Scheme by firms' past capital investments

Panel A.

\begin{tabular}{|c|c|c|c|c|c|c|c|c|}
\hline \multirow{4}{*}{$\begin{array}{l}\text { Specification } \\
\text { Dependent variable } \\
\text { (2009-11 average) } \\
\text { Sample industries }\end{array}$} & (1) & (2) & (3) & (4) & (5) & (6) & (7) & (8) \\
\hline & \multirow{2}{*}{\multicolumn{2}{|c|}{$\begin{array}{c}\text { First stage OLS } \\
\mathbf{R} \& \mathbf{D} \text { expenditure } \\
(\boldsymbol{E}, 000)\end{array}$}} & \multicolumn{6}{|c|}{ Reduced form OLS } \\
\hline & & & \multicolumn{2}{|c|}{ All patent count } & \multicolumn{2}{|c|}{ UK patent count } & \multicolumn{2}{|c|}{ EPO patent count } \\
\hline & $\begin{array}{c}\text { Past } \\
\text { inv. }>0\end{array}$ & $\begin{array}{c}\text { Past } \\
\text { inv. }=0\end{array}$ & $\begin{array}{c}\text { Past } \\
\text { inv. }>0\end{array}$ & $\begin{array}{c}\text { Past } \\
\text { inv. }=0\end{array}$ & $\begin{array}{c}\text { Past } \\
\text { inv. }>0\end{array}$ & $\begin{array}{c}\text { Past } \\
\text { inv. }=0\end{array}$ & $\begin{array}{c}\text { Past } \\
\text { inv. }>0\end{array}$ & $\begin{array}{c}\text { Past } \\
\text { inv. }=0\end{array}$ \\
\hline $\begin{array}{l}\text { Below asset threshold } \\
\text { dummy (in 2007) }\end{array}$ & $\begin{array}{c}338.3 * * * \\
(113.9)\end{array}$ & $\begin{array}{l}-37.7 \\
(32.2)\end{array}$ & $\begin{array}{c}0.16^{* * *} \\
(0.05)\end{array}$ & $\begin{array}{c}0.00 \\
(0.02)\end{array}$ & $\begin{array}{c}0.21 * * * \\
(0.07)\end{array}$ & $\begin{array}{c}0.00 \\
(0.02)\end{array}$ & $\begin{array}{r}0.08^{* *} \\
(0.03)\end{array}$ & $\begin{array}{c}0.00 \\
(0.01)\end{array}$ \\
\hline Mean over 2006-08 & 153.9 & 5.6 & 0.12 & 0.01 & 0.15 & 0.02 & 0.06 & 0.01 \\
\hline $\begin{array}{l}\text { Difference between high vs. } \\
\text { low investment firms }\end{array}$ & \multicolumn{2}{|c|}{$\begin{array}{l}376.0 * * * \\
(118.4)\end{array}$} & \multicolumn{2}{|c|}{$\begin{array}{c}0.16^{* * *} \\
(0.06)\end{array}$} & \multicolumn{2}{|c|}{$\begin{array}{c}0.21 * * * \\
(0.07)\end{array}$} & \multicolumn{2}{|c|}{$\begin{array}{l}0.08 * * \\
(0.04)\end{array}$} \\
\hline Firms & 2,655 & 3,042 & 2,655 & 3,042 & 2,655 & 3,042 & 2,655 & 3,042 \\
\hline
\end{tabular}

Panel B.

(1)

(2)

Specification

Dependent variable (2009-11 average)

Subsample

R\&D expenditure (£ million), 2009-11 average

Firms

2,655

3,042

2,655

3,042

(4)

(5)

(6)

IV

Note: $* * *$ significant at $1 \%$ level, $* * 5 \%$ level, $* 10 \%$ level. Robust standard errors are in brackets. Past capital investments is calculated as average machinery and plant investments over 2005-07. Panel A: OLS estimates based on the RD design. The running variable is total assets in 2007 with a threshold of $€ 86 \mathrm{~m}$. Baseline sample includes firms with total assets in 2007 within $€ 25 \mathrm{~m}$ below and above the cut-off (i.e. between $€ 61 \mathrm{~m}$ and $€ 111 \mathrm{~m}$ ). Controls for first order polynomials of running variable separately for each side of the threshold are included. Panel B: IV estimates based on the RD design. Instrumental variable is the dummy whether total assets in 2007 is below $€ 86 \mathrm{~m}$. Baseline sample includes firms with total assets in 2007 within $€ 25 \mathrm{~m}$ below and above the cut-off (i.e. between $€ 61 \mathrm{~m}$ and $€ 111 \mathrm{~m}$ ). Controls for first order polynomials of RDD running variable (total assets in 2007) separately for each side of the threshold are included. 
Table A10. Estimating impacts of R\&D Tax Relief Scheme using other SME criteria

Panel A.

\begin{tabular}{|c|c|c|c|c|c|c|c|c|}
\hline \multirow{3}{*}{$\begin{array}{l}\text { SME criterion } \\
\text { Dependent variable } \\
\text { (2009-2011 average) }\end{array}$} & (1) & (2) & (3) & (4) & (5) & (6) & (7) & (8) \\
\hline & \multicolumn{2}{|c|}{ Total assets } & \multicolumn{4}{|c|}{ Sales } & \multicolumn{2}{|c|}{ Employment } \\
\hline & $\begin{array}{c}\text { R\&D exp. } \\
(\notin \cdot 000)\end{array}$ & $\begin{array}{c}\text { All patent } \\
\text { count }\end{array}$ & $\begin{array}{c}\text { R\&D exp. } \\
(£ \cdot 000)\end{array}$ & $\begin{array}{c}\text { All patent } \\
\text { count }\end{array}$ & $\begin{array}{c}\text { R\&D exp. } \\
(\notin \cdot 000)\end{array}$ & $\begin{array}{c}\text { All patent } \\
\text { count }\end{array}$ & $\begin{array}{c}\text { R\&D exp. } \\
(\notin \cdot 000) \\
\end{array}$ & $\begin{array}{c}\text { All patent } \\
\text { count }\end{array}$ \\
\hline $\begin{array}{l}\text { Below SME threshold } \\
\text { dummy (in 2007) }\end{array}$ & $\begin{array}{c}138.5 * * \\
(55.3)\end{array}$ & $\begin{array}{c}0.073 * * * \\
(0.026)\end{array}$ & $\begin{array}{c}133.9 * * \\
(66.5)\end{array}$ & $\begin{array}{c}0.035 \\
(0.050)\end{array}$ & $\begin{array}{c}133.0 \\
(129.6)\end{array}$ & $\begin{array}{c}0.109 \\
(0.071)\end{array}$ & $\begin{array}{c}77.2 \\
(114.3)\end{array}$ & $\begin{array}{l}0.120^{*} \\
(0.062)\end{array}$ \\
\hline Mean over 2006-08 & 72.3 & 0.060 & 105.2 & 0.083 & 176.9 & 0.114 & 197.6 & 0.141 \\
\hline $\begin{array}{l}\text { Treatment effect to } \\
\text { baseline ratio }\end{array}$ & 1.92 & 1.22 & 1.27 & 0.42 & 0.75 & 0.96 & 0.39 & 0.85 \\
\hline Sample & $\begin{array}{l}\text { Total a } \\
{[€ 61 \mathrm{~m},}\end{array}$ & $\begin{array}{l}\text { ssets in } \\
€ 111 \mathrm{~m}]\end{array}$ & $\begin{array}{r}\text { Sale } \\
{[€ 50 \mathrm{~m},}\end{array}$ & $\begin{array}{l}\mathrm{s} \text { in } \\
€ 150 \mathrm{~m}]\end{array}$ & $\begin{array}{r}\text { Sal } \\
{[€ 50 \mathrm{~m}, €} \\
\text { total asse }\end{array}$ & $\begin{array}{l}\text { es in } \\
150 \mathrm{~m}] \& \\
\text { ts }>€ 86 \mathrm{~m}\end{array}$ & $\begin{array}{r}\text { Employ } \\
{[300,}\end{array}$ & $\begin{array}{l}\text { ment in } \\
700]\end{array}$ \\
\hline Firms & 5,888 & 5,888 & 7,101 & 7,101 & 2,085 & 2,085 & 4,526 & 4,526 \\
\hline
\end{tabular}

Panel B.

\begin{tabular}{|c|c|c|c|c|c|c|}
\hline & (1) & (2) & (3) & (4) & (5) & (6) \\
\hline Specification & First stage & Reduced form & IV & First stage & Reduced form & IV \\
\hline $\begin{array}{l}\text { Dependent variable } \\
\text { (2009-2011 average) }\end{array}$ & $\begin{array}{c}\text { R\&D exp. } \\
(£ \cdot 000)\end{array}$ & $\begin{array}{l}\text { All patent } \\
\text { count }\end{array}$ & $\begin{array}{c}\text { All patent } \\
\text { count }\end{array}$ & $\begin{array}{c}\text { R\&D exp. } \\
(\notin \cdot 000)\end{array}$ & $\begin{array}{c}\text { All patent } \\
\text { count }\end{array}$ & $\begin{array}{c}\text { All patent } \\
\text { count }\end{array}$ \\
\hline $\begin{array}{l}\text { Below asset threshold } \\
\text { dummy (in 2007) }\end{array}$ & $\begin{array}{c}87.3 \\
(59.1)\end{array}$ & $\begin{array}{c}0.114 * * * \\
(0.042)\end{array}$ & & $\begin{array}{l}73.6^{*} \\
(41.3)\end{array}$ & $\begin{array}{l}0.079 * * * \\
(0.026)\end{array}$ & \\
\hline $\begin{array}{l}\text { Below sales threshold } \\
\text { dummy (in 2007) }\end{array}$ & $\begin{array}{l}126.5^{*} \\
(66.4)\end{array}$ & $\begin{array}{c}0.032 \\
(0.050)\end{array}$ & & $\begin{array}{l}86.0 * * \\
(43.0)\end{array}$ & $\begin{array}{l}-0.005 \\
(0.024)\end{array}$ & \\
\hline $\begin{array}{l}\text { R\&D expenditure ( } £ \text { million), } \\
\text { 2009-11 average }\end{array}$ & & & $\begin{array}{l}0.698^{*} \\
(0.405)\end{array}$ & & & $\begin{array}{c}0.410 \\
(0.238)\end{array}$ \\
\hline Mean over 2006-08 & 105.3 & 0.083 & 0.083 & 98.1 & 0.071 & 0.071 \\
\hline Joint F-statistics (p-value) & $2.43(0.09)$ & $4.04(0.02)$ & & $2.52(0.08)$ & $5.47(0.00)$ & \\
\hline Sample & \multicolumn{3}{|c|}{ Sales in $[€ 50 \mathrm{~m}, € 150 \mathrm{~m}]$} & \multicolumn{3}{|c|}{$\begin{array}{l}\text { Total assets in }[€ 61 \mathrm{~m}, € 111 \mathrm{~m}] \\
\text { or sales in }[€ 60 \mathrm{~m}, € 140 \mathrm{~m}]\end{array}$} \\
\hline Firms & 7,091 & 7,091 & 7,091 & 8,120 & 8,120 & 8,120 \\
\hline
\end{tabular}

Note: $* * *$ significant at $1 \%$ level, $* * 5 \%$ level, * 10\% level. Robust standard errors are in brackets. Panel A: OLS estimates based on the RD design. The running variable in columns 1-2 is total assets in 2007 with threshold of $€ 86 \mathrm{~m}$. The running variable in columns 3-6 is sales in 2007 with threshold of $€ 100 \mathrm{~m}$. The running variable in columns 7-8 is employment in 2007 with threshold of 500. Controls for first order polynomials of running variable separately for each side of the threshold are included. Panel B: OLS estimates based on the RD design for first-stage and reduced-form regressions (columns 1-2 and 4-5). IV estimates based on the (fuzzy) RD design where the instrumental variable is the dummy whether total assets in 2007 is below $€ 86 \mathrm{~m}$ (columns 3 and 6). The running variables are total assets in 2007 with threshold of $€ 86 \mathrm{~m}$ and sales in 2007 with threshold of $€ 100 \mathrm{~m}$. Instrumental variable in columns 3 and 6 are the dummy whether total assets in 2007 is below $€ 86 \mathrm{~m}$ and the dummy whether sales in 2007 is below $€ 100 \mathrm{~m}$. Controls for first order polynomials of the running variable (total assets in 2007 and sales in 2007) separately for each side of the respective threshold are included. Reported joint F-statistics for are for below-assetthreshold dummy and below-sales-threshold dummy. 
Table A11. Tax-adjusted user cost of R\&D capital over time

\begin{tabular}{|c|c|c|c|c|c|c|c|}
\hline \multirow{3}{*}{ Tax relief scheme } & (1) & (2) & (3) & (4) & (5) & (6) & \multirow{3}{*}{$\begin{array}{c}\text { (7) } \\
\text { Log diff. in } \\
\text { user cost }\end{array}$} \\
\hline & \multicolumn{3}{|c|}{ SME } & \multicolumn{3}{|c|}{ Large company } & \\
\hline & Deduction & Payable credit & Average & Deduction & Payable credit & Average & \\
\hline 2006 & 0.157 & 0.152 & 0.154 & 0.179 & 0.200 & 0.190 & -0.210 \\
\hline 2007 & 0.157 & 0.152 & 0.154 & 0.179 & 0.200 & 0.190 & -0.210 \\
\hline 2008 & 0.147 & 0.151 & 0.149 & 0.177 & 0.200 & 0.190 & -0.238 \\
\hline 2009 & 0.142 & 0.151 & 0.147 & 0.177 & 0.200 & 0.190 & -0.255 \\
\hline 2010 & 0.142 & 0.151 & 0.147 & 0.177 & 0.200 & 0.190 & -0.255 \\
\hline 2011 & 0.130 & 0.150 & 0.141 & 0.179 & 0.200 & 0.191 & -0.302 \\
\hline $2006-2008$ & 0.154 & 0.152 & 0.153 & 0.178 & 0.200 & 0.190 & -0.219 \\
\hline 2009-2011 & 0.138 & 0.151 & 0.145 & 0.177 & 0.200 & 0.190 & -0.271 \\
\hline
\end{tabular}

Note: Tax-adjusted user cost of R\&D capital is calculated using formulae as described in sub-section 5.2. Corporate tax rate is $30 \%$ in 2006-07, 28\% in 2008-10, and 26\% in 2011. Enhancement rate is 50\% for SMEs and 25\% for large companies in 2006$08,75 \%$ for SMEs and 30\% for large companies in 2008-10, $100 \%$ for SMEs and 30\% for large companies in 2011. Payable credit rate is $16 \%$ in $2006-08,14 \%$ in $2008-10$, and $12.5 \%$ in 2011 . Share of the payable credit case is $55 \%$. Real interest rate is $5 \%$. Depreciation rate is $15 \%$. 
Table A12. Tax-price elasticity of R\&D investments using different approaches

\begin{tabular}{|c|c|c|c|c|c|c|}
\hline \multirow{2}{*}{\multicolumn{2}{|c|}{ Approach }} & \multicolumn{2}{|r|}{ (2) } & \multirow{2}{*}{$\begin{array}{l}\text { (3) } \\
\text { Log diff. in } \\
\text { R\&D }\end{array}$} & \multirow{2}{*}{$\begin{array}{l}\text { (4) } \\
\text { Log diff. in } \\
\text { user cost }\end{array}$} & \multirow{2}{*}{$\begin{array}{l}\text { (5) } \\
\text { Tax-price } \\
\text { elasticity }\end{array}$} \\
\hline & & $\begin{array}{l}\text { Treatment } \\
\text { effect }\end{array}$ & $\begin{array}{l}\text { Baseline } \\
\text { R\&D }\end{array}$ & & & \\
\hline \multirow[t]{2}{*}{1} & $\begin{array}{l}\text { Treatment effect: discontinuity in increase in average } \\
\text { R\&D expenditure } 3 \text {-year pre- compared to } 3 \text {-year post- } \\
\text { policy change Difference (After - Before) }\end{array}$ & $£ 75 \mathrm{k}$ & $£ 72 \mathrm{k}$ & 0.71 & -0.27 & -2.63 \\
\hline & $\begin{array}{l}\text { Baseline R\&D: average R\&D expenditure 3-year pre- } \\
\text { policy change } 2006-08\end{array}$ & & & & & \\
\hline \multirow[t]{2}{*}{2} & $\begin{array}{l}\text { Treatment effect: discontinuity in increase in average } \\
\text { R\&D expenditure } 3 \text {-year pre- compared to } 3 \text {-year post- } \\
\text { policy change Difference (After - Before) }\end{array}$ & $£ 75 \mathrm{k}$ & $£ 75 \mathrm{k}$ & 0.69 & -0.27 & -2.56 \\
\hline & $\begin{array}{l}\text { Baseline R\&D: average R\&D expenditure 2-year pre- } \\
\text { policy change } 2006-07\end{array}$ & & & & & \\
\hline \multirow[t]{2}{*}{3} & $\begin{array}{l}\text { Treatment effect: discontinuity in average R\&D } \\
\text { expenditure over 2009-11, controlling for R\&D in } 2007\end{array}$ & $£ 75 \mathrm{k}$ & $£ 47 \mathrm{k}$ & 0.95 & -0.27 & -3.51 \\
\hline & $\begin{array}{l}\text { Baseline R\&D: predicted average } R \& D \text { expenditure over } \\
2009-11 \text { by a large company at the asset threshold } € 86 \mathrm{~m}\end{array}$ & & & & & \\
\hline 4 & $\begin{array}{l}\text { Specification: Poisson regression } \\
\text { Treatment effect: discontinuity in average R\&D } \\
\text { expenditure over 2009-11, controlling for R\&D in } 2007\end{array}$ & & & 1.08 & -0.27 & -3.97 \\
\hline \multirow[t]{2}{*}{5} & $\begin{array}{l}\text { Sample: firms with total assets in } 2007 \text { in }[€ 66 \mathrm{~m}, € 106 \mathrm{~m}] \\
\text { Treatment effect: discontinuity in increase in average } \\
\text { R\&D expenditure } 3 \text {-year pre- compared to } 3 \text {-year post- } \\
\text { policy change Difference(After - Before) }\end{array}$ & $£ 288 \mathrm{k}$ & $£ 73 \mathrm{k}$ & 0.79 & -0.27 & -2.91 \\
\hline & $\begin{array}{l}\text { Baseline R\&D: average R\&D expenditure 3-year pre- } \\
\text { policy change } 2006-08\end{array}$ & & & & & \\
\hline \multirow[t]{3}{*}{6} & $\begin{array}{l}\text { Treatment effect: discontinuity in increase in average } \\
\text { R\&D expenditure } 3 \text {-year pre- compared to } 3 \text {-year post- } \\
\text { policy change Difference (After - Before) }\end{array}$ & $£ 75 \mathrm{k}$ & $£ 72 \mathrm{k}$ & 0.71 & -0.23 & -3.11 \\
\hline & $\begin{array}{l}\text { Baseline R\&D: average R\&D expenditure 3-year pre- } \\
\text { policy change } 2006-08\end{array}$ & & & & & \\
\hline & $\begin{array}{l}\text { Tax-adjusted user cost of R\&D capital: calculated using } \\
\text { small profit rate instead of main rate for corporate tax rate }\end{array}$ & & & & & \\
\hline
\end{tabular}

Note: $\log$ difference in $R \& D$ investments is calculated as $\ln ($ treatment effect + baseline $R \& D)-\ln ($ baseline $R \& D)$. Tax-price elasticity of $R \& D$ is calculated as $\frac{\ln (\text { difference in } R \& D \text { investments })}{\ln \text { (difference in user cost of } R \& D \text { capital })}$. Baseline sample includes firms with total assets in 2007 in in $[€ 61 \mathrm{~m}, € 111 \mathrm{~m}]$ unless indicated otherwise. Treatment effect used in approaches 1,2 and 6 is reported in column 9 of Table 2. Treatment effects used in approaches 3 and 4 are reported in columns 4 and 9 of Table A3 Panel A respectively. Treatment effect used in approach 5 is estimated using same specification as in column 9 of Table 2 for the specified sample. Approaches 1 to 5 use the baseline log difference in tax-adjusted user cost of R\&D capital between SMEs and large companies as estimated in sub-section 5.2 and reported in Table A12. Approach 6 uses the same formulae as described in subsection 5.2 to calculate log difference in tax-adjusted user cost of R\&D capital, but using small profit rate $(20 \%$ in $2006-07,21 \%$ in $2008-10$, and $20 \%$ in 2011) instead of main rate for corporate tax rate. 
Table A13. Value for money analysis of R\&D Tax Relief Scheme

\begin{tabular}{|c|c|c|c|c|c|c|c|}
\hline & 2006 & 2007 & 2008 & 2009 & 2010 & 2011 & $\begin{array}{l}\text { Average } \\
\text { 2006-11 }\end{array}$ \\
\hline \multicolumn{8}{|l|}{ Panel A: Policy parameters } \\
\hline SME enhancement rate $e_{S M E}$ & $50 \%$ & $50 \%$ & $67 \%$ & $75 \%$ & $75 \%$ & $100 \%$ & \\
\hline SME payable credit rate $c_{S M E}$ & $16 \%$ & $16 \%$ & $15 \%$ & $14 \%$ & $14 \%$ & $12.5 \%$ & \\
\hline SME effective corporate tax rate $\tau_{S M E}$ & $19 \%$ & $19 \%$ & $21 \%$ & $21 \%$ & $21 \%$ & $20 \%$ & \\
\hline LCO enhancement rate $e_{L C O}$ & $25 \%$ & $25 \%$ & $30 \%$ & $30 \%$ & $30 \%$ & $30 \%$ & \\
\hline LCO effective corporate tax rate $\tau_{L C O}$ & $30 \%$ & $30 \%$ & $28 \%$ & $28 \%$ & $28 \%$ & $26 \%$ & \\
\hline \multicolumn{8}{|l|}{ Panel B: SME tax deduction case } \\
\hline Tax-adjusted user cost of R\&D & 0.177 & 0.177 & 0.165 & 0.160 & 0.160 & 0.150 & \\
\hline Value for money ratio $\Delta_{R D} / \Delta_{E C}$ & 2.944 & 2.944 & 2.866 & 2.811 & 2.811 & 2.654 & 2.791 \\
\hline Exchequer costs $(£ m)$ & 50 & 60 & 80 & 130 & 160 & 210 & 115 \\
\hline Additional R\&D (£m) & 147 & 177 & 229 & 365 & 450 & 557 & 321 \\
\hline \multicolumn{8}{|l|}{ Panel C: SME payable tax credit case } \\
\hline Tax-adjusted user cost of R\&D & 0.152 & 0.152 & 0.151 & 0.151 & 0.151 & 0.150 & \\
\hline Value for money ratio $\Delta_{R D} / \Delta_{E C}$ & 2.142 & 2.142 & 2.134 & 2.133 & 2.133 & 2.123 & 2.134 \\
\hline Exchequer costs $(£ m)$ & 150 & 180 & 190 & 190 & 190 & 220 & 187 \\
\hline Additional R\&D (£m) & 321 & 386 & 405 & 405 & 405 & 467 & 398 \\
\hline \multicolumn{8}{|c|}{ Panel D: Large company tax deduction case } \\
\hline Tax-adjusted user cost of R\&D & 0.179 & 0.179 & 0.177 & 0.177 & 0.177 & 0.179 & \\
\hline Value for money ratio $\Delta_{R D} / \Delta_{E C}$ & 1.429 & 1.429 & 1.389 & 1.389 & 1.389 & 1.351 & 1.392 \\
\hline Exchequer costs $(£ m)$ & 480 & 550 & 730 & 670 & 750 & 780 & 660 \\
\hline Additional R\&D by LCOs $(£ m)$ & 686 & 786 & 1,014 & 931 & 1,042 & 1,054 & 919 \\
\hline \multicolumn{8}{|l|}{ Panel D: Aggregates } \\
\hline Total Exchequer costs $(£ m)$ & 680 & 790 & 1,000 & 990 & 1,100 & 1,210 & 962 \\
\hline Total additional R\&D (£m) & 1,154 & 1,348 & 1,649 & 1,701 & 1,897 & 2,078 & 1,638 \\
\hline Value for money ratio & 1.697 & 1.706 & 1.649 & 1.718 & 1.724 & 1.718 & 1.703 \\
\hline Total qualifying R\&D ( $£ m$ ) & 7,670 & 8,880 & 10,800 & 9,730 & 10,880 & 11,840 & 9,967 \\
\hline Fall of aggregate $R \& D$ without policy & $15 \%$ & $15 \%$ & $15 \%$ & $17 \%$ & $17 \%$ & $18 \%$ & $16 \%$ \\
\hline
\end{tabular}

Note: Tax-adjusted user cost of R\&D and value for money ratio are calculated using the formulae as described in Appendix A5 using the above policy parameters. In addition, real interest rate is $5 \%$ and depreciation rate is $15 \%$. Tax-adjusted user cost of $\mathrm{R} \& \mathrm{D}$ without any tax relief is calculated to be 0.200 . Tax-price elasticity of R\&D among SMEs is -2.63 as estimated in subsection 5.2. Tax-price elasticity of R\&D among large companies is -1.00. Exchequer costs come from HMRC national statistics. Additional R\&D is calculated as value for money ratios times Exchequer costs. 
$\underline{\text { Table B1 Descriptive Statistics }}$

Panel A. Full CT600 dataset

\begin{tabular}{|c|c|c|c|c|c|c|c|c|}
\hline & Unit & 2006 & 2007 & 2008 & 2009 & 20210 & 2011 & 2006-11 \\
\hline No. of firms & Firm & $1,406,696$ & $1,487,173$ & $1,484,311$ & $1,504,927$ & $1,564,871$ & $1,646,641$ & $2,495,944$ \\
\hline No. of firms claiming $R \& D$ relief & Firm & 6,431 & 7,429 & 8,334 & 9,144 & 10,150 & 12,003 & 20,730 \\
\hline \multicolumn{9}{|l|}{ SME Scheme } \\
\hline No. of firms claiming & Firm & 5,153 & 5,855 & 6,570 & 7,354 & 8,238 & 9,921 & 20,205 \\
\hline Avg. qual. R\&D expenditure & $£($ nom $)$ & 257,752 & 268,904 & 266,730 & 244,854 & 263,811 & 258,541 & $1,569,728$ \\
\hline Avg. estimated Exchequer costs & $£($ nom $)$ & 39,433 & 42,150 & 41,018 & 44,099 & 43,138 & 43,451 & 169,643 \\
\hline \multicolumn{9}{|l|}{ Large Company Scheme } \\
\hline No. of firms claiming & Firm & 1,290 & 1,592 & 1,776 & 1,795 & 1,923 & 2,092 & 4,048 \\
\hline Avg. qual. R\&D expenditure & $£($ nom $)$ & $4,926,939$ & $4,616,811$ & $5,120,979$ & $4,435,308$ & $4,508,202$ & $4,357,442$ & $12,580,710$ \\
\hline Avg. estimated Exchequer costs & $£($ nom $)$ & 371,097 & 346,616 & 412,088 & 376,405 & 382,284 & 357,870 & $1,030,878$ \\
\hline \multicolumn{9}{|l|}{ SME subcontractors } \\
\hline No. of firms claiming & Firm & 399 & 443 & 522 & 610 & 720 & 715 & 2,100 \\
\hline Avg. qual. R\&D expenditure & $£($ nom $)$ & 630,098 & 465,590 & 406,302 & 504,624 & 658,942 & 928,208 & $1,007,468$ \\
\hline Avg. estimated Exchequer costs & $£($ nom $)$ & 47,406 & 48,014 & 43,043 & 42,618 & 46,771 & 56,809 & 315,560 \\
\hline \multicolumn{9}{|l|}{ Patenting } \\
\hline No. of firms having patents & Firm & 3,093 & 3,085 & 2,965 & 2,806 & 2,682 & 2,662 & 9,420 \\
\hline Avg. number of patents & Patent & 2.68 & 2.77 & 2.72 & 2.63 & 2.66 & 2.64 & 4.93 \\
\hline No. of firms having UK patents & Firm & 3,262 & 3,316 & 3,228 & 3,083 & 2,989 & 2,965 & 8,986 \\
\hline Avg. number of UK patents & Patent & 3.00 & 3.08 & 3.00 & 2.83 & 2.78 & 2.82 & 6.13 \\
\hline No. of firms having EPO patents & Firm & 1,453 & 1,448 & 1,376 & 1,409 & 1,358 & 1,125 & 4.770 \\
\hline Avg. number of EPO patents & Patent & 0.95 & 0.90 & 0.82 & 0.83 & 0.47 & 0.17 & 4.95 \\
\hline
\end{tabular}

Panel B. Full FAME dataset

\begin{tabular}{|c|c|c|c|c|c|c|c|c|}
\hline & Unit & 2006 & 2007 & 2008 & 2009 & 20210 & 2011 & 2006-11 \\
\hline No. of firms & Firm & $1,780,531$ & $1,858,209$ & $1,870,089$ & $1,898,721$ & $1,973,722$ & $2,073,930$ & $3,140,060$ \\
\hline \multicolumn{9}{|l|}{ Variable coverage } \\
\hline No. of firms with total assets & Firm & $1,732,169$ & $1,807,743$ & $1,818,448$ & $1,843,896$ & $1,914,848$ & $2,015,058$ & $3,012,397$ \\
\hline Total assets coverage & $\%$ & $97.3 \%$ & $97.3 \%$ & $97.2 \%$ & $97.1 \%$ & $97.0 \%$ & $97.2 \%$ & $95.9 \%$ \\
\hline No. of firms with sales & Firm & 352,680 & 319,726 & 275,938 & 274,768 & 263,394 & 227,463 & 626,025 \\
\hline Sales coverage & $\%$ & $19.8 \%$ & $17.2 \%$ & $14.8 \%$ & $14.5 \%$ & $13.3 \%$ & $11.0 \%$ & $19.9 \%$ \\
\hline No. of firms with employment & Firm & 95,615 & 93,855 & 91,375 & 94,332 & 98,426 & 97,814 & 164,849 \\
\hline Employment coverage & $\%$ & $5.4 \%$ & $5.1 \%$ & $4.9 \%$ & $5.0 \%$ & $5.0 \%$ & $4.7 \%$ & $5.2 \%$ \\
\hline
\end{tabular}

\section{Panel C. CT600 and FAME matching}

\begin{tabular}{|c|c|c|c|c|c|c|c|c|}
\hline & Unit & 2006 & 2007 & 2008 & 2009 & 20210 & 2011 & 2006-11 \\
\hline $\begin{array}{l}\text { \# of CT600 firms that appear in } \\
\text { FAME between } 2006 \text { and } 2011\end{array}$ & Firm & $1,353,844$ & $1,427,132$ & $1,442,619$ & $1,468,000$ & $1,529,317$ & $1,598,012$ & $2,358,948$ \\
\hline As share of CT600 firm count & $\%$ & $96.2 \%$ & $96.0 \%$ & $97.2 \%$ & $97.5 \%$ & $97.7 \%$ & $97.0 \%$ & $94.5 \%$ \\
\hline \multicolumn{9}{|l|}{ Out of which } \\
\hline \# of firms claiming tax relief & Firm & 6,411 & 7,409 & 8,298 & 9,105 & 10,108 & 11,937 & 20,627 \\
\hline As share of CT600 R\&D firms & $\%$ & $99.7 \%$ & $99.7 \%$ & $99.6 \%$ & $99.6 \%$ & $99.6 \%$ & $99.5 \%$ & $99.5 \%$ \\
\hline \# of firms having patents & Firm & 3,078 & 3,065 & 2,951 & 2,789 & 2,665 & 2,634 & 9,376 \\
\hline \multicolumn{2}{|c|}{ As share of CT600 patenting firms $\%$} & $99.5 \%$ & $99.4 \%$ & $99.5 \%$ & $99.4 \%$ & $99.4 \%$ & $98.9 \%$ & $99.5 \%$ \\
\hline
\end{tabular}

Note: Average qualifying R\&D expenditure and estimated Exchequer costs are calculated for corresponding R\&D-tax-relief claiming firms. Average number of patents, UK patents, and EPO patents are calculated for corresponding patenting firms. 


\section{Figure A1. Discontinuities in average R\&D expenditure over 2009-11 at "pseudo" SME asset thresholds}

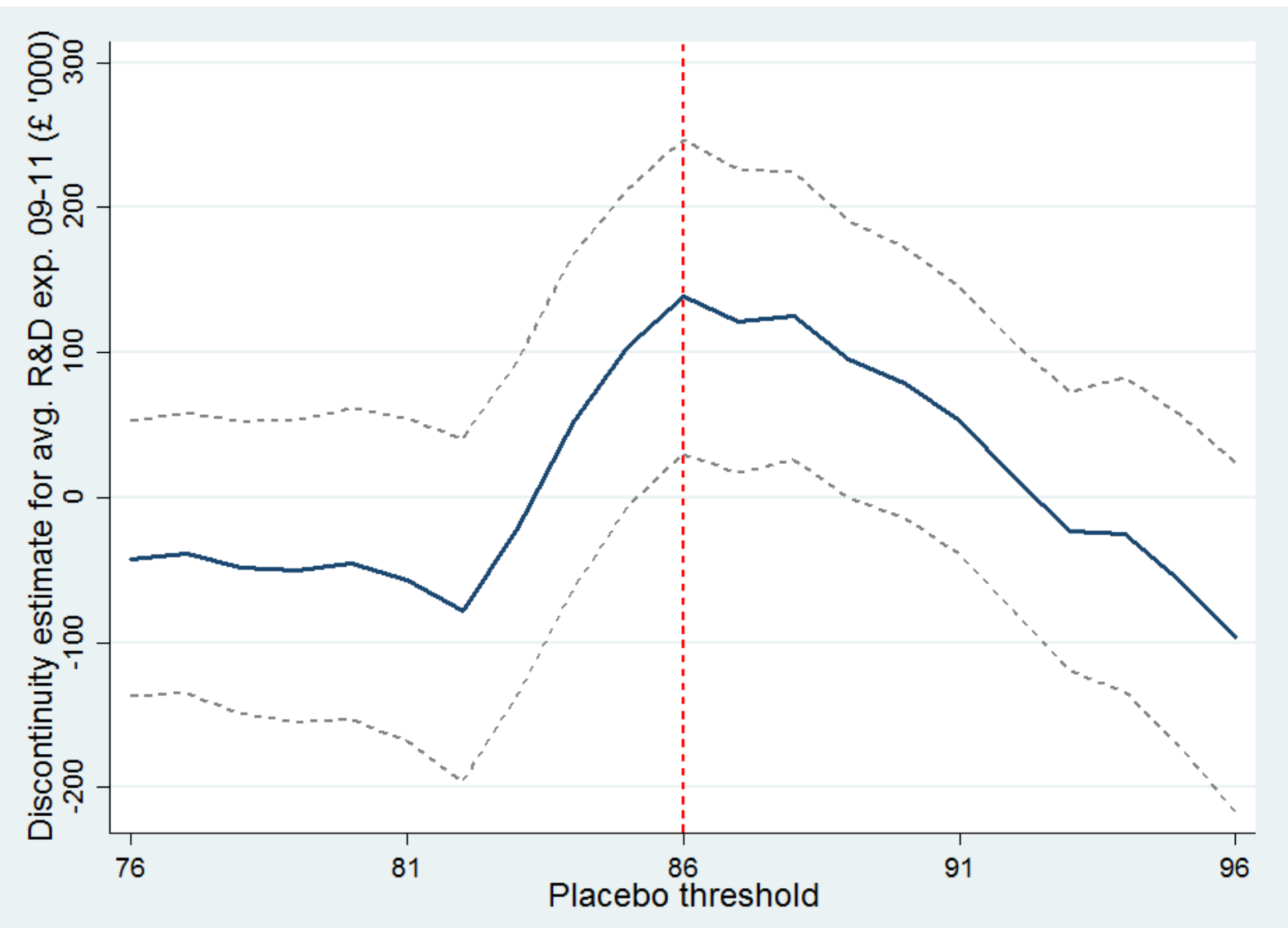

Note: Discontinuity estimate at each placebo threshold is estimated using the baseline first-stage R\&D expenditure regression (OLS Regression Discontinuity Design (RDD) with average R\&D expenditure over 2009-11 as the dependent variable).The running variable is total assets in 2007. Baseline sample includes firms with total assets in $2007 € 25 \mathrm{~m}$ above and below the placebo threshold. Controls for first order polynomials of running variable separately for each side of the placebo threshold are included. The dashed lines indicate the $95 \%$ confidence interval for the discontinuity estimates. 


\section{Figure A2. Discontinuities in average number of patents over 2009-11 at "pseudo" SME asset thresholds}

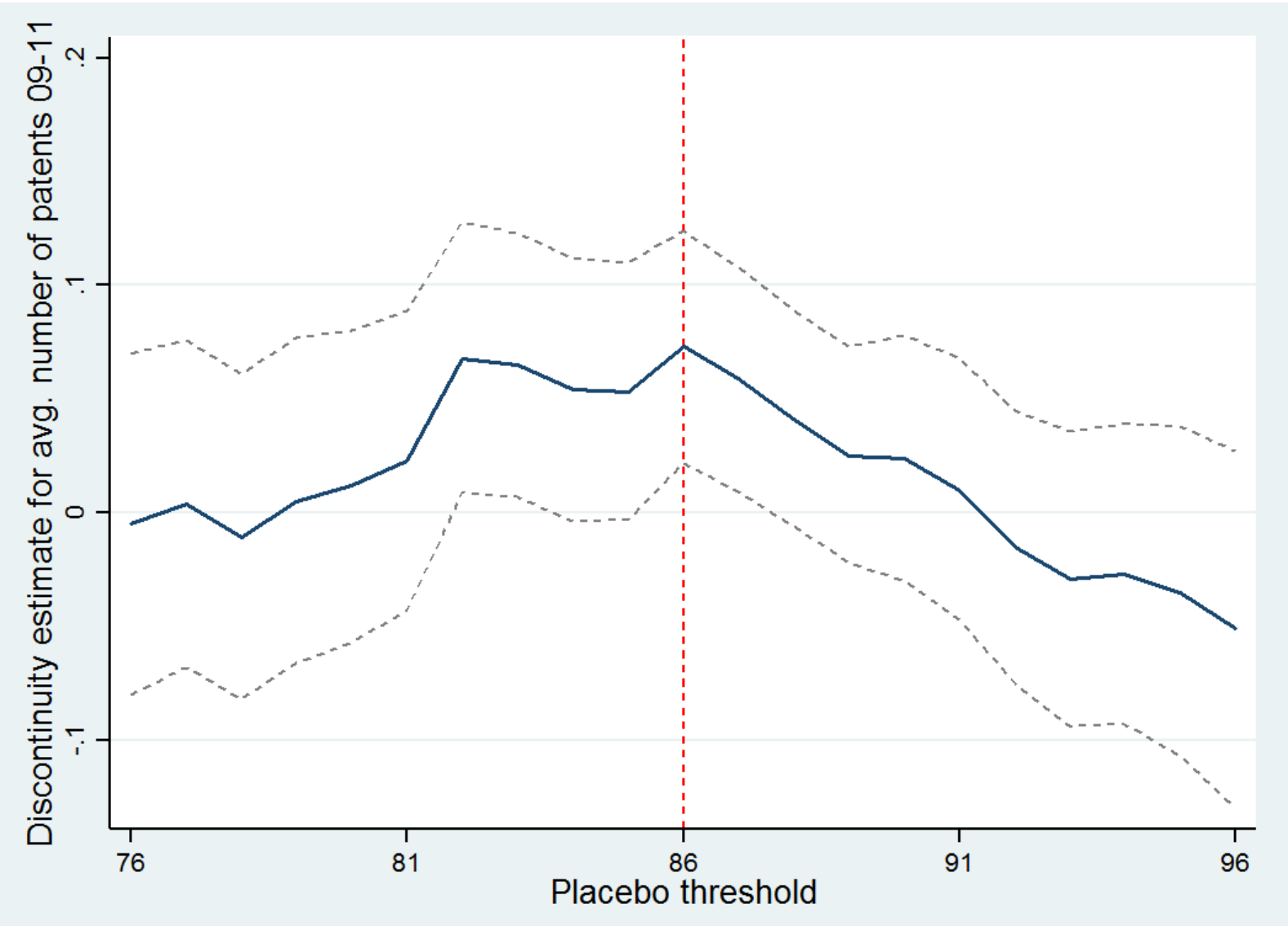

Note: Discontinuity estimate at each placebo threshold is estimated using the baseline reduced-form $R \& D$ expenditure regression (OLS estimates based on the RD design with average number of patents over 2009-11 as the dependent variable).The running variable is total assets in 2007. Baseline sample includes firms with total assets in $2007 € 25 \mathrm{~m}$ above and below the placebo threshold. Controls for first order polynomials of running variable separately for each side of the placebo threshold are included. The dashed lines indicate the $95 \%$ confidence interval for the discontinuity estimates. 
Figure A3. McCrary tests for no manipulation at the SME asset threshold, year-by-year
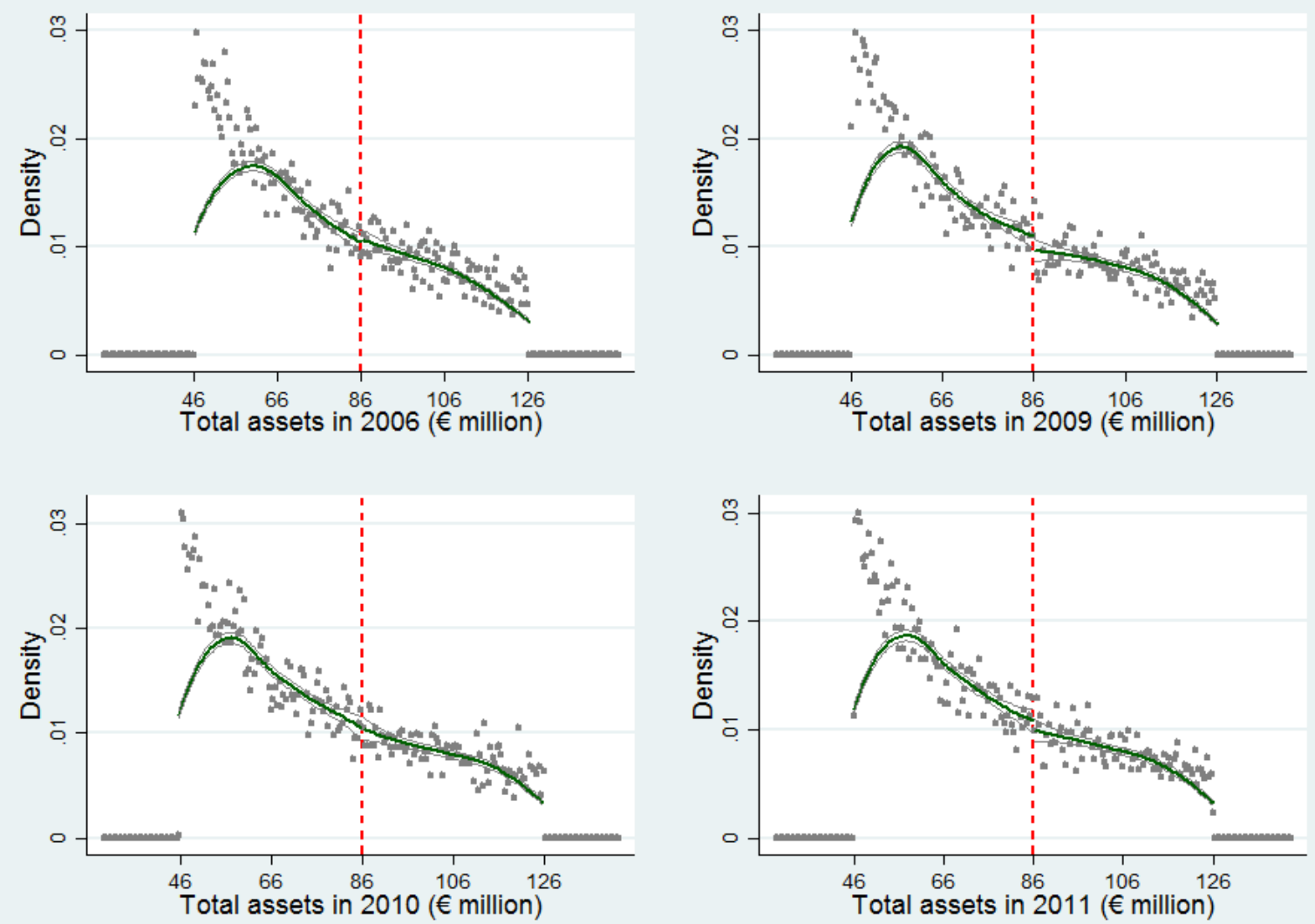

Note: McCrary tests for discontinuity in distribution density of total assets at the SME asset threshold of $€ 86 \mathrm{~m}$, year-by-year for 2006, 2009, 2010, and 2011. Each sample includes firms with total assets in [€46m, €126m] in the respective year. The discontinuity estimate (log difference in density height at the SME threshold) (standard error) in 2006 is $0.029(0.065)$, in 2009 is -0.125 (0.078), in 2010 is $-0.006(0.077)$, and in 2011 is $-0.086(0.075)$. 
Figure A4. McCrary test for no manipulation at the SME asset threshold before the policy change

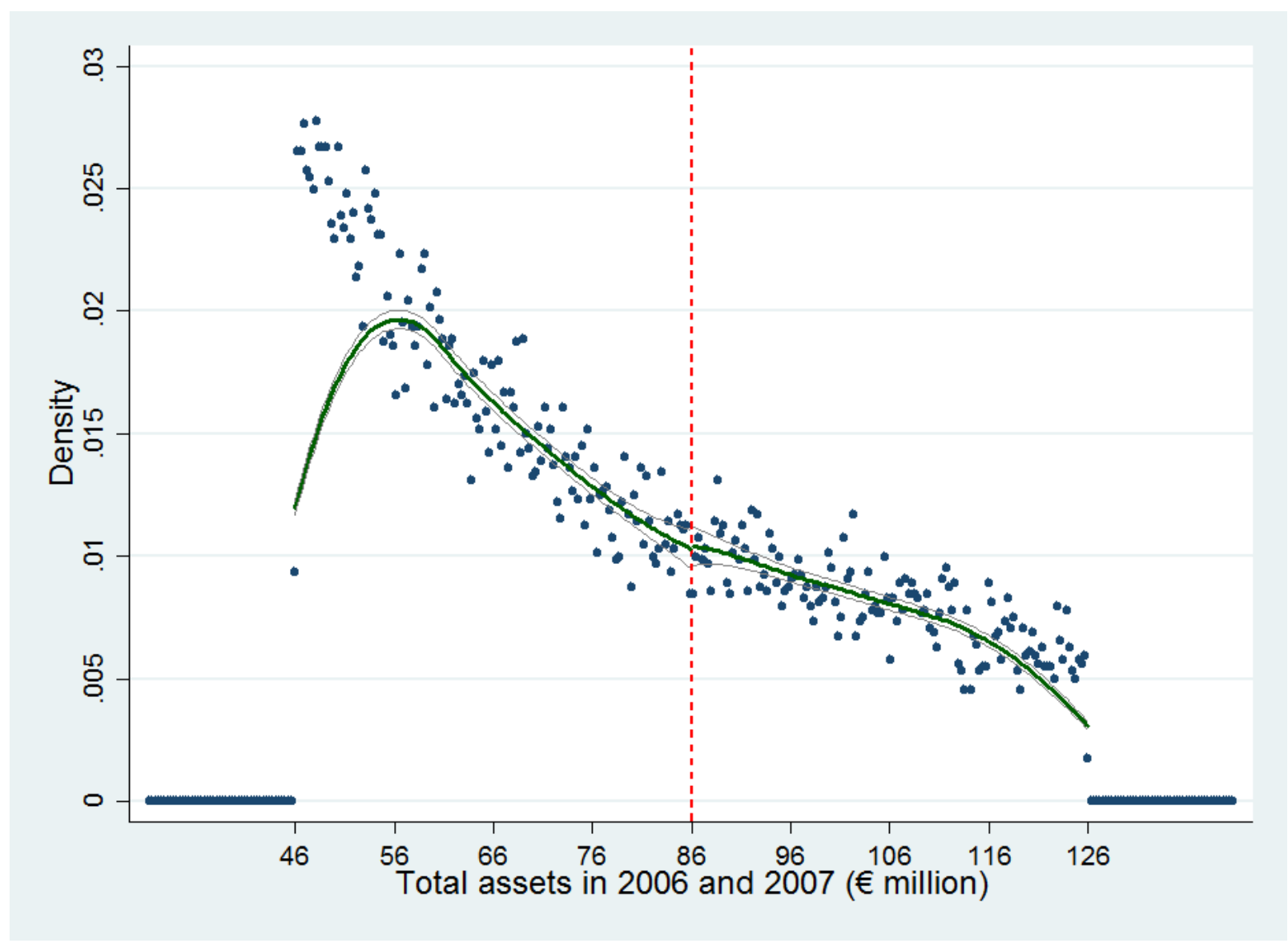

Note: McCrary test for discontinuity in distribution density of total assets at the SME asset threshold of $€ 86 \mathrm{~m}$ before the policy change, pooling together total assets in 2006 and 2007. Sample includes firms with total assets in [€46m, $€ 126 \mathrm{~m}]$ in each of the year. The discontinuity estimate (log difference in density height at the SME threshold) is 0.013 , with standard error of 0.056 . 
Figure A5. McCrary test for no manipulation at the SME asset threshold after the policy change

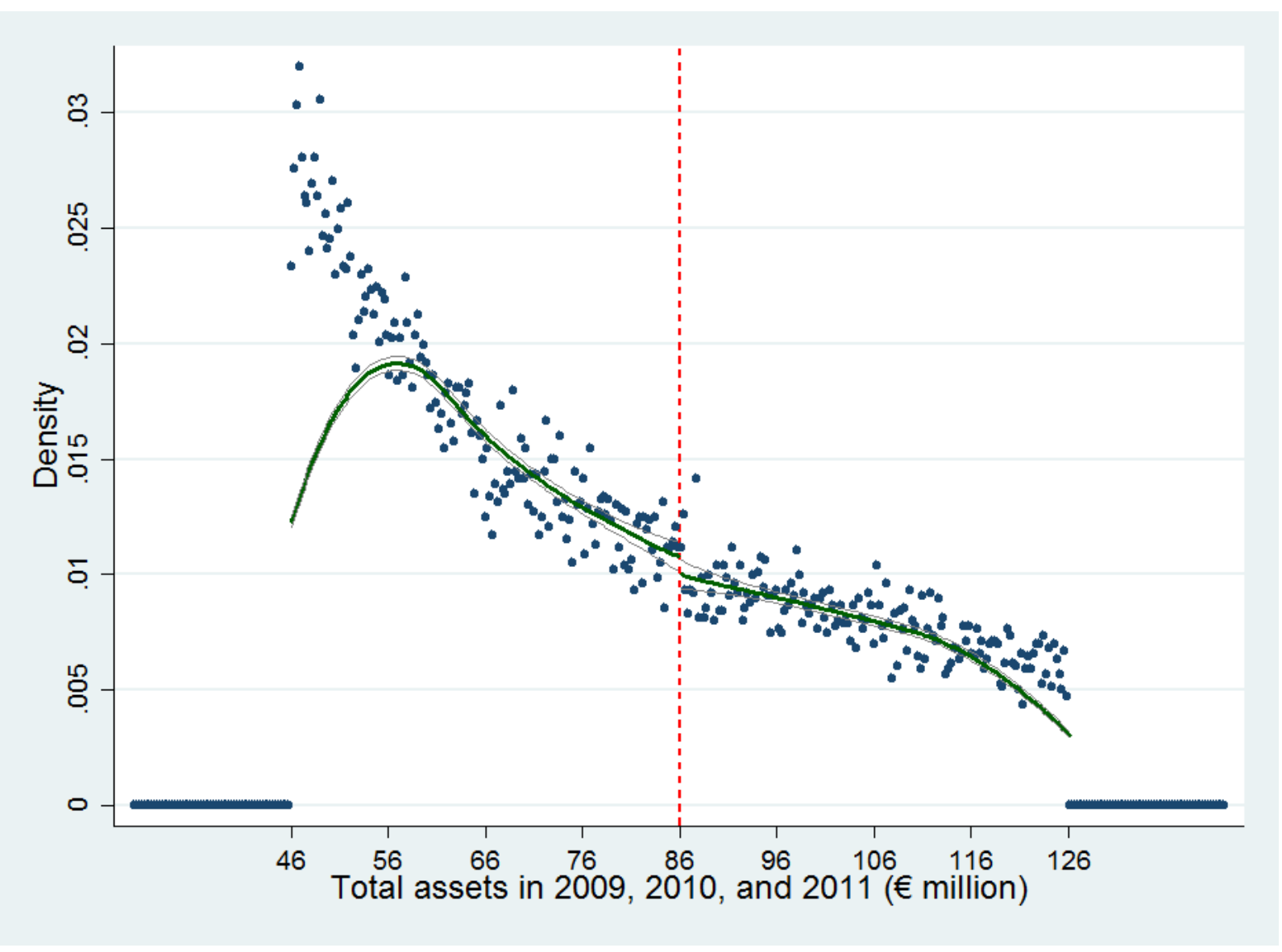

Note: McCrary test for discontinuity in distribution density of total assets at the SME asset threshold of $€ 86 \mathrm{~m}$ after the policy change, pooling together total assets in 2009, 2010, and 2011. Sample includes firms with total assets in $[€ 46 \mathrm{~m}, € 126 \mathrm{~m}]$ in each of the year. The discontinuity estimate (log difference in density height at the SME threshold) is -0.072 , with standard error of 0.045 . 
Figure A6. Number of firms with binding and not-binding asset and revenue thresholds

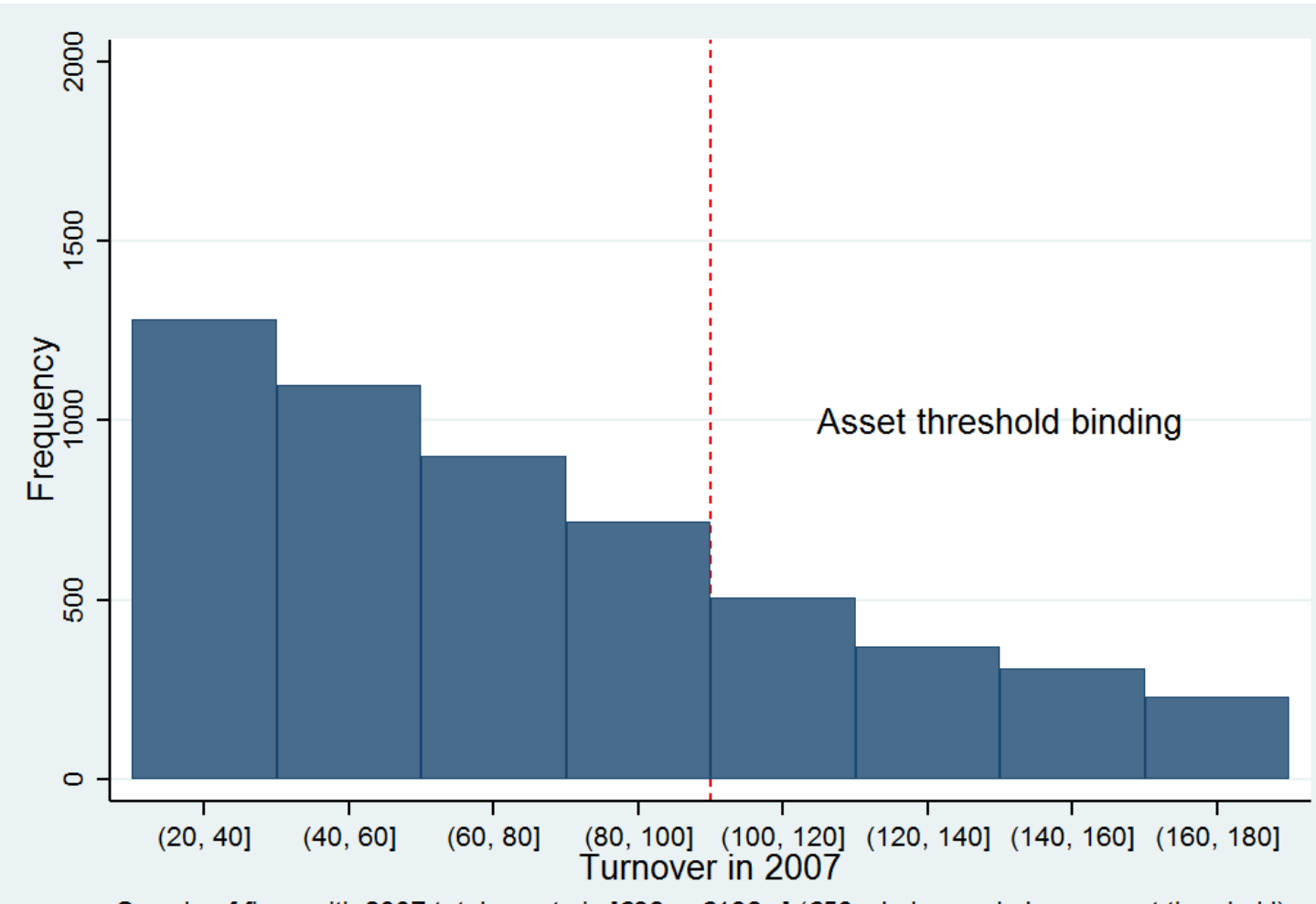

Sample of firms with 2007 total assets in [ $€ 36 \mathrm{~m}, € 136 \mathrm{~m}$ ] ( $€ 50 \mathrm{~m}$ below and above asset threshold) $\mathrm{N}$ not binding $=3,998 ; \mathrm{N}$ binding $=1,419 ;$ Fraction binding $/$ not binding $=0.355$

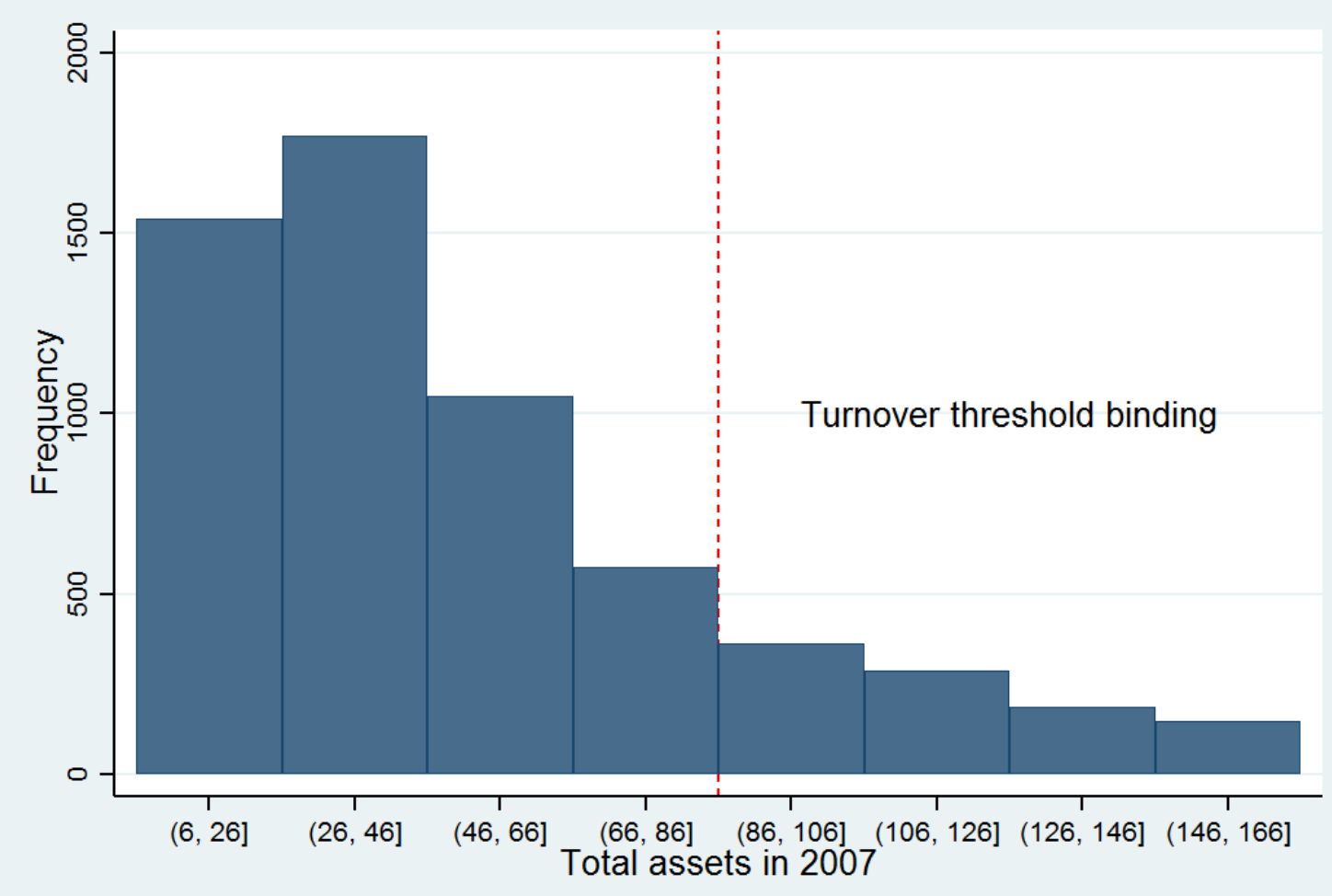

Sample of firms with 2007 turnover in [ $€ 50 \mathrm{~m}, € 150 \mathrm{~m}]$ ( $€ 50 \mathrm{~m}$ below amd above turnover threshold) $\mathrm{N}$ not binding $=4,934 ; \mathrm{N}$ binding $=983 ;$ Fraction binding $/$ not binding $=0.200$

Note: Asset threshold is not binding for firms with 2007 sales in $(€ 20 \mathrm{~m}, € 100 \mathrm{~m}]$ and binding for firms with 2007 sales in $(€ 100 \mathrm{~m}, € 180 \mathrm{~m}]$. Sales threshold is not binding for firms with 2007 total assets in $(€ 6 \mathrm{~m}, € 86 \mathrm{~m})$ and binding for firms with 2007 total assets in $(€ 86 \mathrm{~m}, € 166 \mathrm{~m})$. 